\title{
Salt Marsh Dieback in Coastal Louisiana: Survey of Plant and Soil Conditions in Barataria and Terrebonne Basins, June 2000-September 2001
}

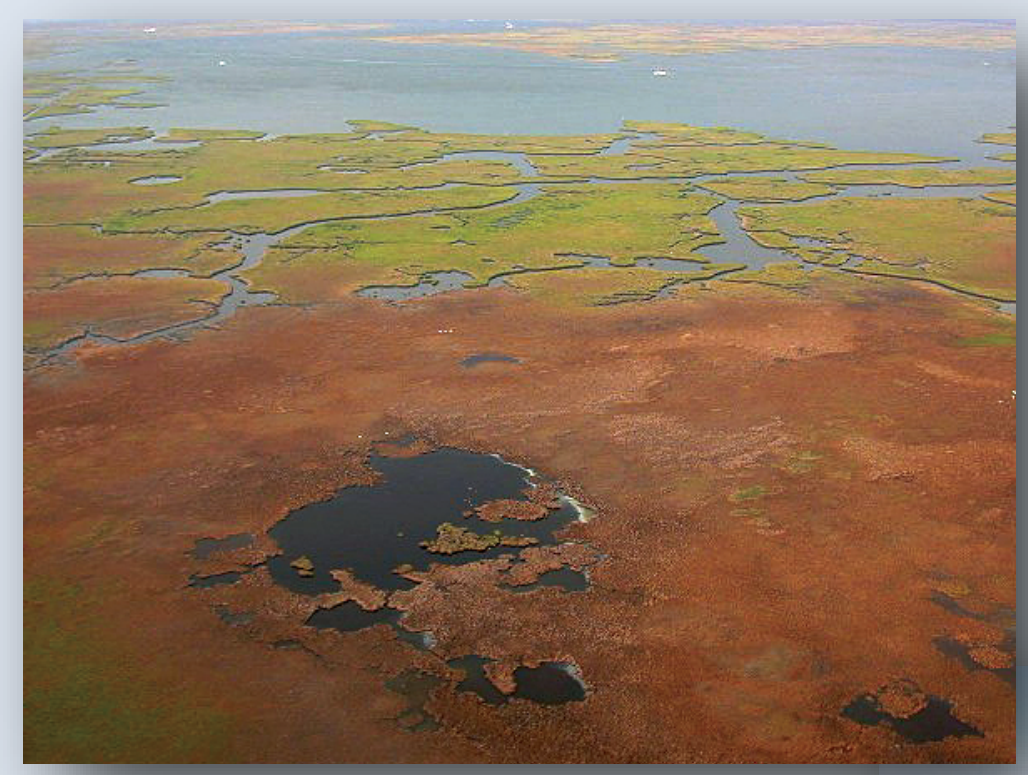

Open-File Report 2006-1167

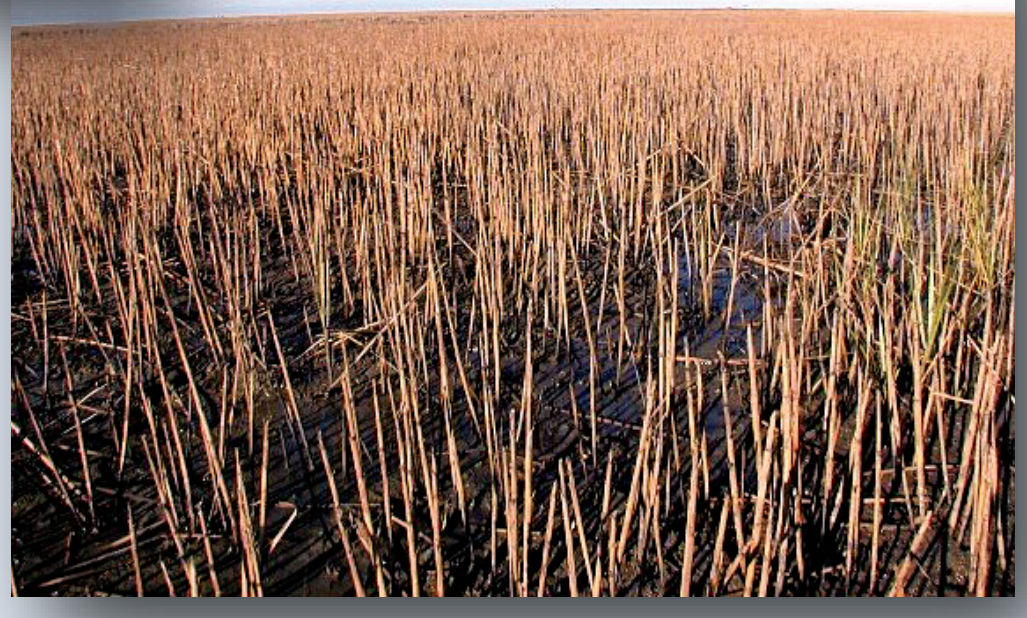

U.S. Department of the Interior U.S. Geological Survey 


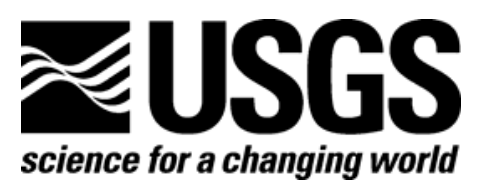

\section{Salt Marsh Dieback in Coastal Louisiana: Survey of Plant and Soil Conditions in Barataria and Terrebonne Basins, June 2000-September 2001}

By Karen L. McKee, Irving A. Mendelssohn, and Michael D. Materne

Open-File Report 2006-1167

U.S. Department of the Interior

U.S. Geological Survey 


\section{U.S. Department of the Interior DIRK KEMPTHORNE, Secretary}

\section{U.S. Geological Survey \\ P. Patrick Leahy, Acting Director}

\section{U.S. Geological Survey, Reston, Virginia 2006}

For product and ordering information:

World Wide Web: http://www.usgs.gov/pubprod

Telephone: 1-888-ASK-USGS

For more information on the USGS - the Federal source for science about the Earth, its natural and living resources, natural hazards, and the environment:

World Wide Web: http://www.usgs.gov

Telephone: 1-888-ASK-USGS

Suggested citation:

McKee, K.L., Mendelssohn, I.A., and Materne, M.D., 2006, Salt marsh dieback in coastal Louisiana: Survey of plant and soil conditions in Barataria and Terrebonne Basins, June 2000-September 2001: U.S. Geological Survey Open File Report 2006-1167. 71 pp.

Any use of trade, product, or firm names is for descriptive purposes only and does not imply endorsement by the U.S. Government.

Although this report is in the public domain, permission must be secured from the individual copyright owners to reproduce any copyrighted material contained within this report. 


\section{Contents}

List of Figures..................................................................................

List of Tables....................................................................................... viii

Executive Summary ...................................................................................

Biotic Agents....................................................................................... 2

Excessive Soil Waterlogging and Sulfide....................................... 2

Drought and Low Water Levels...................................................

Direct Lack of Water...........................................................

Hypersalinity..................................................................... 3

Soil Acidification and Metal Toxicity.................................... 3

Abstract

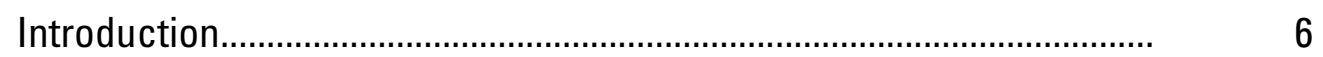

Study Sites and Experimental Design.........................................................

Preliminary Survey at Bay Junop.........................................................

Intensive Survey across Terrebonne and Barataria Basins......... 7

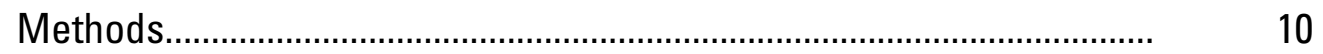

Vegetative Condition....................................................................... 10

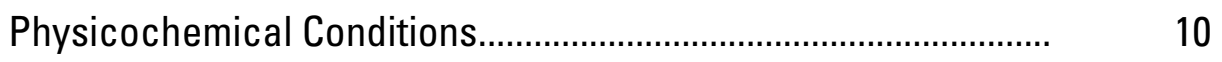

Leaf and Soil Elemental Concentrations.......................................... 12

Soil Acidification Potential..................................................................... 12

Statistical Analyses..................................................................

Results and Discussion...........................................................................

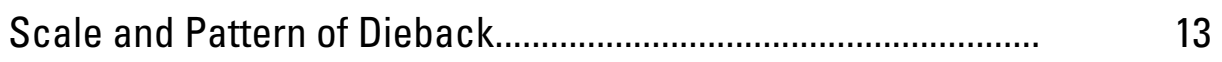

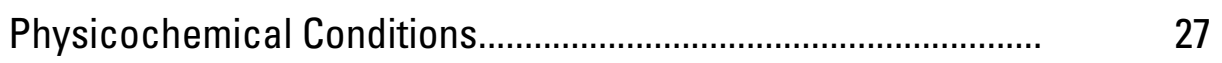


Bay Junop..................................................................

Intensive Sites 1-21 ............................................................. 27

Soil Elemental Concentrations............................................................ 27

Soil Acidification Potential.................................................................. 38

Plant Elemental Concentrations.................................................... 38

Vegetative Recovery........................................................................ 51

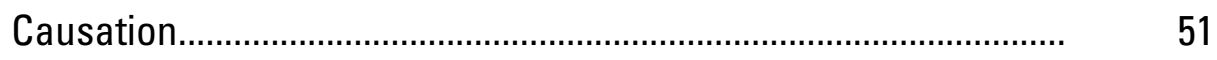

Hypothesis 1 ................................................................

Hypothesis 2 ……………………………………....

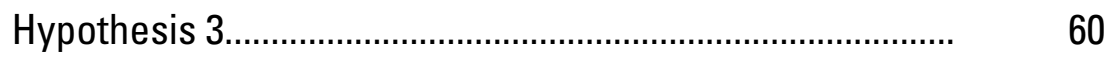

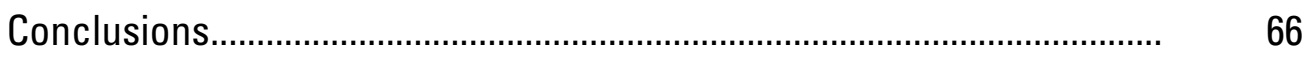

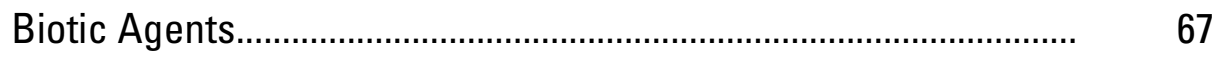

Excessive Soil Waterlogging and Sulfide............................................ 67

Drought and Low Water Levels.......................................................... 67

Direct Lack of Water....................................................... 67

Hypersalinity.................................................................... 68

Soil Acidification and Metal Toxicity...................................... 68

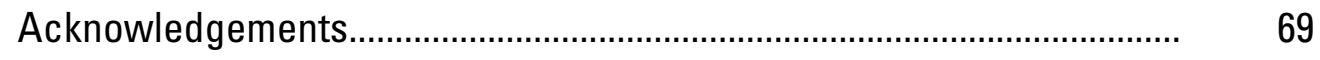

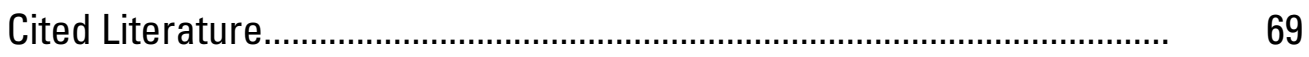




\section{Figures}

Figure 1. Map of study area and location of study sites..................................... 8

Figure 2. Experimental design for intensive survey.............................................. 9

Figure 3. Views of dieback site at Bay Junop in June 2000............................... 14

Figure 4. Aerial and ground views of a dieback Spartina patens marsh in August 2000

Figure 5. Spatial patterns of marsh dieback....................................................... 18

Figure 6. Ground views of healthy shoreline and dieback interior stands of Spartina alterniflora in August 2000............................................ 19

Figure 7. Relative cover by condition measured in the shoreline zone at sites 1-21 in August/0ctober 2000, April 2001, and September 2001...... 20

Figure 8. Relative cover by condition measured in the transition zone at sites 1-21 in August/October 2000, April 2001, and September 2001....... 21

Figure 9. Relative cover by condition measured in the interior zone at sites 1-21 in August/October 2000, April 2001, and September 2001....... 22

Figure 10. Viability of Spartina alterniflora rhizomes

in August-October 2000 ................................................................................

Figure 11. Aerial view of Pelican Island showing healthy Avicennia germinans stands alongside dying Spartina alterniflora marsh...................................... 25

Figure 12. Aerial and ground views of Juncus roemerianus (black needlerush) patches growing within areas of dead Spartina alterniflora (smooth cordgrass) .................................................................. 26

Figure 13. Soil conditions measured at Bay Junop in June 2000........................ 28

Figure 14. Soil redox potential measured in shoreline, transition, and interior zones at dieback sites. 
Figure 15. Soil salinity, pH, and sulfide measured in shoreline, transition, and interior zones at dieback sites

Figure 16. Acid-extractable Al and Fe concentrations in different vegetation zones in April 2001

Figure 17. Soil pyrite concentrations in different vegetation zones in August 2000.

Figure 18. Acidification potential of soils from dieback and control marshes.

Figure 19. Leaf elemental ratios in Spartina alterniflora growing in dieback and control marshes..

Figure 20. Aerial and ground views of a dieback area (site 6) that showed little vegetative recovery in September 2001.

Figure 21. Example of a Spartina alterniflora marsh (site 17) that recovered from dieback

Figure 22. Aerial and ground views of a Spartina alterniflora marsh

(site 2) recovering from dieback

Figure 23. Sequence of shoot degradation in dieback marshes and role of snails

Figure 24. Primary rooting depth and Spartina alterniflora rooting depth in dieback and control marshes in August-0ctober 2000

Figure 25. Views of Avicennia germinans and Juncus roemerianus root systems.

Figure 26. Reddish-orange coloration observed in the shoots, roots/rhizomes, and soil at some sites during early stages of dieback (August 2000)......... 
Figure 27. Distant and close-up views of dry, cracked soil at a Spartina alterniflora dieback area........................................................................ 65 


\section{Tables}

Table 1. Summary of plant and soil variables measured on each sampling date.

Table 2. Summary of plant characteristics at a dieback site near Bay Junop in June 2000.

Table 3. Results of a repeated-measures ANOVA for plant (Spartina alterniflora) variables measured at dieback and control sites

Table 4. ANOVA results for physicochemical variables measured at Bay Junop in June 2000

Table 5. Results of a repeated-measures ANOVA for soil variables measured at Spartina alterniflora-dominated dieback sites.

Table 6. Summary of physicochemical conditions (averaged over site and time) measured in stands dominated by Spartina alterniflora.....

Table 7. Summary of physicochemical conditions (averaged over site and time) measured in stands dominated by Juncus roemerianus and Spartina patens.

Table 8. Water-extractable soil elemental concentrations $(\mathrm{mg} / \mathrm{kg})$ measured in August 2000 at dieback and reference marshes dominated by Spartina spp

Table 9. Ammonium acetate-extractable soil elemental concentrations $(\mathrm{mg} / \mathrm{kg})$ measured in August 2000 at dieback and reference marshes dominated by Spartina spp......

Table 10. Factor analysis of soil elemental concentrations measured at dieback and control sites in August 2000.

Table 11. Water-extractable soil elemental concentrations $(\mathrm{mg} / \mathrm{kg})$ 
measured in April 2001 at dieback and reference marshes dominated by Spartina spp...................................................................

Table 12. Ammonium acetate-extractable soil elemental concentrations $(\mathrm{mg} / \mathrm{kg})$ measured in April 2001 at dieback and reference marshes dominated by Spartina spp..................................................

Table 13. Acid-extractable soil elemental concentrations $(\mathrm{mg} / \mathrm{kg})$ measured in April 2001 at dieback and reference marshes dominated by Spartina spp................................................................

Table 14. Factor analysis of soil elemental concentrations measured at dieback and control sites in April 2000.

Table 15. Results of ANOVA for soil pyrite (August 2000) and acid extractable Al and Fe concentrations (April 2001)

Table 16. Elemental concentrations $(\mu \mathrm{g} / \mathrm{g})$ measured in Spartina alterniflora leaves in August 2000 at dieback and reference marshes

Table 17. Elemental concentrations $(\mu \mathrm{g} / \mathrm{g})$ measured in Spartina alterniflora leaves in April 2001 at dieback and reference marshes.

Table 18. Elemental concentrations $(\mu \mathrm{g} / \mathrm{g})$ measured in Spartina alterniflora (sites 2-21) and $S$. patens (site 1) leaves in September 2001 at dieback and reference marshes

Table 19. Elemental concentrations $(\mu \mathrm{g} / \mathrm{g})$ measured in Spartina patens (site 1) and Juncus roemerianus (site 16) leaves in August 2000 (A) and April 2001 (B) 50

Table 20. Factor analysis of plant elemental concentrations measured 
at dieback and control sites in August 2000, April 2001, and

September 2001.............................................................................. 52 


\title{
Salt Marsh Dieback in Coastal Louisiana: Survey of Plant and Soil Conditions at 23 Sites in Barataria and Terrebonne Basins, June 2000-September 2001
}

\author{
By Karen L. McKee', Irving A. Mendelssohn², and Michael D. Materne ${ }^{3}$
}

\section{Executive Summary}

Sudden and extensive dieback of the perennial marsh grass, Spartina alterniflora Loisel (smooth cordgrass), which dominates regularly flooded salt marshes along the Gulf of Mexico and Atlantic coastlines, occurred in the coastal zone of Louisiana. The objectives of our study were to assess soil and plant conditions in dieback areas of the Barataria-Terrebonne estuarine system as well as vegetative recovery during and after this dieback event. We examined dieback marshes from June 2000 until the end of the event when signs of vegetative recovery were evident (September 2001). Information was collected directly from multiple dieback sites along $100 \mathrm{~km}$ of shoreline from the Atchafalaya River to the Mississippi River. In addition to ground assessment of dieback conditions and vegetative recovery, we evaluated potential causes of dieback by using data collected from these surveys, historical records, and known tolerance limits of salt marsh vegetation to environmental stress factors.

Intensive examination of plant and soil characteristics at multiple dieback sites provided some important insights into the dieback process, vegetative recovery, and causation. Some areas of salt marsh were completely dead by June 2000 (Bay Junop), and plant shoots were substantially decomposed in most dieback sites by August 2000. This timeline of vegetative condition supports the hypothesis that the dieback event began in early spring of 2000. The pattern of dieback was distinctive and suggested a correlation with tidal flushing; i.e., the greatest mortality occurred in the marsh interior, whereas fringing vegetation along shorelines of bays and tidal creeks often retained some living shoots. In salt marshes, only $S$. alterniflora appeared to be affected; sympatric species such as Avicennia germinans (L.) Stearn (black mangrove), Batis maritima L. (saltwort), Distichlis spicata (L.) Greene (seashore saltgrass), and Juncus roemerianus Scheele (needlegrass rush) showed no visible signs of stress, even though they were growing in mixture or immediately adjacent to dead stands of $S$. alterniflora. Brackish marsh dieback of Spartina patens (Ait.) Muhl. (marshhay cordgrass) was observed at one site (Point Au Fer). This study confirmed that these spatial patterns of dieback and differential species susceptibility occurred repeatedly across the Barataria-Terrebonne estuarine system. The documentation of consistent patterns is important to concurrent research on causation and supports the hypothesis that the cause was a regional factor (e.g., drought) that interacted with local patterns of soil chemistry and/or hydrology.

${ }^{1}$ USGS-National Wetlands Research Center, 700 Cajundome Blvd, Lafayette, LA 70506 ${ }^{2}$ Wetland Biogeochemistry Institute, Louisiana State University Campus, Baton Rouge, LA 70803 ${ }^{3}$ USDA-Natural Resources Conservation Service, Louisiana State University Campus, Baton Rouge, LA 70803; Current address: Department of Agronomy, Louisiana State University, Baton Rouge, LA 70803 
Little or no expansion of dieback occurred subsequent to the initial event, and areas with moderate dieback ( $\sim 50$ percent mortality) had completely recovered by April 2001. These data demonstrate the ephemeral nature of the dieback agent, which apparently had no residual effects on plant recovery. Rapid recovery of moderately impacted marsh was due to survival of S. alterniflora rhizomes. Slow recovery of interior marshes that experienced greater than 90 percent shoot mortality was attributable to low survival of rhizomes and variable recolonization by seedlings and/or vegetative expansion from edges. However, regenerating plants in dieback areas were robust (culm heights $\sim 1.5 \mathrm{~m}$ ), and reproductive output was high, indicating that post-dieback conditions were actually promoting growth of S. alterniflora. Vigorous growth in dieback areas was likely due to a greater availability of nutrients and/or light. Stands of J. roemerianus, D. spicata, and A. germinans within or near some dieback sites remained largely unchanged or expanded into the dead $S$. alterniflora marsh during the observation interval. Although further monitoring is needed to confirm the extent of recovery, our observations indicate a high potential for natural recovery from the dieback event. However, some areas that showed no recovery by September 2001 (one full growing season after dieback) may convert to open water.

The cause of the dieback is currently unknown, primarily because the causative agent left no conclusive signature in plant or soil variables. Soil conditions were generally within normal ranges for salt marshes during the dieback event (June to October 2000) and during vegetative recovery (April to September 2001). However, our data either eliminate or are inconsistent with some proposed causes. We specifically examined three potential causes of marsh dieback in terms of consistency with the spatial pattern of dieback, the differential susceptibility of marsh species and their known stress tolerances, and the temporal sequence of dieback and recovery.

\section{Biotic Agents}

We found no evidence in support of a biotic agent as the primary cause of marsh dieback. Although potential fungal pathogens were isolated from S. alterniflora, these were species that typically infect previously stressed vegetation and are therefore unlikely to be the sole cause of dieback. Fungal or other pathogens also cannot explain the consistent spatial pattern of dieback. Fungal pathogens may have played a secondary role in plant mortality through interaction with an abiotic stress factor, but further experiments are required to test this possibility.

Outbreaks of insects or other herbivores were also ruled out as potential causes, based primarily on the spatial pattern and extent of dieback as well as the condition of dead and dying vegetation. Our observations specifically do not support the contention that dieback was caused by excessive grazing by Littoraria irrorata (marsh periwinkle). The data instead indicate that snails responded to the dieback and played an important role in rapid degradation of standing dead plants in some areas.

\section{Excessive Soil Waterlogging and Sulfide}

Although soil waterlogging and sulfide toxicity have been implicated in historical dieback of $S$. alterniflora, our data do not support this explanation with respect to acute marsh dieback. Historical records do not indicate that water levels were abnormally high 
in interior marshes during spring 2000 but instead show that this was a period of unusually low water levels. Elevated sulfide concentrations were found in dieback marshes, but they may have occurred because death of the vegetation stimulated sulfate reduction. In addition, we found no evidence of sulfide concentrations that exceeded the tolerance limits of S. alterniflora during the study period (June 2000 to September 2001) and generally found conditions that were typical of interior marshes. Also, this explanation does not account for the dieback of Spartina spp. and survival of other species that are known to be sensitive to sulfide (e.g., Avicennia germinans) (McKee, 1993). Finally, sulfide concentrations remained elevated or even increased over time in areas where revegetation occurred. However, waterlogging and elevated sulfide in interior marshes may have increased the susceptibility of Spartina spp. to another stress factor that precipitated the dieback event.

\section{Drought and Low Water Levels}

The dieback event was coincident with an extreme drought condition, low river discharge, and low sea level. Drought, combined with less tidal flooding, may have decreased water availability directly, increased salinity by concentrating salts in the pore water, and/or caused oxidation and acidification of soils.

\section{Direct Lack of Water}

We found evidence of dry, cracked soils at a few sites, indicating that these marshes can become desiccated under certain conditions. However, most sites were flooded at the time of our surveys. Our data thus cannot eliminate the possibility that a direct lack of water caused plant mortality. However, greenhouse experiments were unable to duplicate this hypothesized effect on $S$. alterniflora, even when water was withheld for $30 \mathrm{~d}$ (Mendelssohn and others, 2005).

\section{Hypersalinity}

We found no evidence in support of hypersalinity as a cause of marsh dieback. Soil salinities measured at dieback sites from June 2000 to September 2001 were within the ecological range of S. alterniflora and well below the lethal limit for this species. In addition, salinity did not have a significant effect on mortality of S. alterniflora in experiments designed to simulate dieback (see Mendelssohn and others, 2005). However, the most convincing evidence against this hypothesis is the fact that $J$. roemerianus, a species with lower salt tolerance growing within $S$. alterniflora dieback areas, not only survived the event, but also showed little or no signs of stress. The differential salt tolerance of these species has been confirmed in controlled laboratory experiments (see Mendelssohn and others, 2005).

\section{Soil Acidification and Metal Toxicity}

When saline sediments are aerated during drying, microbial oxidation of pyrite and sulfide generates sulfuric acid, which leads to soil acidification and ultimately to the release of potentially toxic metals such as aluminum and iron. Our data are consistent with this explanation. Dieback sites had higher concentrations of pyrite and acid- 
extractable aluminum and iron than did reference marshes that did not die. Plants from dieback marshes also contained significantly higher ratios of aluminum and iron, indicating increased uptake of potentially toxic metals, than did those growing along nearby shorelines and in reference marshes where plant mortality was low. The subsequent decline of tissue metal ratios in recovering vegetation further substantiates this explanation. In addition, laboratory trials demonstrated that soils from dieback marshes acidified upon oxidation, whereas those from reference sites did not. The fact that salt marsh sediments accumulate more trace and heavy metals because of mineral input from rivers compared to intermediate and freshwater marshes with more organic substrates and that they show greater decreases in $\mathrm{pH}$ upon oxidation is also consistent with the regional pattern of dieback primarily in saline marshes.

A better understanding of this acute dieback event and its consequences relative to historical dieback in Barataria-Terrebonne salt marshes is needed to aid in conservation and restoration efforts. Just as important are the implications of this event for global change models that focus mainly on sea-level rise as the dominant variable controlling vegetation patterns in coastal ecosystems. The sudden dieback of salt marshes in Louisiana suggests that periodic climatic extremes may cause rapid, widespread mortality of vulnerable species. The implications of this event for other coastal systems are unclear, partly because the precise causal mechanism for the acute dieback in the Mississippi River deltaic plain is not known. Also, preexisting stress conditions may play a role in acute dieback, but how and to what degree is not currently understood. The Mississippi delta is perhaps an extreme case since it has been undergoing high rates of apparent sea-level rise ( 8.5 to $9.5 \mathrm{~mm} / \mathrm{yr}$ ) and marsh deterioration. Nonetheless, the sudden dieback of $S$. alterniflora marshes in Louisiana suggests that large-scale changes in coastal vegetation may occur much more rapidly than current models predict and as a consequence of weather extremes acting in concert with sea-level fluctuations and preexisting soil conditions. Management plans usually do not take disturbance into account because of unfamiliarity or a belief that the disturbance cannot be managed. However, even if a disturbance cannot be controlled, the resilience and recovery of the system may be altered by management (Dale and others, 1998). Such considerations will become increasingly important as global climate changes and as human pressures in the coastal zone grow. 


\section{Abstract}

Sudden and extensive dieback of the perennial marsh grass, Spartina alterniflora Loisel (smooth cordgrass), which dominates regularly flooded salt marshes along the Gulf of Mexico and Atlantic coastlines, occurred in the coastal zone of Louisiana. The objectives of this study were to assess soil and plant conditions in dieback areas of the Barataria-Terrebonne estuarine system as well as vegetative recovery during and after this dieback event. Multiple dieback sites were examined along $100 \mathrm{~km}$ of shoreline from the Atchafalaya River to the Mississippi River during the period from June 2000 through September 2001. The species primarily affected was S. alterniflora; sympatric species such as Avicennia germinans (L.) Stearn (black mangrove) and Juncus roemerianus Scheele (needlegrass rush) showed no visible signs of stress. The pattern of marsh dieback was distinctive with greatest mortality in the marsh interior, suggesting a correlation with local patterns of soil chemistry and/or hydrology. Little or no expansion of dieback occurred subsequent to the initial event, and areas with 50 percent or less mortality in the fall of 2000 had completely recovered by April 2001. Recovery was slower in interior marshes with 90 percent or greater mortality initially. However, regenerating plants in dieback areas showing some recovery were robust, and reproductive output was high, indicating that the causative agent was no longer present and that post-dieback soil conditions were actually promoting plant growth. Stands of other species within or near some dieback sites remained largely unchanged or expanded (A. germinans) into the dead salt marsh.

The cause of the dieback is currently unknown. Biotic agents and excessive soil waterlogging/high sulfide were ruled out as primary causes of this acute event, although they could have contributed to overall plant stress and/or interacted with the primary agent to cause plant mortality. Our observations over the 15 month study specifically do not support the contention that dieback was caused by excessive grazing by Littoraria irrorata (marsh periwinkle). Instead, the data show that snails were responding to plant mortality and played an important role in rapid degradation of dead material in some areas. The dieback event was coincident with an extreme drought, low river discharge, and low sea level. These conditions could have caused plant mortality by directly decreasing water availability, increasing salinity, and/or causing oxidation and acidification of soils. The latter scenario was supported by findings of higher pyrite and acid-extractable aluminum and iron, higher acidification potential of dieback soils, and higher concentrations of aluminum and iron in dieback plant tissues (indicating uptake of potentially toxic metals) when compared to reference marshes showing no dieback. The implication of these findings is that periodic weather extremes may play a greater role in shaping coastal plant communities than has previously been recognized. Although such events may not be controlled directly, the resilience and recovery of the system may be altered by management. Such considerations will become increasingly important as global climate changes and human pressures in the coastal zone grow. 


\section{Introduction}

Sudden and extensive dieback of the perennial marsh grass, Spartina alterniflora Loisel. (smooth cordgrass), which dominates regularly flooded salt marshes along the Gulf of Mexico and Atlantic coastlines, occurred in the coastal zone of Louisiana. First observations of "browning" marsh were made in May 2000 by personnel of the Louisiana Department of Wildlife and Fisheries (G. Linscombe and R. Chabreck, public communication, www.brownmarsh.net, accessed 21 August 2003) and later confirmed by aerial surveys conducted by the U.S. Geological Survey National Wetlands Research Center (NWRC) (T. Michot, public communication, www.brownmarsh.net, accessed 21 August 2003). These aerial surveys indicated that extensive areas of salt marsh were moderately to severely damaged with only 35 percent of the total showing no signs of dieback. The dieback was initially most evident in the Fourleague Bay area but subsequently was reported throughout the Barataria and Terrebonne basins. The dieback appeared to occur over a short period of time. Preliminary ground surveys revealed that anywhere from 50 to 100 percent mortality of plant shoots had occurred as early as June 2000 in some areas of southeastern Louisiana. The pattern of dieback was distinctive in some areas and suggested a correlation with tidal flushing; i.e., the greatest mortality occurred in the marsh interior, whereas fringing vegetation along shorelines of bays and tidal creeks often retained some living shoots. In salt marshes, only $S$. alterniflora appeared to be affected; sympatric species such as Avicennia germinans (L.) Stearn (black mangrove) and Juncus roemerianus Scheele (needlegrass rush) showed no visible signs of stress, even though they were growing in mixture or immediately adjacent to dead stands of S. alterniflora. Brackish marsh dieback (Spartina patens (Ait.) Muhl. (marshhay cordgrass) was reported in Rockefeller State Wildlife Refuge and Game Preserve but was small in areal extent (Nyman and others, 2001) compared to that observed in salt marshes.

This recent dieback of salt marsh was unprecedented in the region's recorded history. Sudden marsh dieback has been reported elsewhere in the Gulf of Mexico and the Atlantic coast (Florida: Carlson and others, 2001; Georgia: Georgia Coastal Research Council, public communication accessed 24 April 2003, http://alpha.marsci.uga.edu/ coastalcouncil/marsh_dieback.htm; South Carolina: J.T. Morris, personal communication), but these occurrences do not approach the large-scale occurrence observed in Louisiana. The large extent and rapidity of this event also distinguish it from the long-term phenomenon previously described (Smith, 1970; Mendelssohn and others, 1983; Turner, 1990). Historically, coastal wetlands in the Mississippi River deltaic plain have been gradually converting to open water because of a combination of natural processes related to the Mississippi River deltaic cycle (Scruton, 1960) and human activities (Turner, 1990). Historical dieback of $S$. alterniflora is caused by excessive soil waterlogging, which limits aeration of plant roots and allows buildup of soil phytotoxins such as sulfide (Mendelssohn and others, 1981; Mendelssohn and McKee,1988; Koch and others, 1990; Wilsey and others, 1992; Webb and others, 1995). However, historical dieback occurs gradually and typically requires years for a marsh to completely die.

The objectives of our study were to assess soil and plant conditions in dieback areas as well as vegetative recovery during and after sudden dieback (June 2000September 2001). Information was collected directly from multiple dieback sites along 
$100 \mathrm{~km}$ of shoreline from the Atchafalaya River to the Mississippi River. In addition to ground assessment of dieback conditions and vegetative recovery, we evaluated potential causes of dieback by using data collected from surveys, historical records, and known tolerance limits of salt marsh vegetation to environmental stress factors. We tested three hypotheses that might explain the dieback event:

1. Dieback was caused by a biotic agent, such as fungal pathogens or excessive grazing or "eat-outs" by snails, nutria, or other herbivores.

2. Dieback was caused by unusually high water levels that either (a) submerged plants, particularly those at low elevations in interior marshes, and directly caused root hypoxia and plant death and/or (b) caused a soil buildup of sulfide or some other fermentative product toxic to plants.

3. Dieback was caused by low water levels in combination with extreme drought, which led to mortality of the vegetation because of a direct lack of water, hypersalinity, and/or soil acidification and release of toxic metals (e.g., Fe, Al, Mn).

\section{Study Sites and Experimental Design}

\section{Preliminary Survey at Bay Junop}

A preliminary ground survey of a dieback marsh was made in the Bay Junop area in June 2000 just after the phenomenon was reported in coastal Louisiana (fig. 1). Three transects were established perpendicular to the shoreline and traversed three marsh zones: healthy shoreline and dead interior zones dominated by $S$. alterniflora and a healthy stand of A. germinans. Live and dead stem densities of $S$. alterniflora and soil conditions (redox potential, bulk density, salinity, $\mathrm{pH}$, and sulfide; see detailed methods below) were determined at 1, 5, 10, 15, 30, 45, 60, and $75 \mathrm{~m}$ intervals from the shoreline. A reference marsh (showing no signs of dieback in June 2000) near Old Oyster Bayou was simultaneously examined.

\section{Intensive Survey across Terrebonne and Barataria Basins}

A more detailed survey of multiple dieback sites was undertaken in late summer of 2000. Dieback sites were selected based on maps derived from prior aerial surveys (G. Linscombe, personal communication) and were accessed by helicopter on August 30-31, 2000; October 4-5, 2000; April 26-29, 2001, and September 17-18, 2001. Eighteen dieback sites (fig. 1) of varying size were identified along $100 \mathrm{~km}$ of shoreline in the Mississippi River deltaic plain based on the occurrence of a distinct spatial pattern of mortality: healthy shoreline (less than 10 percent mortality), transition (50 percent mortality), and dead interior (greater than 90 percent mortality) (fig. 2). Nine sites were established in Terrebonne basin during August 2000 and nine sites in Barataria basin during October 2000 with funding from the Louisiana Sea Grant program. 


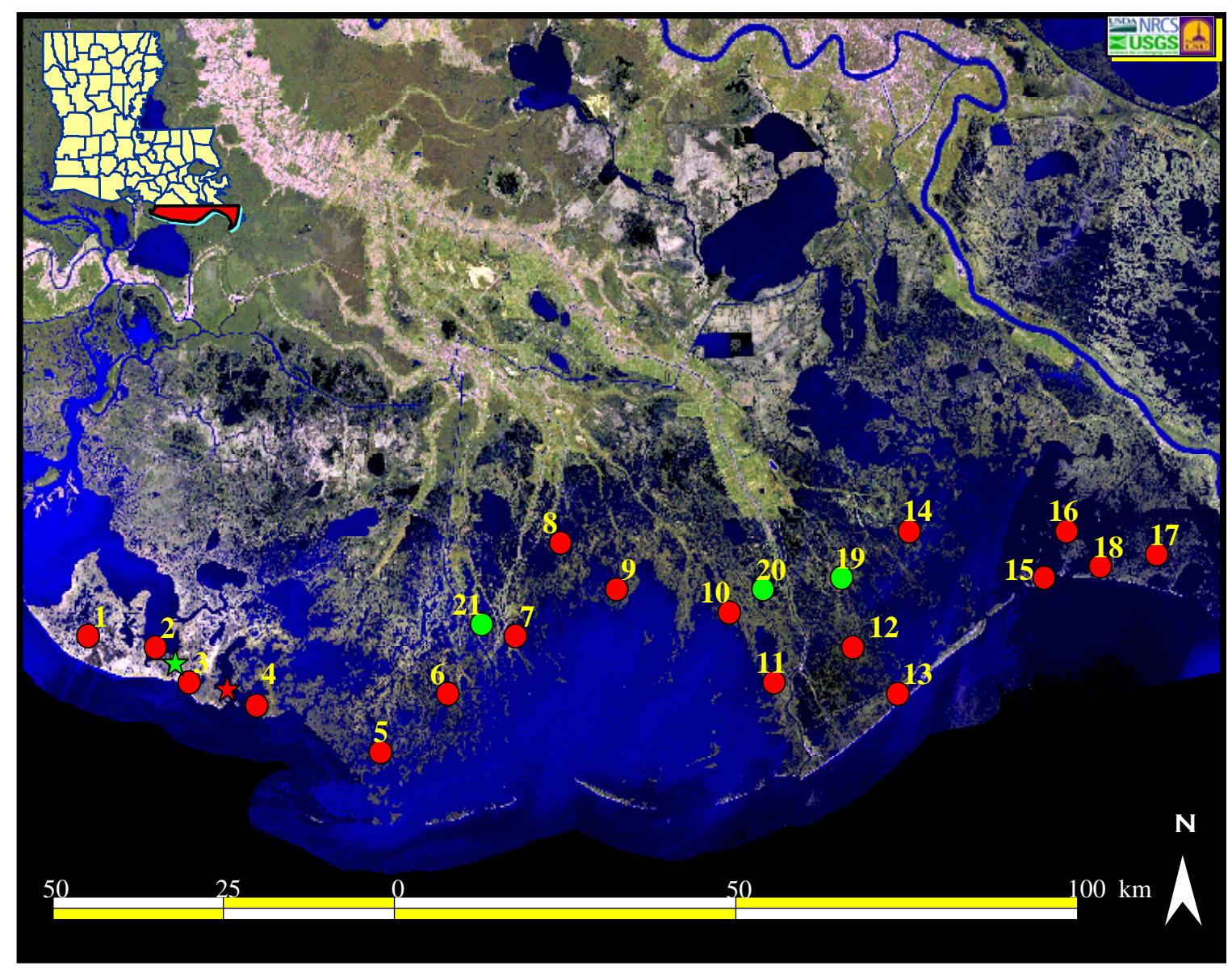

Figure 1. Location of 23 study sites in the Mississippi River deltaic plain. Preliminary dieback (Bay Junop) and control (Old Oyster Bayou) sites surveyed in June 2000 are indicated by red and green stars, respectively. Intensive survey sites established in August and October 2000 are indicated by circles. Intensive sites 1-18 (red) were in dieback areas, and sites 19-21 (green) were in control areas (no visible signs of dieback). 


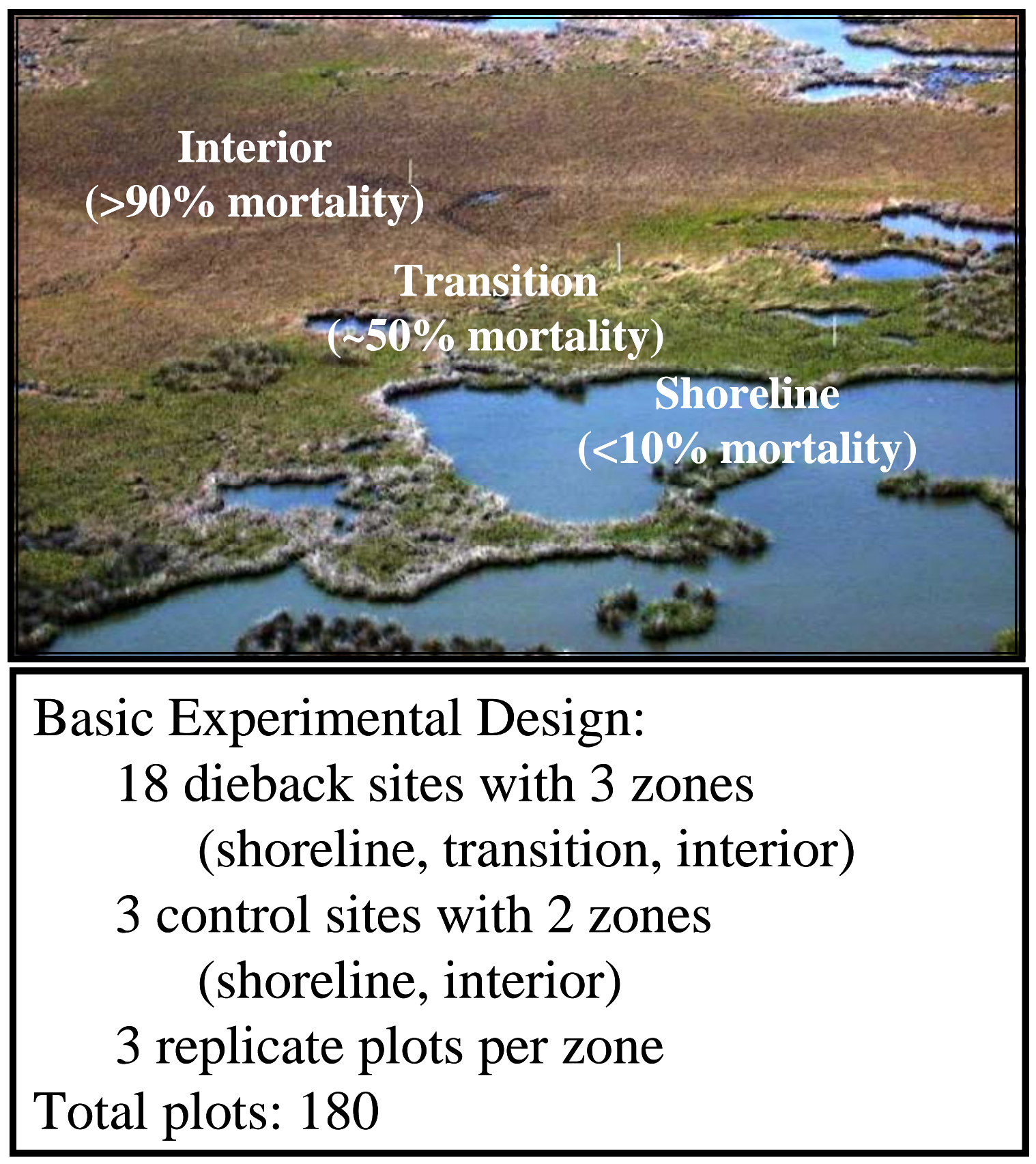

Figure 2. Experimental design used in the intensive survey of dieback and control marshes. Photograph illustrates the spatial arrangement of zones sampled at dieback marshes. In addition to the 180 plots in the basic design, an additional 9 regenerating plots (sites 4-6), 3 Juncus roemerianus plots (site 16), and 6 dieback shoreline plots (sites 15-16) were sampled for a total of 194 plots overall. 
A regenerating zone with new shoot growth emerging within an older dieback area, a dead shoreline zone, and patches of J. roemerianus were additionally selected for sampling at a few of the sites. Three control sites were also established in areas showing no dieback either along the shoreline or in the marsh interior. Initially, only interior plots were sampled at control marshes (August-October 2000), but both shoreline and interior plots were sampled on subsequent trips (April and September 2001). At all 21 sites, a permanent marker (PVC pipe) was installed in each of the three main zones (shoreline, transition, interior) to mark the sampling area. In each sampling area, three replicate plots were randomly selected by first marking 10 stations in the vicinity of the PVC pipe with numbered flags. Three of the flagged stations were then randomly selected on each sampling date by using a random numbers table.

\section{Methods}

Table 1 summarizes the plant and soil variables measured on each sampling date. Vegetative cover by species and condition (percent live/dead and status of standing dead stems) and leaf tissue cation and metal concentrations were measured on every sampling trip (intensive survey).

\section{Vegetative Condition}

Percent cover by condition and species was visually estimated inside a $0.25 \mathrm{~m}^{2}$ quadrat. Plants were identified to species, and condition of shoots was categorized as live, standing dead with leaves, standing dead without leaves, stubble (less than $5 \mathrm{~cm}$ of stem remaining), or bare (no vegetative cover). A $0.5-\mathrm{m}$ deep core was extracted with a Russian peat corer, and primary and maximum rooting depths were measured. Rhizome viability was assessed in August-October 2000 based on staining with triphenyltetrazolium chloride ( 1 percent $\mathrm{w} / \mathrm{v})$ solution. Five rhizomes per plot were extracted from root cores, washed free of sediment, cut into $1 \mathrm{~cm}$ sections, and placed into staining solution in the field and kept on ice and in the dark until analysis (within $24 \mathrm{~h}$ ). Rhizomes were sectioned longitudinally in the laboratory and examined under magnification to affirm staining of meristems. Additional samples were stained with indigocarmine $(0.05$ percent $\mathrm{w} / \mathrm{v})$ to confirm viability when the tetrazolium procedure was equivocal.

\section{Physicochemical Conditions}

Shallow soil cores were collected from each plot with a piston corer $\left(54.3 \mathrm{~cm}^{3}, 12\right.$ $\mathrm{cm}$ long $\mathrm{x} 1.2 \mathrm{~cm}$ radius) and stored in water-tight plastic bags until analysis. The soil was weighed, dried at $80^{\circ} \mathrm{C}$ to constant mass, and reweighed to determine bulk density (mass of dry soil per volume) and relative saturation (\%). The dried soil was ground with a mortar and pestle, and a subsample was ashed at $550^{\circ} \mathrm{C}$ for $6 \mathrm{~h}$ to determine mineral mass after organic loss on ignition.

Replicate redox potential $\left(E_{\mathrm{h}}\right)$ measurements were made in situ at two $(1,15 \mathrm{~cm}$; Bay Junop) or three (1, 15, and $30 \mathrm{~cm}$; Intensive Survey) soil depths in each plot to 
characterize reducing conditions in the soils (McKee and others, 1988). Bright platinum electrodes were inserted to the desired depth and allowed to equilibrate for a minimum of $30 \mathrm{~min}$ before measurement.

Table 1. Summary of variables measured by sampling date.

\begin{tabular}{lcccc}
\hline & Jun 2000 & Aug-Oct 2000 & Apr 2001 & Sep 2001 \\
\hline $\begin{array}{l}\text { Vegetative Condition } \\
\text { Percent Mortality }\end{array}$ & & $\mathrm{X}$ & $\mathrm{X}$ & $\mathrm{X}$ \\
Stem Density & $\mathrm{X}$ & $\mathrm{X}$ & & \\
Rhizome Viability & & $\mathrm{X}$ & $\mathrm{X}$ & \\
Rooting Depth & & $\mathrm{X}$ & $\mathrm{X}$ & $\mathrm{X}$ \\
Leaf Elements & & & & \\
& & $\mathrm{X}$ & $\mathrm{X}$ & $\mathrm{X}$ \\
Soil Condition & $\mathrm{X}$ & $\mathrm{X}$ & $\mathrm{X}$ & $\mathrm{X}$ \\
Salinity & $\mathrm{X}$ & $\mathrm{X}$ & $\mathrm{X}$ & $\mathrm{X}$ \\
pH & $\mathrm{X}$ & $\mathrm{X}$ & $\mathrm{X}$ & \\
Redox Potential & $\mathrm{X}$ & $\mathrm{X}$ & \\
Sulfide & $\mathrm{X}$ & $\mathrm{X}$ & \\
Percent Organic Matter & & $\mathrm{X}$ & $\mathrm{X}$ & \\
Water Content & $\mathrm{X}$ & $\mathrm{X}$ & $\mathrm{X}$ & \\
Bulk Density & & & & \\
Elemental Analysis & & $\mathrm{X}$ & & \\
Acidification Potential & & $\mathrm{X}$ & & \\
Fungal Pathogens & & & & \\
Shoot & & & & \\
Root/Rhizome & & & & \\
\hline
\end{tabular}

Voltage $(\mathrm{mV})$ between the platinum electrode and a calomel reference electrode was measured with a hand-held $\mathrm{pH} / \mathrm{mV}$ meter (Cole-Parmer, model 5938-00, Vernon Hills, Ill.) and corrected for the calomel potential by adding $244 \mathrm{mV}$ to the reading. Pore water samples were collected and processed according to McKee and others (1988). A sipper apparatus consisting of a rigid plastic tube connected to a $60 \mathrm{ml}$ syringe was used to extract interstitial water from the soil. The first $5 \mathrm{ml}$ of each extraction was discarded to remove debris, sediment, and gas. An aliquot of water for sulfide determination was added to an equal volume of antioxidant buffer (electrode operating instructions) upon collection, and all samples were analyzed with a sulfide electrode (Lazar Model IS-146 sulfide electrode, Lazar Research Laboratories, Los Angeles, Cal.). The remaining water was stored in glass vials for analysis of salinity (refractometer, Vista Model A366 ATC) and $\mathrm{pH}$ (pH/mV meter, model 5938-00, Cole-Parmer, Vernon Hills, Ill.). 


\section{Leaf and Soil Elemental Concentrations}

Leaf and soil samples for nutrient and metal analysis were kept cold until extraction. Leaf samples were rinsed thoroughly with deionized water, dried at $70^{\circ} \mathrm{C}$, ground in a Wiley Mill to pass a \#40 mesh sieve, and digested in concentrated nitric acid (Lachat BD-46 block digester, Lachat Instruments, Milwaukee, Wisc.). Soil samples were extracted sequentially with deionized water, ammonium acetate, and acid $(1 \mathrm{M} \mathrm{HCl}$ at $\mathrm{pH}$ 3.5). Extracts of soil and digested leaf samples were analyzed for total concentrations of $\mathrm{Ca}, \mathrm{Mg}, \mathrm{Na}, \mathrm{K}, \mathrm{Mn}, \mathrm{Fe}, \mathrm{Cu}, \mathrm{Zn}, \mathrm{Al}, \mathrm{S}$, and $\mathrm{P}$ with an inductively coupled plasma emission spectrometer (Soil Testing and Plant Analysis laboratory, Department of Agronomy, Louisiana State University).

\section{Soil Acidification Potential}

Acidification potential of soils was evaluated by using a subset of dieback ( 6 sites) and control (3 sites) soil samples from the intensive field survey. Soil ( $\sim 10 \mathrm{~g}$ wet wt) was added to flasks containing $250 \mathrm{ml}$ of artificial seawater. The flasks were covered to exclude light, fitted with stoppers, and purged with either $\mathrm{N}_{2}$ gas or air at a rate of 5 $\mathrm{ml} / \mathrm{min}$. The flasks were maintained at room temperature $\left(21-22{ }^{\circ} \mathrm{C}\right)$, and $\mathrm{pH}$ of the solution was measured at intervals of $0,6,13$, and $23 \mathrm{~d}$.

\section{Statistical Analyses}

Since sites, zones, and sampling dates were preselected, a fixed effects model was used to analyze the data (SAS Institute, 2003). However, because sampling frequency and zone by site combinations were not the same for all variables measured, the specific model differed among plant and soil datasets. For example, dieback sites had three zones (healthy shoreline, transition, and dieback interior), and control sites had only two zones (shoreline and interior). Data from the preliminary survey at Bay Junop (single site and sampling date) were analyzed as a one-way ANOVA with zone as the grouping factor. Variables measured once at all 21 sites, but in different combinations of zones within site (e.g., rhizome viability), were analyzed with a one-way ANOVA with site and zone (nested within site) as the grouping factors. Variables measured on every sampling date, but in different zones within sites (e.g., vegetative condition and tissue elemental concentrations), were analyzed with a repeated measures ANOVA with site, zone (nested within site), and time as grouping factors. For physicochemical variables, data from three zones (shoreline, transition, and interior) at all dieback sites dominated by S. alterniflora (sites 2-18), and three sampling dates were analyzed with a repeated measures ANOVA with site, zone, and time as grouping factors. Soil acidification (August 2000) was analyzed witht a two-way, repeated measures ANOVA with soil source (dieback or control), treatment (reduced or oxidized), and incubation time as grouping factors.

Data were $\log (\ln [\mathrm{x}+1])$ or arcsin transformed prior to analysis where necessary to reduce heterogeneity of variance and to reduce deviations from normality. Post-test comparisons among sites and zones were described with one degree of freedom contrasts for single comparisons of interest between two levels. A priori contrasts were constructed to make comparisons among zones at dieback marshes (i.e., healthy shoreline vs. transition or dieback interior zones) or between dieback interior and control interior 
marsh zones when a significant main effect of zone was found. Dieback (sites 1-18) marshes were contrasted with control (sites 19-21) marshes when a significant site effect was found. A significant interaction of time with either zone or site was interpreted as a difference in temporal patterns across levels of the grouping factor. However, because measurements made in the same plots on different dates are not independent samples, post-test comparisons of zone by time or site by time combination levels could not be conducted.

A factor analysis was performed on elemental concentrations in soil and plant tissue to reduce the number of variables and problems associated with multicollinearity. The factor extraction method was Principal Components Analysis (SAS Institute, 2003). A varimax rotation of factor scores was performed by using the JMP "factor rotation" procedure. The number of factors selected for rotation was based on the number of eigenvalues greater than unity for the correlation matrix of the test scores extracted from the data. Individual factor scores were then subjected to ANOVA to test for main effects of site and zone (nested within site). Data from each sampling date were analyzed separately because each dataset resulted in a different correlation matrix and factor loadings. If rotated factors extracted from the correlation matrix of elemental concentrations were interpretable and there was also a significant effect of site and/or zone on rotated factors, then individual elements with high loadings on that factor were examined further. Because the elements $\mathrm{Na}, \mathrm{Al}, \mathrm{Fe}$, and $\mathrm{Mn}$ were hypothesized to be causative agents in dieback (i.e., directly toxic to plants), these elemental concentrations (in soil and plant tissues) were particularly targeted for individual scrutiny. Tissue concentrations of these elements were tested as ratios of $\mathrm{K}^{+}(\mathrm{Na}: \mathrm{K}, \mathrm{Fe}: \mathrm{K}, \mathrm{Al}: \mathrm{K}$, and $\mathrm{Mn}: \mathrm{K})$.

\section{Results and Discussion}

\section{Scale and Pattern of Dieback}

Aerial surveys conducted by other investigators(http://www.brownmarsh.net, accessed 21 August, 2003) and us indicated that over $100 \mathrm{~km}$ of coastline and more than 100,000 ha of salt marsh were affected to some degree, with 43,000 ha severely damaged. We examined dieback marsh from the beginning of the phenomenon (June 2000) until the end of the event when signs of vegetative recovery were evident (September 2001). Our aerial observations covered $100 \mathrm{~km}$ of shoreline, and ground observations were conducted at a total of 23 sites established in Barataria and Terrebonne basins.

Preliminary examination of a dieback site near Bay Junop in June 2000 found standing dead but largely intact shoots of $S$. alterniflora adjacent to a healthy stand of $A$. germinans (black mangrove) (fig. 3, table 2$)$. A narrow fringe zone ( $<1 \mathrm{~m}$ in width) contained about 50 percent live shoots but transitioned abruptly into dead marsh. The height and density of dead stems in the dead marsh at Bay Junop were not different from those in the shoreline zone with live shoots, a fact suggesting that shoots had died suddenly and after attaining their full stature. Dead shoots exhibited no signs of damage other than desiccation; i.e., leaves and stems were mostly intact with no fraying, necrotic lesions, or visible evidence of herbivory, pathogens, or insect infestations. 


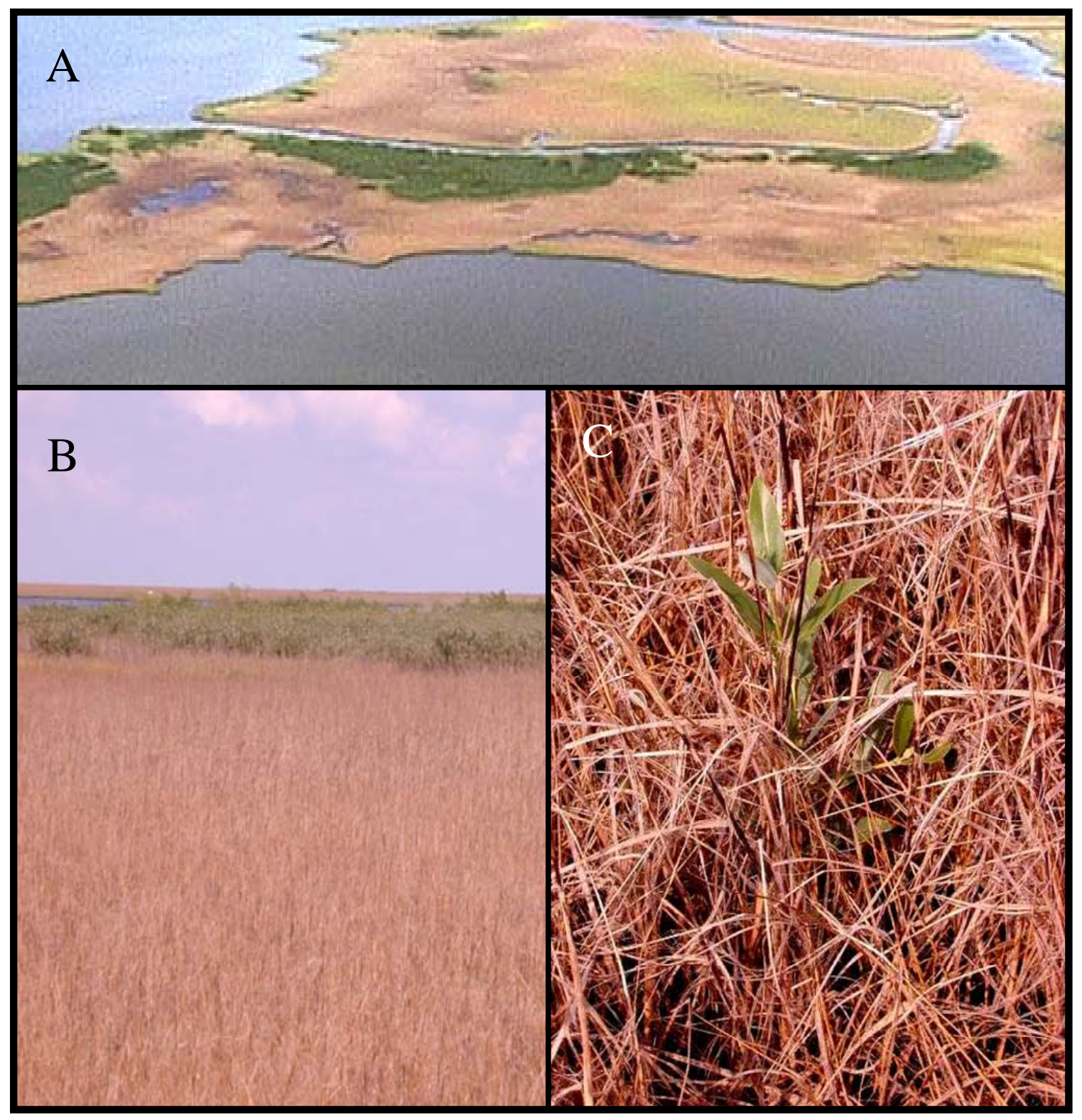

Figure 3. Views of preliminary survey site at Bay Junop in June 2000. (A) Aerial view of dieback marsh (brown) and Avicennia germinans (black mangrove) (dark green) (photo by Tommy Michot). (B) Ground views of dead Spartina alterniflora (smooth cordgrass) (foreground) and healthy A. germinans (background). (C) Healthy seedling of A. germinans growing within dead marsh. 
Table 2. Summary of Spartina alterniflora characteristics at a dieback site near Bay Junop in June 2000.

\begin{tabular}{|c|c|c|c|c|}
\hline & \multicolumn{2}{|c|}{$\underline{\text { Stem Density }\left(\mathrm{m}^{-2}\right)}$} & \multicolumn{2}{|c|}{$\underline{\text { Stem Height }(\mathrm{cm})}$} \\
\hline & Live & Dead & Live & Dead \\
\hline Shoreline & $290 \pm 130$ & $305 \pm 75$ & $39.1 \pm 4.1$ & $37.3 \pm 2.9$ \\
\hline Transition & $305 \pm 25$ & $510 \pm 131$ & $41.0 \pm 1.0$ & $34.6 \pm 2.3$ \\
\hline Interior & $0 \pm 0$ & $500 \pm 30$ & - & $44.4 \pm 0.6$ \\
\hline
\end{tabular}


A more extensive examination of 18 dieback areas in Terrebonne and Barataria Basins demonstrated that the pattern of marsh dieback was distinctive both on regional and local scales. Although dieback areas occurred in the Barataria basin, they were not as frequent or as large as in the Terrebonne basin, farthest from the Mississippi River. A consistent local pattern suggested a correlation with tidal flushing; i.e., the greatest mortality occurred in the marsh interior where tidal flushing of soil is minimal, while fringing vegetation along shorelines of bays and tidal creeks often had less than 75 percent live shoots (figs. 4-9). However, some fringing marshes along interior bays and tidal creeks did experience dieback in some areas (fig. 5B). The contrast between the 50 to 100 percent mortality of plant shoots in transition and interior zones and visually healthy stands along most shorelines (figs. 4-9, table 3) was similar to that observed earlier at Bay Junop (table 2) and indicated the widespread nature of this spatial pattern.

Shoot condition in dieback plots indicated a more advanced state of decay by late summer 2000, with many shoots without leaves or reduced to stubble (fig. 9, table 3). Examination of rhizomes, the main perennating organs, indicated that few belowground structures were viable in areas with high aboveground mortality (fig. 10). The marsh type primarily affected was salt marsh, and only two species appeared to be involved in the dieback: S. alterniflora and S. patens to a lesser extent (fig. 4). Sympatic species such as A. germinans (fig. 11), Batis maritima L. (saltwort) (fig. 5), Distichlis spicata (L.) Greene (seashore saltgrass), and J. roemerianus (fig. 12) survived the event and exhibited little or no visible signs of stress. 


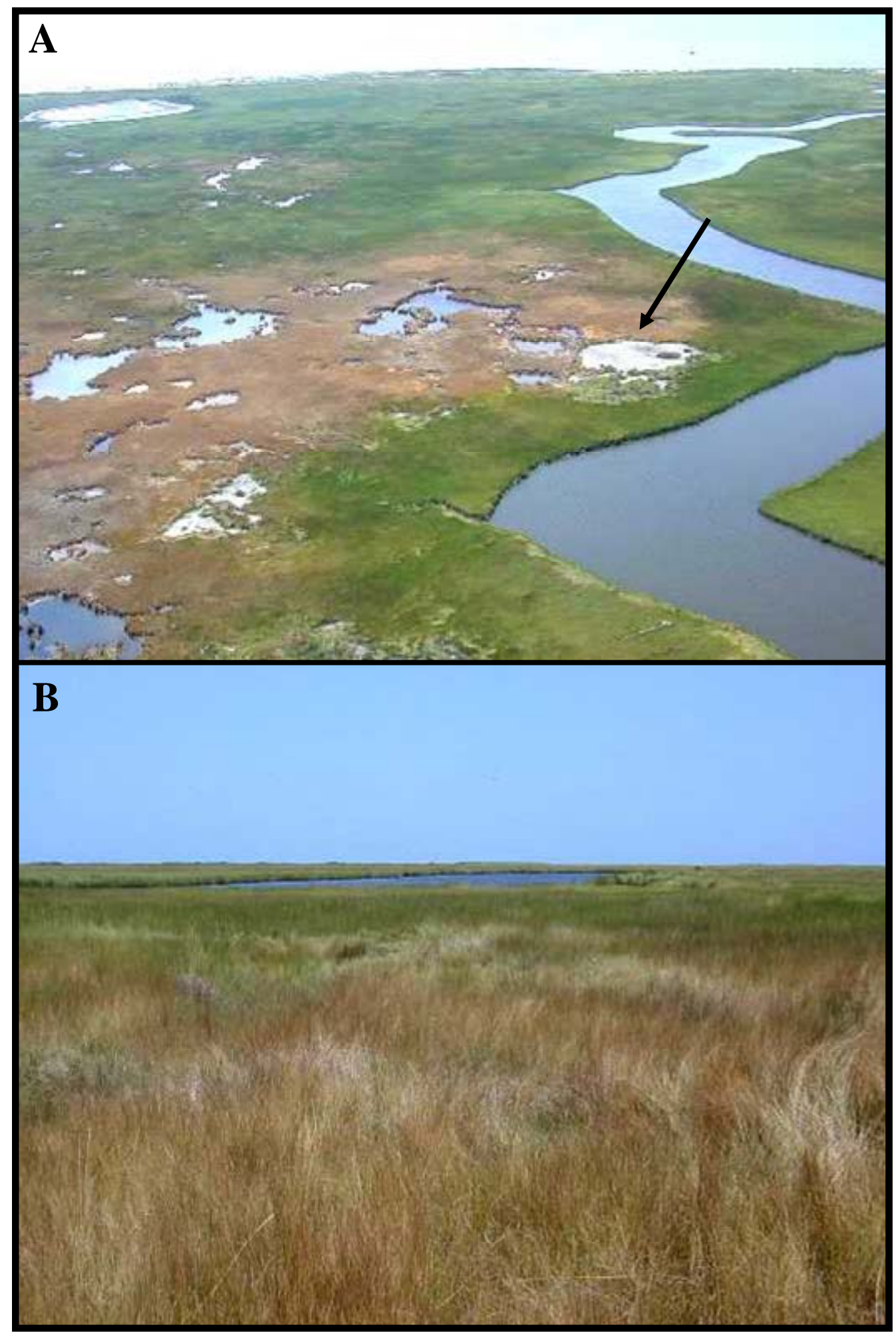

Figure 4. Aerial (A) and ground (B) views of a dieback Spartina patens (marshhay cordgrass) marsh (site 1) in August 2000. Note the spatial pattern of dieback in the marsh interior and healthy, green shoots along the shoreline. The arrow indicates a salt pan with crusts of salt on the dry soil surface. 


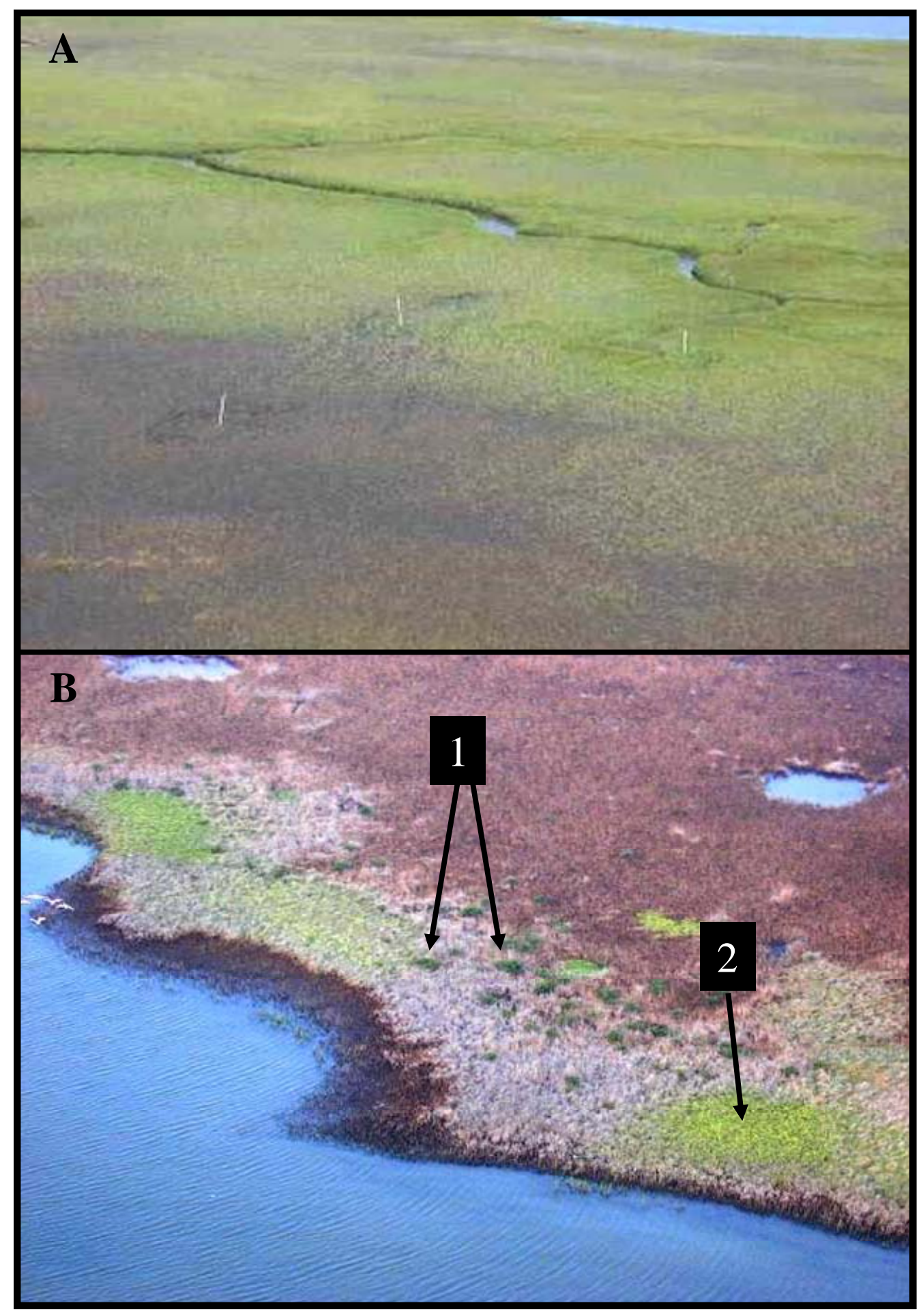

Figure 5. Spatial patterns of marsh dieback. Panel A illustrates an interior dead marsh with healthy vegetation along a tidal creek. Panel B shows Spartina alterniflora (smooth cordgrass) dieback along a shoreline as well as in the marsh interior. Arrows indicate (1) healthy Avicennia germinans (black mangrove) (dark green vegetation) and (2) Batis maritima (saltwort) (light green vegetation) growing in the midst of dead $S$. alterniflora. 


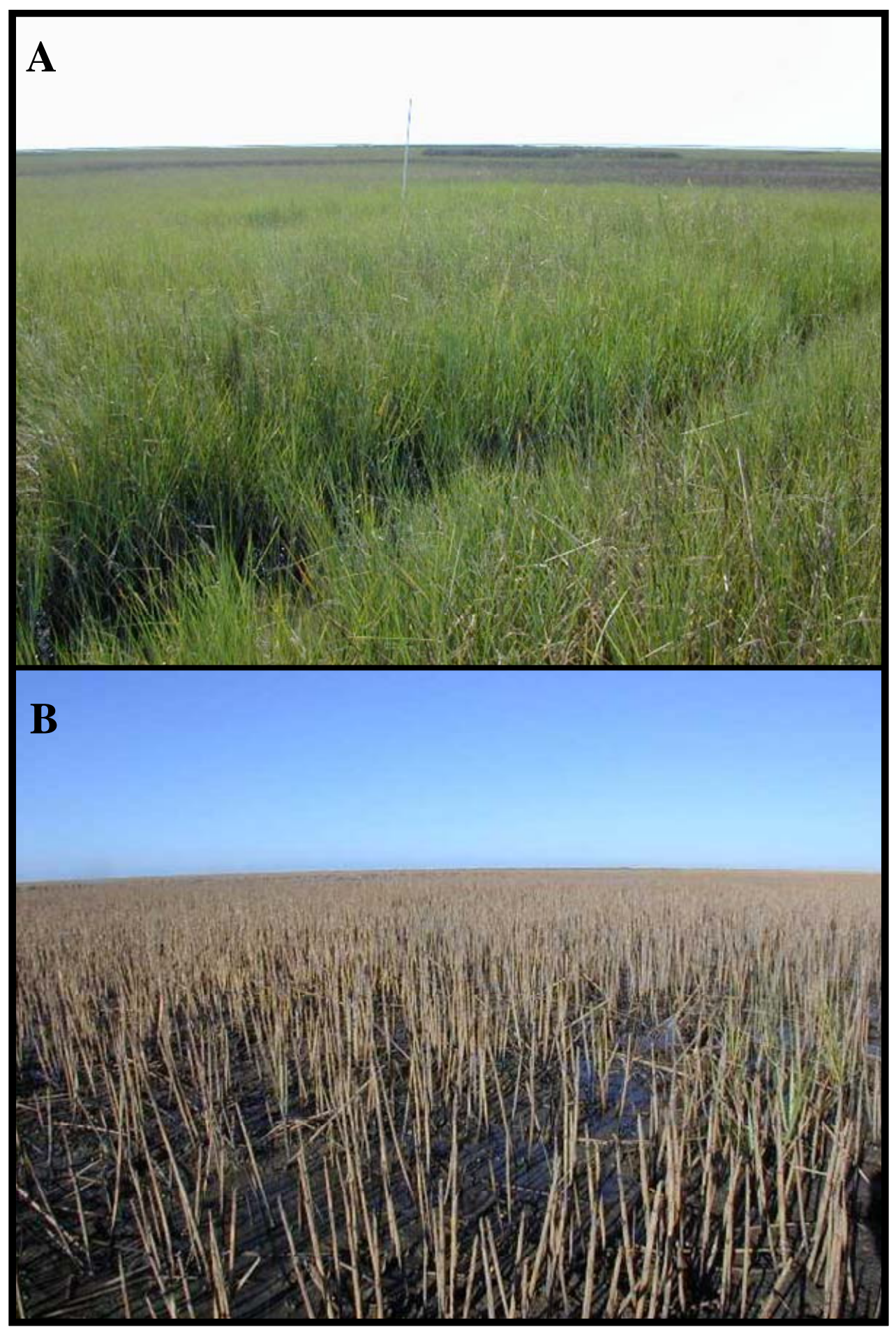

Figure 6. Ground views of (A) healthy shoreline and (B) dieback interior stands of Spartina alterniflora (smooth cordgrass) in August 2000. 

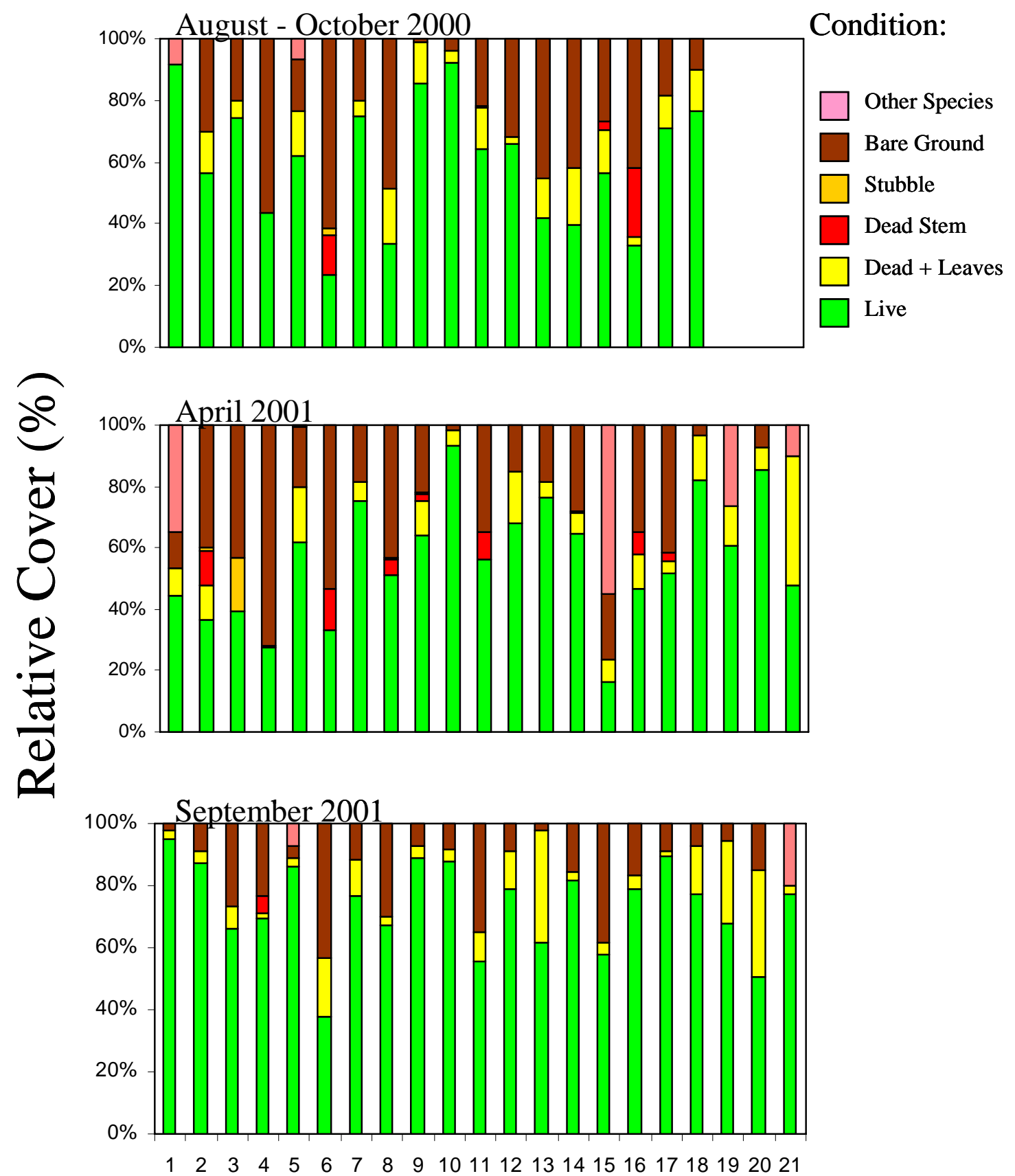

Site

Figure 7. Relative cover (percent of total) by condition measured in the shoreline zone of marshes dominated by Spartina patens (marshhay cordgrass) (site 1) or S. alterniflora (smooth cordgrass) (sites 2-21) on 3 dates. Values are the mean \pm 1 SE ( $n=3$ plots at dieback sites 1-18 and at control sites 19-21). 

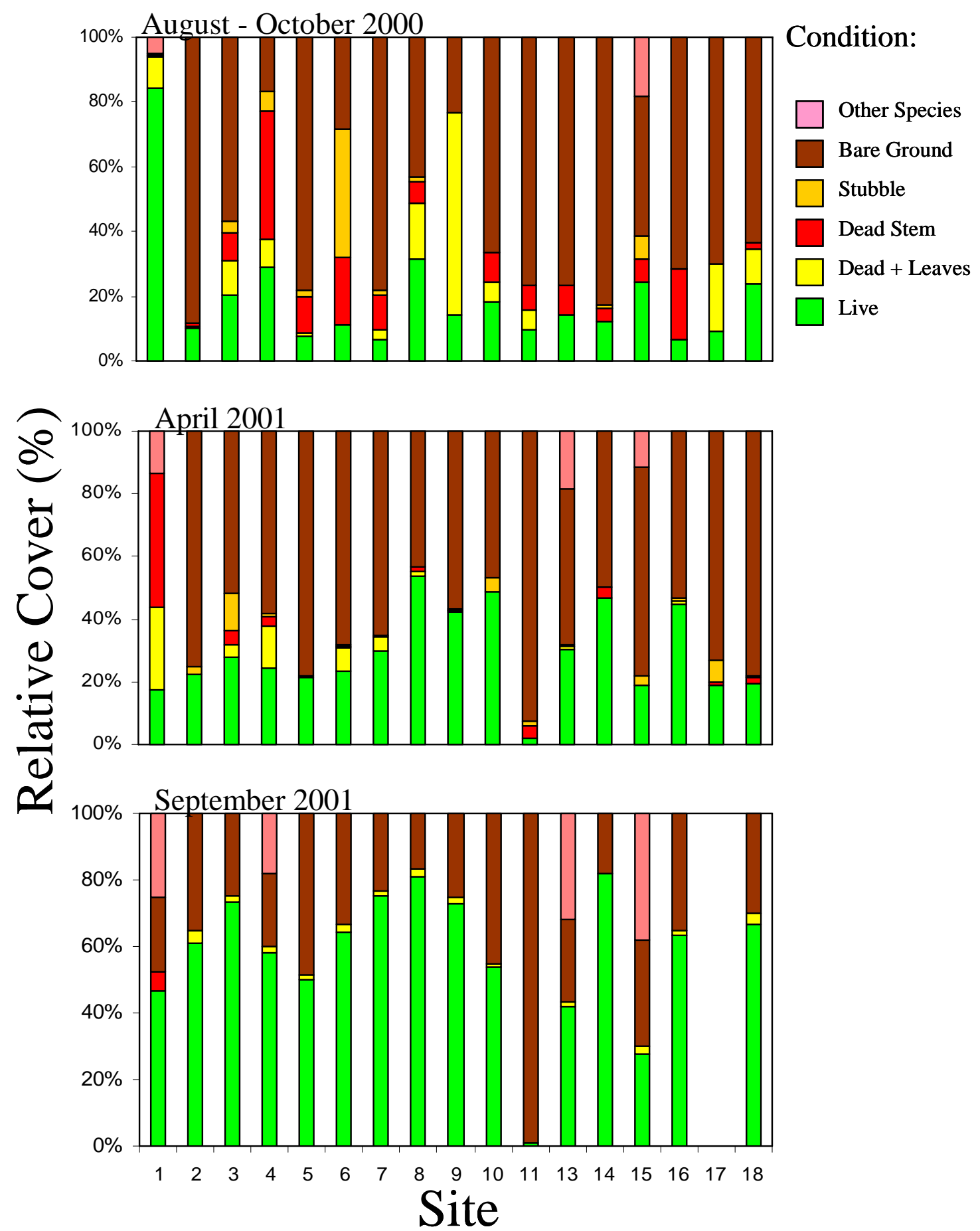

Figure 8. Relative cover (percent of total) by condition measured in the transition zone of marshes dominated by Spartina patens (marshhay cordgrass) (site 1) or S. alterniflora (smooth cordgrass) (sites 2-21) on 3 dates. Values are the mean \pm 1 SE ( $n=3$ plots at dieback sites 1-18). 

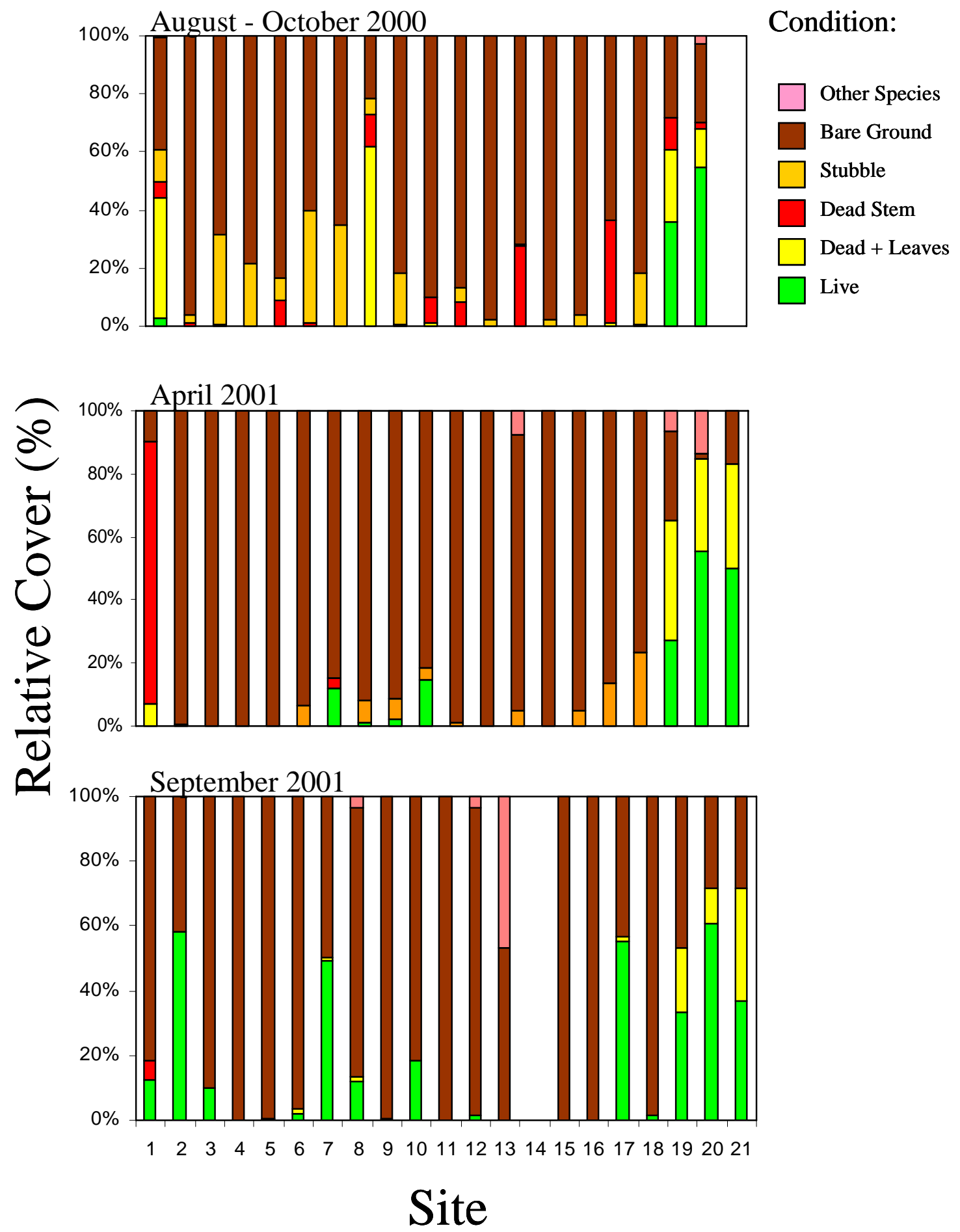

Figure 9. Relative cover (percent of total) by condition measured in the interior zone of marshes dominated by Spartina patens (marshhay cordgrass) (site 1) or S. alterniflora (smooth cordgrass) (sites 2-21) on 3 dates. Values are the mean \pm 1 SE ( $n=3$ plots at dieback sites 1-18). 

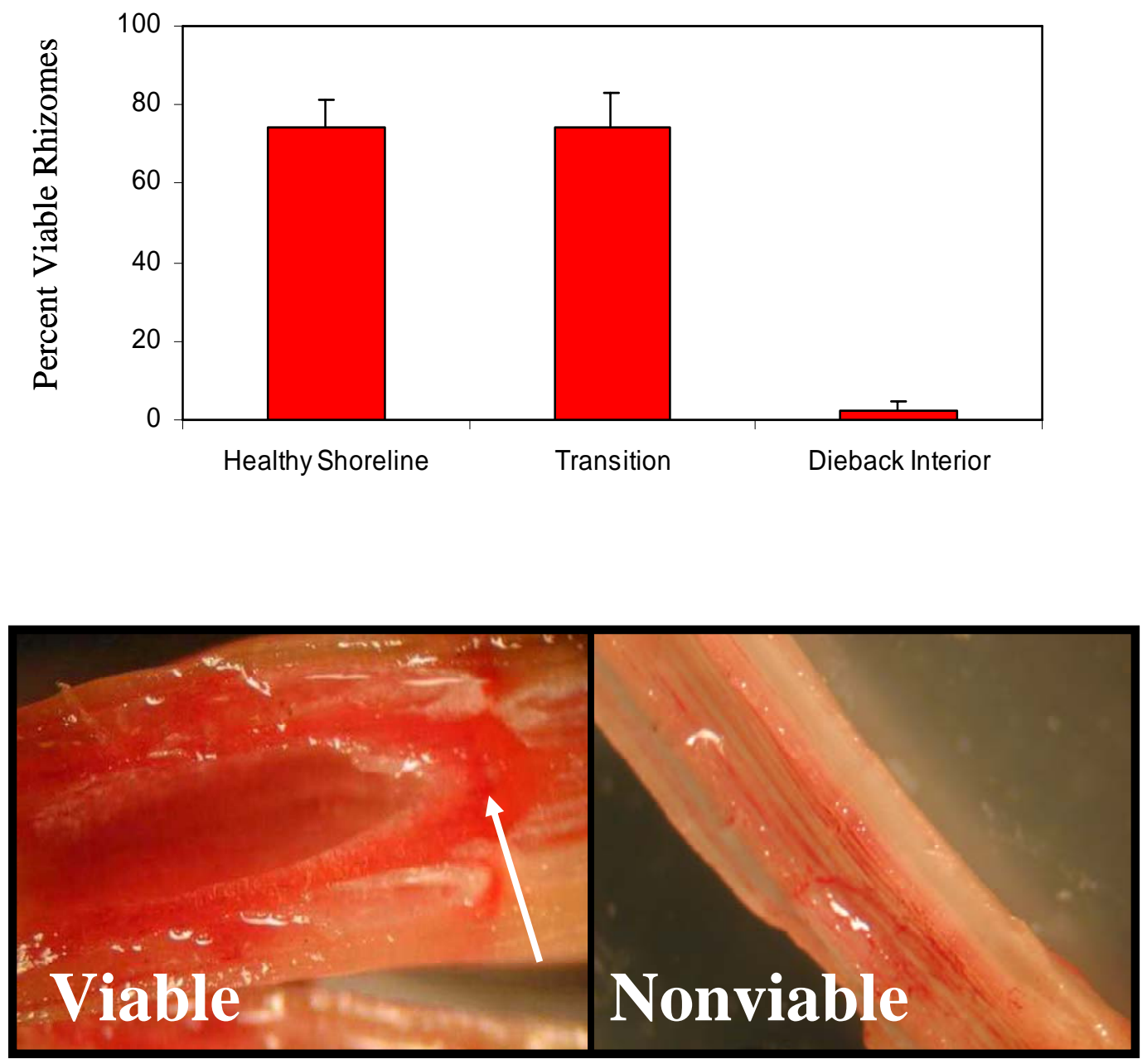

Figure 10. Viability of Spartina alterniflora (smooth cordgrass) rhizomes in AugustOctober 2000. Rhizomes were treated with triphenyltetrazolium chloride, which stains live cells a dark pink color. Meristematic tissue (arrow in left panel) was examined under magnification to affirm staining of rapidly growing root cells. Slight staining of root surface (right panel) was due to presence of microflora. 
Table 3. Results of repeated-measures ANOVA for plant variables of Spartina alterniflora (smooth cordgrass) measured at dieback and control sites where site, zone (nested within site), and time were grouping factors. Where a significant zone or zone*time effect was found, 1 degree of freedom contrasts were conducted for healthy shoreline (HS) versus dieback interior (DI) and transition (T) and for DI versus control interior (CI). Dieback (D) sites (1-18) were contrasted with control sites (19-21) where a significant site effect was found. Values are the F-ratio, and significance is indicated by $*(\mathrm{p} \leq 0.05), * *(\mathrm{p} \leq 0.01), * * *(\mathrm{p} \leq 0.001), * * * *(\mathrm{p} \leq$ 0.0001 ), or ns (not significant).

Source of Variation:

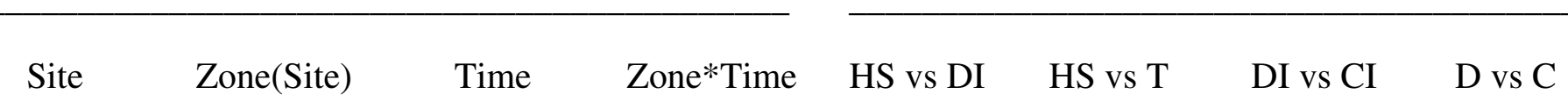

\begin{tabular}{|c|c|c|c|c|c|c|c|c|}
\hline \multicolumn{9}{|c|}{ Relative Cover by Shoot Condition: } \\
\hline \%Live & $21.03 * * * *$ & $67.23 * * * *$ & $8.10 * * * *$ & $5.65 * * * *$ & $5.66 * *$ & $67.25 * * * *$ & $1.45 \mathrm{~ns}$ & $10.29 * * * *$ \\
\hline$\%$ Stubble & $24.50 * * * *$ & $20.72 * * * *$ & $136.8 * * * *$ & $15.46 * * * *$ & $171.1 * * * *$ & $16.21 *$ & $41.98 * * * *$ & $7.84 * * *$ \\
\hline$\%$ Dead stem & $11.76 * * * *$ & $6.72 * * * *$ & $85.44 * * * *$ & $6.27 * * * *$ & $21.22 * * * *$ & $34.55 * * * *$ & $0.12 \mathrm{~ns}$ & $0.90 \mathrm{~ns}$ \\
\hline$\%$ Dead with leaves & $15.48 * * *$ & $10.46 * * * *$ & $35.06 * * * *$ & $7.68 * * * *$ & $3.12 *$ & $11.87 * * * *$ & $16.55 * * * *$ & $17.91 * * * *$ \\
\hline$\%$ Bare ground & $14.46 * * * *$ & $57.43 * * * *$ & $34.33 * * * *$ & $4.51 * * * *$ & $21.35 * * * *$ & $12.78 * * * *$ & $10.69 * * * *$ & $15.55 * * * *$ \\
\hline$\%$ Other species & $8.82 * * * *$ & $3.41 * * * *$ & $8.70 * * *$ & $2.97 *$ & $2.80 \mathrm{~ns}$ & $4.04 *$ & $3.30 *$ & $2.72 \mathrm{~ns}$ \\
\hline \multicolumn{9}{|c|}{ Leaf Elemental Ratios: } \\
\hline $\mathrm{Na}: \mathrm{K}$ & $29.47 * * * *$ & $12.84 * * * *$ & $93.24 * * * *$ & $7.66 * * * *$ & $11.02 * *$ & $3.84 *$ & $3.82 *$ & $1.71 \mathrm{~ns}$ \\
\hline $\mathrm{Fe}: \mathrm{K}$ & $234.3 * * * *$ & $157.1 * * * *$ & $235.8 * * * *$ & $56.38 * * *$ & $218.8 * * * *$ & $0.785 \mathrm{~ns}$ & $46.01 * * * *$ & $10.43 * * * *$ \\
\hline $\mathrm{Al}: \mathrm{K}$ & $58.74 * * * *$ & $44.62 * * * *$ & $250.6 * * * *$ & $61.43 * * *$ & $276.4 * * * *$ & $0.183 \mathrm{~ns}$ & $60.51 * * * *$ & $14.89 * * * *$ \\
\hline $\mathrm{Mn}: \mathrm{K}$ & $56.93 * * * *$ & $20.28 * *$ & $94.08 * * * *$ & $18.30 * * * *$ & $19.61 * * * *$ & $10.90 * * * *$ & $4.18 *$ & $1.33 \mathrm{~ns}$ \\
\hline
\end{tabular}




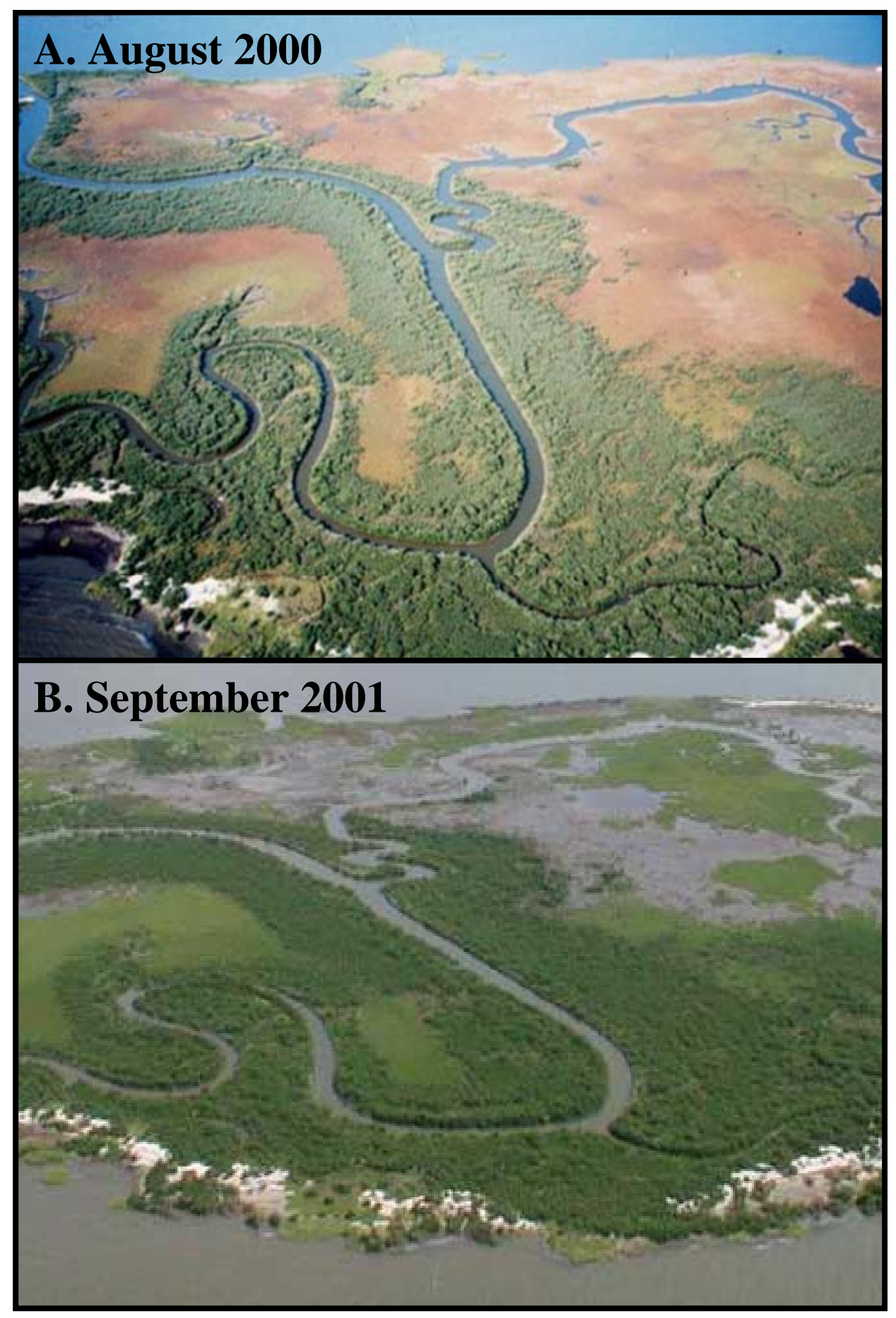

Figure 11. Aerial view of Pelican Island, La. showing healthy Avicennia germinans (black mangrove) stands alongside dying Spartina alterniflora (smooth cordgrass) marsh (brown color in A). Note transformation of S. alterniflora marsh to mudflat (B) one year after dieback. 


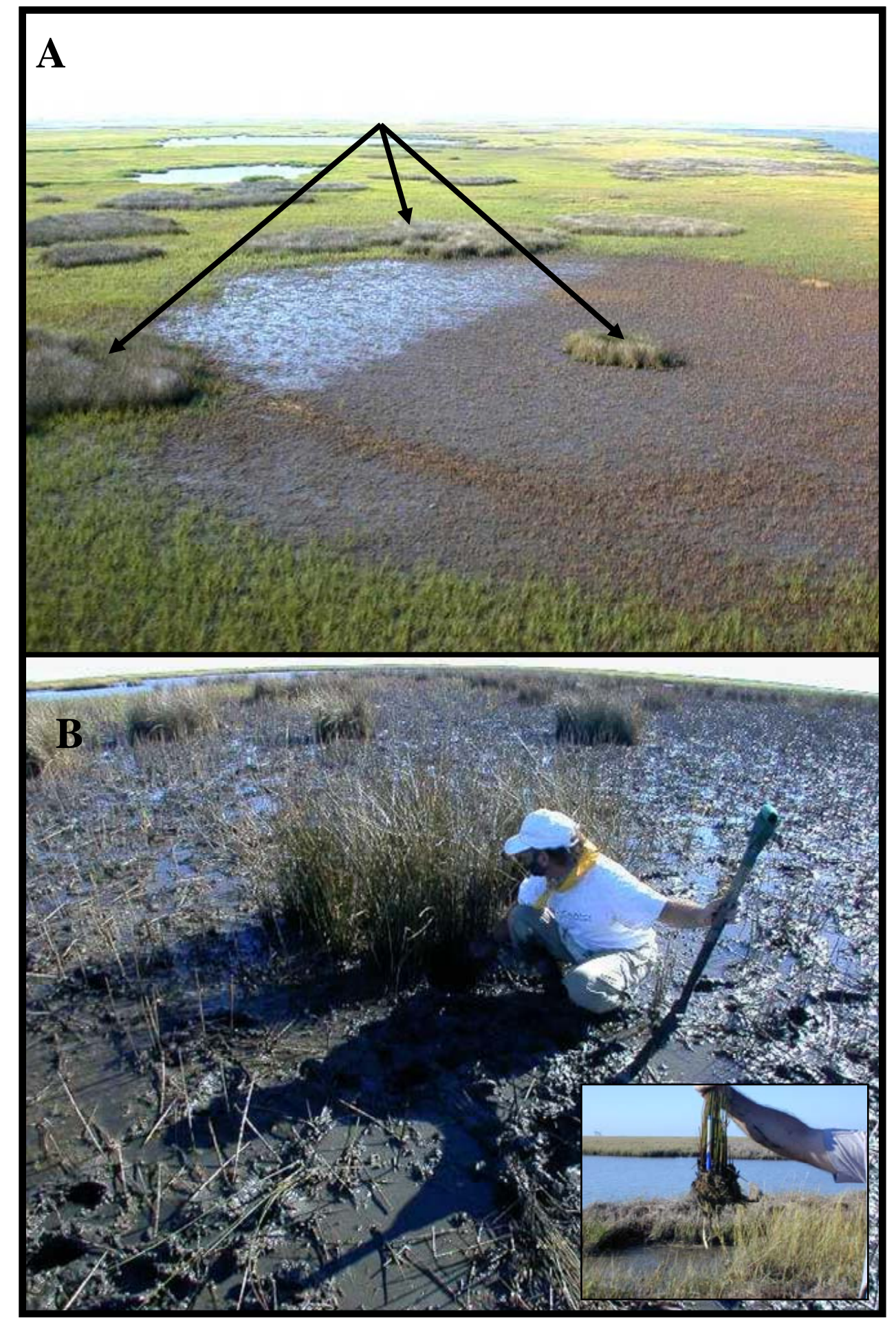

Figure 12. Aerial (A) and ground (B) views of healthy Juncus roemerianus (needlegrass rush) patches, indicated by arrows in upper panel, growing within areas of dead Spartina alterniflora (smooth cordgrass). Inset photograph in panel B illustrates a healthy but shallow root system of $J$. roemerianus excavated from the patch shown above. 


\section{Physicochemical Conditions}

Bay Junop

Salinity varied from 27 to $32 \mathrm{ppt}$ across healthy and dieback marsh zones at Bay Junop and was similar to that in the bay water and slightly higher than at Old Oyster Bayou (OOB) (fig. 13, table 4). The highest salinity (46 ppt) was found in the healthy mangrove zone (fig. 13). Soil pH remained near neutrality in all vegetation zones (fig. 13). Soil bulk density varied from 0.3 to $0.5 \mathrm{~g} \mathrm{~cm}^{-3}$ across marsh and mangrove zones and was higher on average than that at OOB (fig. 13). Soils became more reducing (i.e., less oxidized) with higher concentrations of sulfide with distance from open water (fig. $13)$.

Intensive Sites 1-21

Soil physicochemical characteristics varied over sites, zones, and time (figs. 1415, tables 5-7). Averaged over site and time, salinity varied from $20 \mathrm{ppt}$ in shoreline control marshes to $38 \mathrm{ppt}$ in regenerating marshes. Although significant, salinity was only slightly higher in interior dieback marshes (30 ppt) compared to adjacent shorelines with live vegetation (28 ppt) and was well within the tolerance limits of S. alterniflora (Hester and others, 1996). Porewater $\mathrm{pH}$ was near neutrality at all S. alternifloradominated marshes but was low ( 4) in the interior dieback marsh at site 1 (dominated by S. patens).

Soils at S. alterniflora sites were generally more reducing with higher sulfide concentrations in the marsh interior where the vegetation was dead compared to that at the shoreline. However, sulfide concentrations in interior dieback zones were similar to those at control marshes. Also, high redox potentials and low sulfide concentrations at the dieback site dominated by $S$. patens (site 1) indicated oxidizing conditions. Soil bulk density was lower and organic matter content was higher at control marshes compared to that at the dieback marshes (tables 6-7).

\section{Soil Elemental Concentrations}

Many of the soil elemental concentrations measured in August-October 2000 (tables 8-9) had correlations that exceeded 0.5 , a fact indicating that factor analysis could be used to assess patterns at dieback and control marshes. The first two eigenvalues for water- and acetate-extractable elements exceeded unity and explained 68 and 63 percent, respectively, of the variation in the overall data. For water-extractable elements, the first factor accounted for 53 percent of the total variation in the data and included elements associated with seawater $\mathrm{Ca}, \mathrm{K}, \mathrm{Mg}, \mathrm{Na}$ and $\mathrm{S}$ (table 10). The second factor, which accounted for an additional 15 percent of the variation, had high loadings of $\mathrm{Al}, \mathrm{Fe}$, and $\mathrm{P}$ (table 10). For acetate-extractable elements, the first factor, had high loadings of $\mathrm{Ca}, \mathrm{K}$, $\mathrm{Mg}, \mathrm{Na}, \mathrm{S}$, and $\mathrm{Al}$ and accounted for 48 percent of the total variation (table 10). The second factor, which accounted for an additional 15 percent of the variation, included two redox elements, Fe and Mn (table 10). 

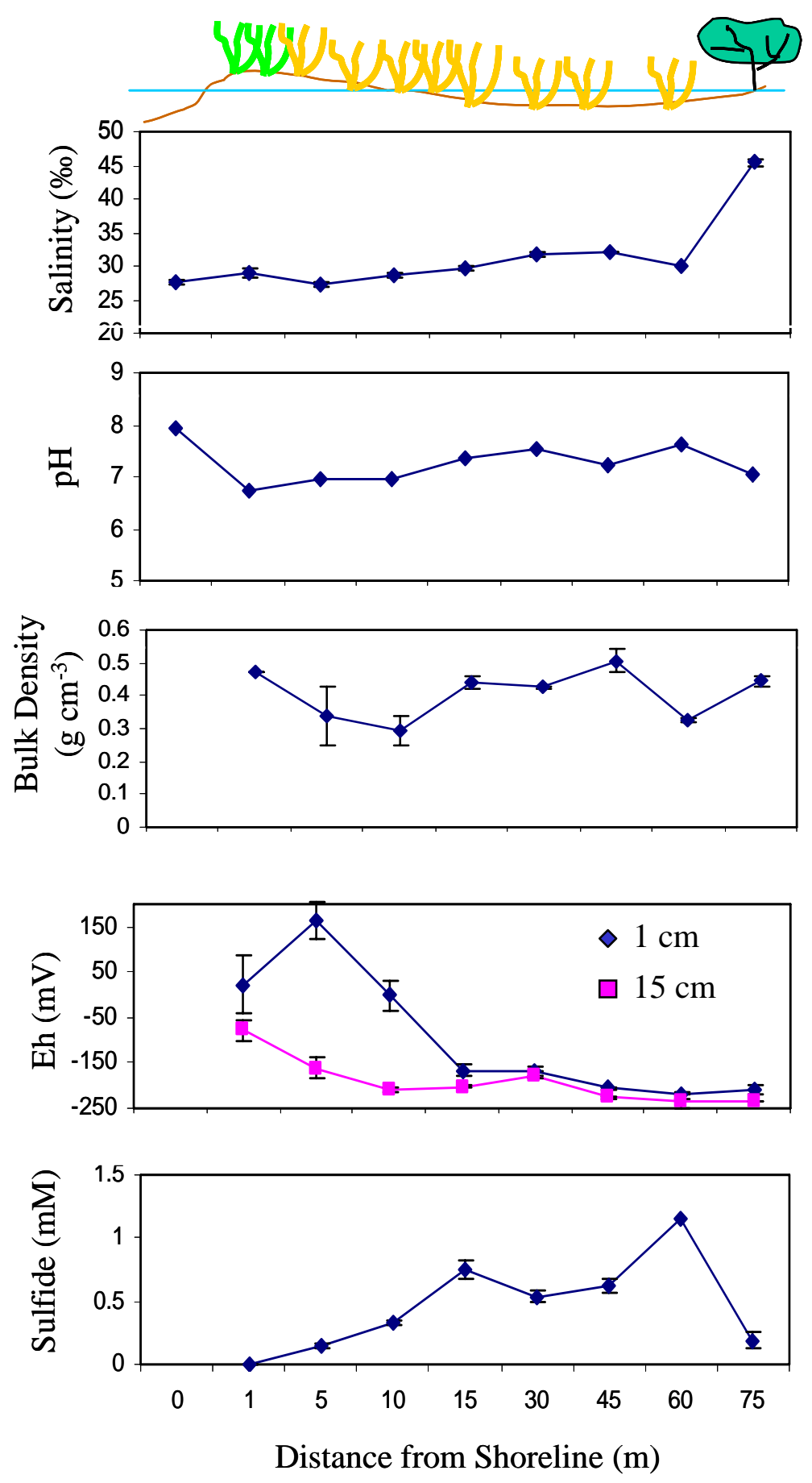

Figure 13. Soil conditions measured at Bay Junop site in June 2000. Transects traversed a dieback salt marsh dominated by Spartina alterniflora and terminated in a healthy mangrove stand. Solid lines indicate average value measured at a control marsh (Old Oyster Bayou). 
Table 4. ANOVA results for physicochemical variables measured at Bay Junop (BJ) and Old Oyster Bayou (OOB) in June 2000 where site (BJ and OOB) and zone within site (healthy shoreline (HS), dieback interior (DI), and mangrove (M)) are grouping factors. Values are the F-ratio or t-value (1 degree of freedom contrasts); significance is indicated by $*(\mathrm{p} \leq 0.05), * *(\mathrm{p} \leq 0.01), * * *(\mathrm{p} \leq$ $0.001), * * * *(\mathrm{p} \leq 0.0001)$, or $\mathrm{ns}$ (not significant).

\begin{tabular}{|c|c|c|c|c|c|}
\hline & \multicolumn{2}{|c|}{ Source of Variation: } & \multicolumn{3}{|c|}{ Contrasts: } \\
\hline & Site & Zone (Site) & HS vs DI & HS vs $\mathrm{M}$ & DI vs M \\
\hline \multicolumn{6}{|l|}{ Soil Variables: } \\
\hline Bulk density & $22.13 * * *$ & $3.16 \mathrm{~ns}$ & - & - & - \\
\hline $\mathrm{Eh}_{1}$ & $12.87 * *$ & $16.81 * * * *$ & $-9.55 * * * *$ & $6.07 * * * *$ & $0.408 \mathrm{~ns}$ \\
\hline $\mathrm{Eh}_{15}$ & $3.72 \mathrm{~ns}$ & $9.13 * * *$ & $-5.30 * * *$ & $3.31 * *$ & $0.982 \mathrm{~ns}$ \\
\hline Moisture & $6.37 *$ & $2.49 \mathrm{~ns}$ & - & - & - \\
\hline Salinity & $361 * * * *$ & $153 * * * *$ & $8.25 * * * *$ & $-35.2 * * * *$ & $-29.8 * * * *$ \\
\hline $\mathrm{pH}$ & $29.09 * * * *$ & $13.7 * * * *$ & $7.72 * * * *$ & $-1.46 \mathrm{~ns}$ & $3.29 * *$ \\
\hline Sulfide & - & $45.49 * * * *$ & $16.15 * * * *$ & $-0.487 \mathrm{~ns}$ & $9.44 * * * *$ \\
\hline
\end{tabular}




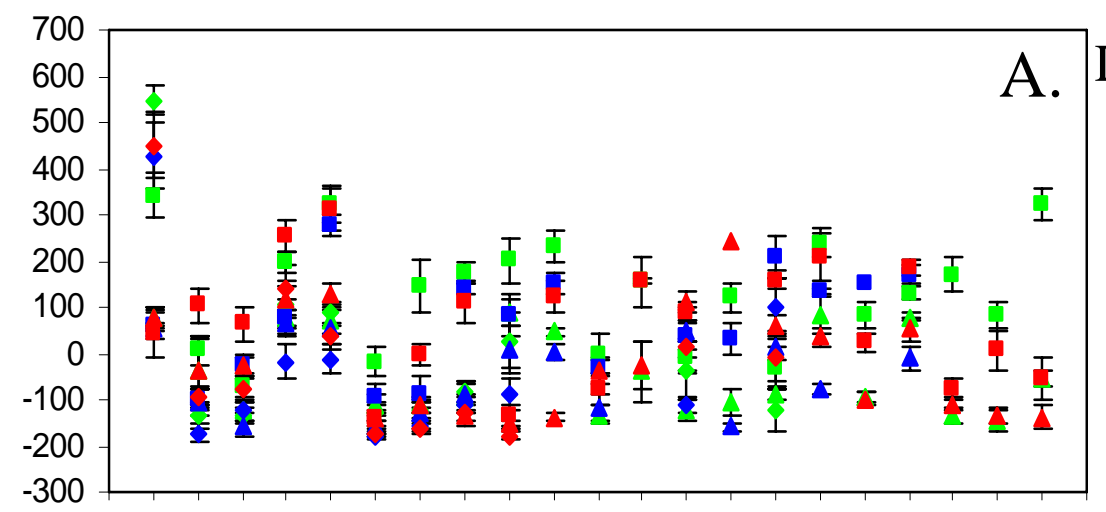

\section{Date/Zone: \\ $\diamond 08 / 00$ Shoreline \\ $\square$ 04/01 Shoreline \\ $\triangle 09 / 01$ Shoreline \\ $\diamond$ 08/00 Transition \\ $\square$ 04/01 Transition \\ $\triangle$ 09/01 Transition \\ $\diamond 08 / 00$ Interior \\ 04/01 Interior \\ $\Delta$ 09/01 Interior}
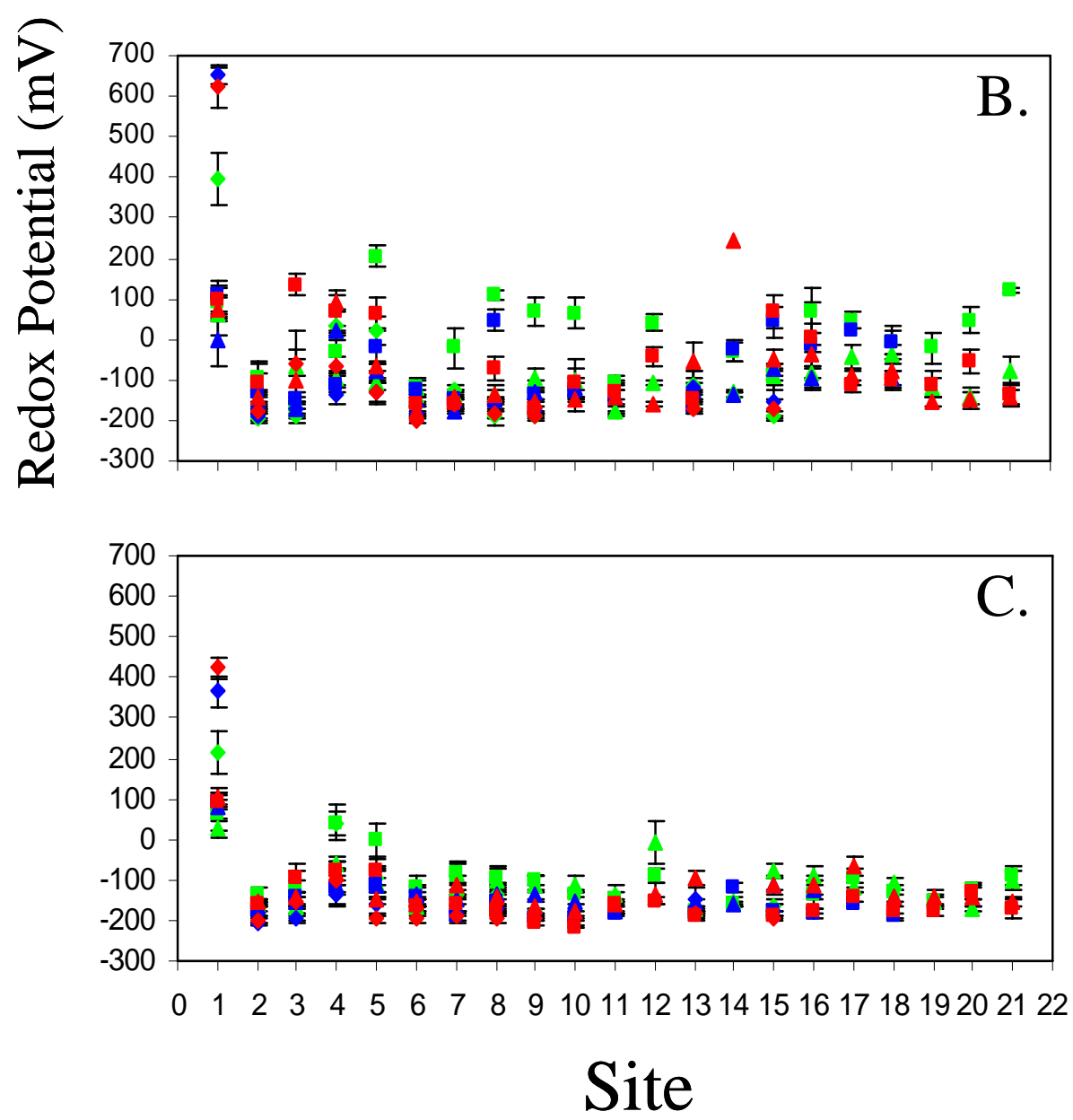

Figure 14. Soil redox potential measured at $1 \mathrm{~cm}(A), 15 \mathrm{~cm}(B)$, and $30 \mathrm{~cm}$ (C) depths in shoreline, transition, and interior zones of marshes dominated by Spartina patens (marshhay cordgrass) (site 1) or S. alterniflora (smooth cordgrass) (sites 2-21) on 3 dates. Values are the mean $\pm 1 \mathrm{SE}$ ( $\mathrm{n}=6$ at dieback sites 1-18 and at control sites 19-21) in August 2000 (08/00) and April 2001 (04/01), and n = 3 in September 2001(09/01). 

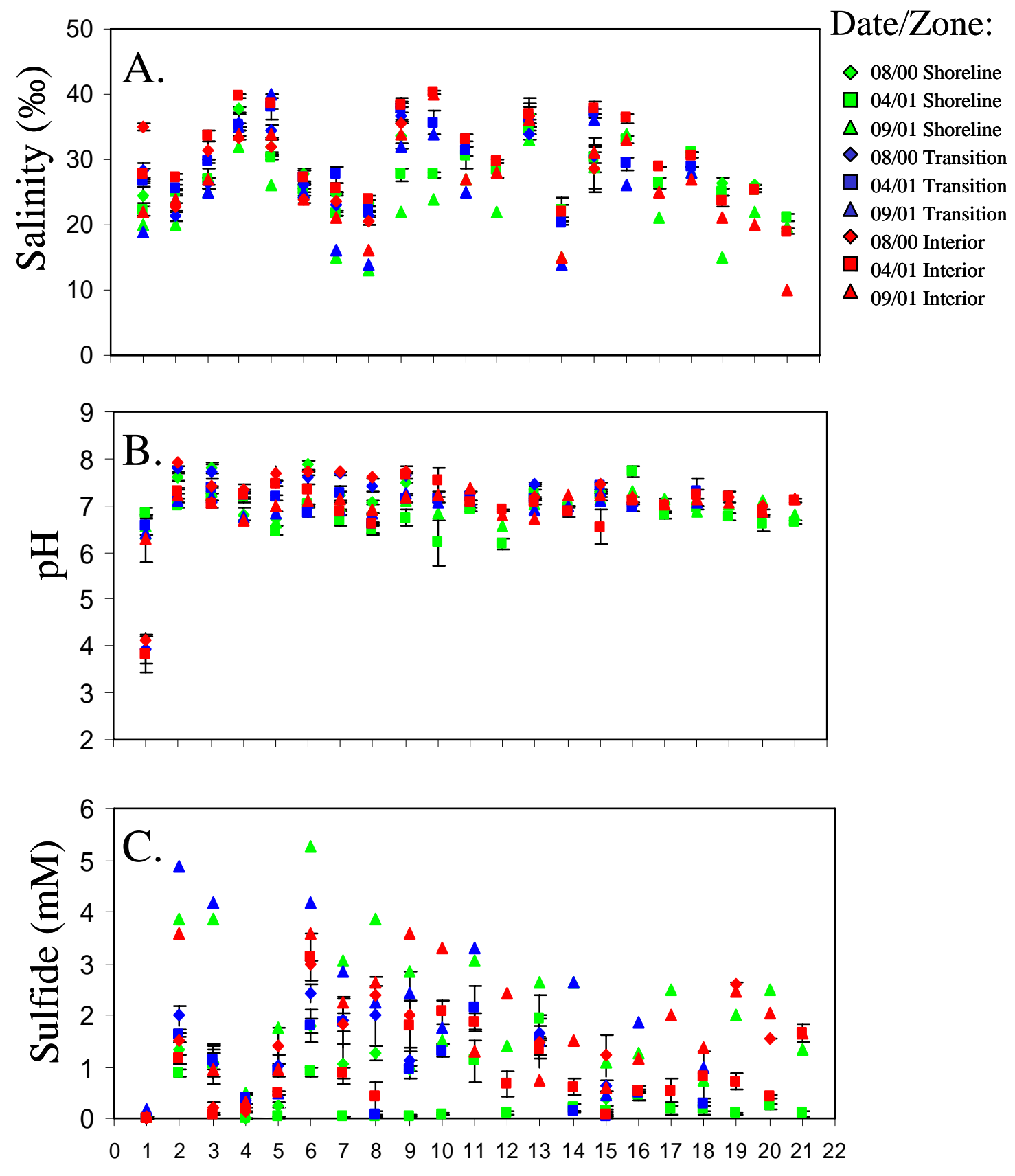

\section{Site}

Figure 15. Soil salinity (A), $\mathrm{pH}(\mathrm{B})$, and sulfide (C) measured in shoreline, transition, and interior zones of marshes dominated by Spartina patens (marshhay cordgrass) (site 1) or S. alterniflora (smooth cordgrass) (sites 2-21) on 3 dates. Values are the mean $\pm 1 \mathrm{SE}$ $(\mathrm{n}=3$ plots at dieback sites 1-18 and at control sites 19-21) in August $2000(08 / 00)$ and April 2001 (04/01), and single observations in September 2001(09/01). 
Table 5. Results of a repeated-measures ANOVA for soil variables measured at Spartina alterniflora (smooth cordgrass)-dominated dieback sites (2-18) where site, zone (healthy shoreline [HS], transition [T], dieback interior [DI]), and time (August 2000, April 2001, September 2001) were grouping factors. $1 \mathrm{df}$ contrasts are given where a significant Zone or Zone*Time effect was found. Values are the F-ratio, and significance is indicated by $*(\mathrm{p} \leq 0.05), * *(\mathrm{p} \leq 0.01), * * *(\mathrm{p} \leq 0.001), * * * *(\mathrm{p} \leq 0.0001)$, or ns (not significant).

\begin{tabular}{|c|c|c|c|c|c|c|}
\hline & \multicolumn{4}{|c|}{ Source of Variation: } & \multicolumn{2}{|l|}{ Contrasts: } \\
\hline & Site & Zone & Time & & Zone*Time & HS vs DI HS vs T \\
\hline \multicolumn{7}{|c|}{ Soil Variables: } \\
\hline Bulk density & $46.60 * * * *$ & $7.12 * *$ & $8.09 * *$ & $3.24 *$ & $8.22 * *$ & $12.45 * *$ \\
\hline $\mathrm{Eh}_{1}$ & $14.23 * * * *$ & $1.83 \mathrm{~ns}$ & $115.6 * * * *$ & $1.05 \mathrm{~ns}$ & - & - \\
\hline $\mathrm{Eh}_{15}$ & $8.45 * * * *$ & $1.76 \mathrm{~ns}$ & $24.40 * * * *$ & $2.17 \mathrm{~ns}$ & - & - \\
\hline $\mathrm{Eh}_{30}$ & $6.10 * * * *$ & $6.98 * *$ & $19.81 * * * *$ & $1.29 \mathrm{~ns}$ & $7.08 * *$ & $12.96 * * *$ \\
\hline Salinity & $34.32 * * * *$ & $9.17 * *$ & $41.60 * * * *$ & $2.98 *$ & $14.64 * *$ & $12.42 * *$ \\
\hline $\mathrm{pH}$ & $1.14 \mathrm{~ns}$ & $0.57 \mathrm{~ns}$ & $47.28 * * * *$ & $0.74 \mathrm{~ns}$ & - & - \\
\hline Sulfide & $6.31 * * *$ & $0.11 \mathrm{~ns}$ & $52.77 * * * *$ & $3.82 *$ & $8.91 * *$ & $3.41 *$ \\
\hline
\end{tabular}


Table 6. Summary of physicochemical conditions (averaged over site and time) measured in stands dominated by Spartina alterniflora. Values are given by site; zone (shoreline [S], transition [T], or interior [I]); and vegetative condition (healthy [H], dieback $[D]$, regenerating $[R]$, or control $[C)]$. Values are the mean and (1 SE).

\begin{tabular}{|c|c|c|c|c|c|c|c|c|c|c|c|}
\hline Site & Zone & Condition & $\mathrm{n}$ & $\mathrm{pH}$ & $\begin{array}{c}\text { Salinity } \\
(\% o)\end{array}$ & $\begin{array}{l}\text { Sulfide } \\
(\mathrm{mM})\end{array}$ & $\begin{array}{c}\mathrm{Eh}_{1} \\
(\mathrm{mV})\end{array}$ & $\begin{array}{l}\mathrm{Eh}_{15} \\
(\mathrm{mV})\end{array}$ & $\begin{array}{l}\mathrm{Eh}_{30} \\
(\mathrm{mV})\end{array}$ & $\begin{array}{l}\text { Bulk Density } \\
\quad\left(\mathrm{g} / \mathrm{cm}^{3}\right)\end{array}$ & $\begin{array}{c}\% \text { Organic } \\
\text { Matter }\end{array}$ \\
\hline $2-18$ & $S$ & $\mathrm{H}$ & 306 & $\begin{array}{l}7.03 \\
(0.04)\end{array}$ & $\begin{array}{r}28 \\
1\end{array}$ & $\begin{array}{c}0.947 \\
(0.107)\end{array}$ & $\begin{array}{c}29 \\
(10)\end{array}$ & $\begin{array}{c}-69 \\
(8)\end{array}$ & $\begin{array}{r}-118 \\
(5)\end{array}$ & $\begin{array}{c}0.38 \\
(0.02)\end{array}$ & $\begin{array}{l}17.7 \\
(1.6)\end{array}$ \\
\hline $2-18$ & $\mathrm{~T}$ & $\mathrm{D}$ & 306 & $\begin{array}{c}7.24 \\
(0.03)\end{array}$ & $\begin{array}{r}30 \\
1\end{array}$ & $\begin{array}{c}1.338 \\
(0.106)\end{array}$ & $\begin{array}{c}-8 \\
(10)\end{array}$ & $\begin{array}{r}-113 \\
(7)\end{array}$ & $\begin{array}{r}-162 \\
(4)\end{array}$ & $\begin{array}{c}0.34 \\
(0.02)\end{array}$ & $\begin{array}{l}17.9 \\
(1.2)\end{array}$ \\
\hline $2-18$ & I & $\mathrm{D}$ & 306 & $\begin{array}{c}7.25 \\
(0.04)\end{array}$ & $\begin{array}{r}31 \\
1\end{array}$ & $\begin{array}{c}1.312 \\
(0.104)\end{array}$ & $\begin{array}{c}19 \\
(10)\end{array}$ & $\begin{array}{c}-95 \\
(7)\end{array}$ & $\begin{array}{r}-156 \\
(4)\end{array}$ & $\begin{array}{c}0.34 \\
(0.02)\end{array}$ & $\begin{array}{l}17.8 \\
(1.3)\end{array}$ \\
\hline $15-16$ & $\mathrm{~S}$ & $\mathrm{D}$ & 36 & $\begin{array}{c}6.77 \\
(0.09)\end{array}$ & $\begin{array}{r}31 \\
1\end{array}$ & $\begin{array}{c}0.129 \\
(0.021)\end{array}$ & $\begin{array}{l}237 \\
(31)\end{array}$ & $\begin{array}{c}32 \\
(27)\end{array}$ & $\begin{array}{r}-126 \\
(30)\end{array}$ & $\begin{array}{c}0.36 \\
(0.02)\end{array}$ & $\begin{array}{l}15.6 \\
(0.7)\end{array}$ \\
\hline $19-21$ & $S$ & $\mathrm{C}$ & 54 & $\begin{array}{c}6.79 \\
(0.06)\end{array}$ & $\begin{array}{r}20 \\
1\end{array}$ & $\begin{array}{c}0.863 \\
(0.267)\end{array}$ & $\begin{array}{c}90 \\
(35)\end{array}$ & $\begin{array}{c}-5 \\
(21)\end{array}$ & $\begin{array}{r}-129 \\
(10)\end{array}$ & $\begin{array}{c}0.24 \\
(0.01)\end{array}$ & $\begin{array}{l}24.0 \\
(2.6)\end{array}$ \\
\hline $19-21$ & I & $\mathrm{C}$ & 54 & $\begin{array}{c}7.05 \\
(0.04)\end{array}$ & $\begin{array}{r}23 \\
1\end{array}$ & $\begin{array}{c}1.579 \\
(0.202)\end{array}$ & $\begin{array}{l}-70 \\
(17)\end{array}$ & $\begin{array}{r}-116 \\
(13)\end{array}$ & $\begin{array}{r}-154 \\
(8)\end{array}$ & $\begin{array}{c}0.13 \\
(0.01)\end{array}$ & $\begin{array}{l}41.7 \\
(3.4)\end{array}$ \\
\hline $4-6$ & I & $\mathrm{R}$ & 18 & $\begin{array}{c}7.32 \\
(0.07)\end{array}$ & $\begin{array}{r}38 \\
1\end{array}$ & $\begin{array}{c}0.565 \\
(0.169)\end{array}$ & $\begin{array}{l}136 \\
(28)\end{array}$ & $\begin{array}{l}-78 \\
(25)\end{array}$ & $\begin{array}{r}-140 \\
(20)\end{array}$ & - & $\begin{array}{l}11.5 \\
(0.6)\end{array}$ \\
\hline
\end{tabular}


Table 7. Summary of physicochemical conditions (averaged over site and time) measured in stands dominated by Juncus roemerianus (needlegrass rush) and Spartina patens(marshhay cordgrass). Values are given by dominant species, site; zone (shoreline [S], transition [T], or interior [I]); and vegetative condition (healthy $[\mathrm{H}]$ or dieback [D]). Values are the mean and (1 SE).

\begin{tabular}{|c|c|c|c|c|c|c|c|c|c|c|c|}
\hline Site & Zone & ndition & $\mathrm{n}$ & $\mathrm{pH}$ & $\begin{array}{c}\text { Salinity } \\
(\% o)\end{array}$ & $\begin{array}{l}\text { Sulfide } \\
(\mathrm{mM})\end{array}$ & $\begin{array}{c}\mathrm{Eh}_{1} \\
(\mathrm{mV})\end{array}$ & $\begin{array}{c}\mathrm{Eh}_{15} \\
(\mathrm{mV})\end{array}$ & $\begin{array}{c}\mathrm{Eh}_{30} \\
(\mathrm{mV})\end{array}$ & $\begin{array}{l}\text { Bulk Density } \\
\left(\mathrm{g} / \mathrm{cm}^{3}\right)\end{array}$ & $\begin{array}{c}\% \text { Organic } \\
\text { Matter }\end{array}$ \\
\hline \multicolumn{12}{|c|}{ Juncus roemerianus } \\
\hline 16 & I & $\mathrm{H}$ & 24 & $\begin{array}{c}7.11 \\
(0.11)\end{array}$ & $\begin{array}{r}31 \\
0\end{array}$ & $\begin{array}{c}1.217 \\
(0.178)\end{array}$ & $\begin{array}{l}189 \\
(42)\end{array}$ & $\begin{array}{r}-116 \\
(31)\end{array}$ & $\begin{array}{r}-169 \\
(8)\end{array}$ & $\begin{array}{c}0.24 \\
(0.02)\end{array}$ & $\begin{array}{l}16.0 \\
(1.0)\end{array}$ \\
\hline \multicolumn{12}{|c|}{ Spartina patens } \\
\hline 1 & $\mathrm{~S}$ & $\mathrm{H}$ & 18 & $\begin{array}{c}6.57 \\
(0.22)\end{array}$ & $\begin{array}{r}23 \\
1\end{array}$ & $\begin{array}{c}0.014 \\
(0.011)\end{array}$ & $\begin{array}{l}371 \\
(52)\end{array}$ & $\begin{array}{l}208 \\
(51)\end{array}$ & $\begin{array}{l}115 \\
(34)\end{array}$ & $\begin{array}{c}0.44 \\
(0.04)\end{array}$ & $\begin{array}{l}11.2 \\
(2.0)\end{array}$ \\
\hline 1 & $\mathrm{~T}$ & $\mathrm{D}$ & 18 & $\begin{array}{c}5.41 \\
(0.54)\end{array}$ & $\begin{array}{r}26 \\
1\end{array}$ & $\begin{array}{c}0.026 \\
(0.026)\end{array}$ & $\begin{array}{l}207 \\
(57)\end{array}$ & $\begin{array}{l}304 \\
(80)\end{array}$ & $\begin{array}{l}200 \\
(40)\end{array}$ & $\begin{array}{c}0.55 \\
(0.04)\end{array}$ & $\begin{array}{c}8.5 \\
(0.9)\end{array}$ \\
\hline 1 & I & $\mathrm{D}$ & 18 & $\begin{array}{c}4.29 \\
(0.37)\end{array}$ & $\begin{array}{r}30 \\
2\end{array}$ & $\begin{array}{c}0.005 \\
(0.005)\end{array}$ & $\begin{array}{l}213 \\
(62)\end{array}$ & $\begin{array}{l}303 \\
(73)\end{array}$ & $\begin{array}{l}229 \\
(45)\end{array}$ & $\begin{array}{c}0.57 \\
(0.04)\end{array}$ & $\begin{array}{c}6.6 \\
(1.1)\end{array}$ \\
\hline
\end{tabular}


Table 8. Water-extractable soil elemental concentrations $(\mathrm{mg} / \mathrm{kg})$ measured in August 2000 at dieback and reference marshes dominated by Spartina spp. Values are given by site (1-20), zone (shoreline [S], transition [T], or interior [I]); and vegetative condition (healthy $[\mathrm{H}]$, dieback $[\mathrm{D}]$, regenerating $[\mathrm{R}]$ ) or control $[\mathrm{C}]$ ). Three plots were sampled at each site/zone/condition combination. Values are the mean and (1 SE).

$\begin{array}{cccccccccccccccc}\text { Site } & \text { Zone } & \text { Condition } & \mathrm{n} & \mathrm{Al} & \mathrm{Ca} & \mathrm{Cu} & \mathrm{Fe} & \mathrm{K} & \mathrm{Mg} & \mathrm{Mn} & \mathrm{Na} & \mathrm{P} & \mathrm{S} & \mathrm{Zn} \\ 1-18 & \mathrm{~S} & \mathrm{H} & 54 & 0.56 & 436.6 & 0.013 & 0.25 & 321.0 & 808.3 & 0.85 & 8067 & 4.63 & 2308.2 & 0.40 \\ & & & & (0.14) & (30.5) & (0.003) & (0.10) & (19.0) & (70.0) & (0.17) & (687) & (0.66) & (292.3) & (0.09) \\ 1-18 & \mathrm{~T} & \mathrm{D} & 54 & 0.73 & 463.0 & 0.004 & 0.90 & 295.0 & 868.6 & 1.66 & 8208 & 5.39 & 2173.1 & 0.31 \\ & & & & (0.25) & (19.1) & (0.001) & (0.43) & (10.1) & (42.1) & (0.38) & (509) & (0.93) & (214.9) & (0.06) \\ 1-18 & \mathrm{I} & \mathrm{D} & 54 & 0.67 & 482.8 & 0.021 & 0.13 & 430.3 & 1285.6 & 0.93 & 13251 & 6.41 & 2339.1 & 0.28 \\ & & & & (0.23) & (24.6) & (0.004) & (0.06) & (34.4) & (129.9) & (0.20) & (1386) & (1.18) & (222.2) & (0.05) \\ 6 & \mathrm{I} & \mathrm{R} & 3 & 0.05 & 680.7 & 0.005 & 0.16 & 553.3 & . & 0.76 & . & 0.04 & 5978.4 & 0.30 \\ & & & & (0.02) & (29.0) & (0.001) & (0.08) & (31.7) & . & (0.36) & . & (0.01) & (756.8) & (0.09) \\ 19-20 & \mathrm{I} & \mathrm{C} & 6 & 1.46 & 618.9 & 0.070 & 0.00 & 799.3 & 2138.3 & 0.93 & 19430 & 20.99 & 2229.1 & 0.92 \\ & & & & (0.39) & (65.9) & (0.016) & (0.00) & (103.3) & (237.8) & (0.23) & (2397) & (1.87) & (272.0) & (0.57)\end{array}$


Table 9. Ammonium acetate-extractable soil elemental concentrations (mg/kg) measured in August 2000 at dieback and reference marshes dominated by Spartina spp. Values are given by site (1-20), zone (shoreline [S], transition [T], or interior [I]); and vegetative condition (healthy $[\mathrm{H}]$, dieback $[\mathrm{D}]$, regenerating $[\mathrm{R}]$ or control $[\mathrm{C}]$ ). Three plots were sampled at each site/zone/condition combination. Values are the mean and $(1 \mathrm{SE})$. Note that some elements were below detection limits $(<\mathrm{DL})$.

\begin{tabular}{|c|c|c|c|c|c|c|c|c|c|c|c|c|c|c|}
\hline$\underline{\text { Site }}$ & Zone & Condition & $\mathrm{n}$ & $\underline{\mathrm{Al}}$ & $\mathrm{Ca}$ & $\mathrm{Cu}$ & $\mathrm{Fe}$ & $\mathrm{K}$ & $\mathrm{Mg}$ & $\mathrm{Mn}$ & $\mathrm{Na}$ & $\mathrm{P}$ & $S$ & $\mathrm{Zn}$ \\
\hline $1-18$ & S & $\mathrm{H}$ & 54 & $\begin{array}{c}0.90 \\
(0.11)\end{array}$ & $\begin{array}{l}777.6 \\
(54.6)\end{array}$ & $\begin{array}{c}0.116 \\
(0.020)\end{array}$ & $\begin{array}{c}0.198 \\
(0.063)\end{array}$ & $\begin{array}{l}791.83 \\
(57.67)\end{array}$ & $\begin{array}{r}1306.7 \\
(97.9)\end{array}$ & $\begin{array}{c}3.65 \\
(0.70)\end{array}$ & $\begin{array}{l}4474 \\
(442)\end{array}$ & $\begin{array}{c}0.84 \\
(0.10)\end{array}$ & $\begin{array}{l}828.7 \\
(67.8)\end{array}$ & $\begin{array}{c}2.03 \\
(0.33)\end{array}$ \\
\hline $1-18$ & $\mathrm{~T}$ & $\mathrm{D}$ & 54 & $\begin{array}{c}0.84 \\
(0.08)\end{array}$ & $\begin{array}{l}838.1 \\
(78.3)\end{array}$ & $\begin{array}{c}0.059 \\
(0.012)\end{array}$ & $\begin{array}{c}0.164 \\
(0.053)\end{array}$ & $\begin{array}{l}749.75 \\
(62.81)\end{array}$ & $\begin{array}{c}1212.6 \\
(114.3)\end{array}$ & $\begin{array}{c}4.52 \\
(0.66)\end{array}$ & $\begin{array}{l}4201 \\
(454)\end{array}$ & $\begin{array}{c}0.64 \\
(0.06)\end{array}$ & $\begin{array}{l}867.0 \\
(67.1)\end{array}$ & $\begin{array}{c}2.03 \\
(0.47)\end{array}$ \\
\hline $1-18$ & I & $\mathrm{D}$ & 54 & $\begin{array}{c}0.99 \\
(0.11)\end{array}$ & $\begin{array}{l}914.0 \\
(76.4)\end{array}$ & $\begin{array}{c}0.150 \\
(0.041)\end{array}$ & $\begin{array}{c}0.173 \\
(0.060)\end{array}$ & $\begin{array}{c}815.27 \\
(61.13)\end{array}$ & $\begin{array}{l}1488.9 \\
(124.2)\end{array}$ & $\begin{array}{c}4.29 \\
(0.68)\end{array}$ & $\begin{array}{l}4588 \\
(491)\end{array}$ & $\begin{array}{c}1.30 \\
(0.22)\end{array}$ & $\begin{array}{l}911.2 \\
(77.3)\end{array}$ & $\begin{array}{c}3.37 \\
(0.85)\end{array}$ \\
\hline 6 & I & $\mathrm{R}$ & 3 & $\begin{array}{c}0.34 \\
(0.11)\end{array}$ & $\begin{array}{l}447.1 \\
(42.0)\end{array}$ & $<$ DL & $<\mathrm{DL}$ & $\begin{array}{l}536.84 \\
(23.05)\end{array}$ & $\begin{array}{l}870.3 \\
(77.1)\end{array}$ & $\begin{array}{c}6.45 \\
(0.78)\end{array}$ & $\begin{array}{l}2787 \\
(239)\end{array}$ & $\begin{array}{c}0.50 \\
(0.22)\end{array}$ & $\begin{array}{c}861.4 \\
(119.2)\end{array}$ & $<\mathrm{DL}$ \\
\hline $19-20$ & I & $\mathrm{D}$ & 6 & $\begin{array}{c}2.01 \\
(0.22)\end{array}$ & $\begin{array}{c}1672.8 \\
(181.1)\end{array}$ & $\begin{array}{c}0.340 \\
(0.083)\end{array}$ & $\begin{array}{c}0.100 \\
(0.050)\end{array}$ & $\begin{array}{c}887.62 \\
(48.98)\end{array}$ & $\begin{array}{c}2680.0 \\
(179.6)\end{array}$ & $\begin{array}{c}3.06 \\
(0.42)\end{array}$ & $\begin{array}{c}7835 \\
(1097)\end{array}$ & $\begin{array}{c}4.64 \\
(2.67)\end{array}$ & $\begin{array}{l}1169.3 \\
(105.9)\end{array}$ & $\begin{array}{l}12.55 \\
(3.89)\end{array}$ \\
\hline
\end{tabular}


Table 10. Factor analysis of soil elemental concentrations measured at all sites (1-21) and zones (healthy shoreline [HS], transition [T], dieback interior [DI], dieback shoreline [DS], regenerating [R], control shoreline [CS], control interior [CI]) in August 2000. Principal component analysis was used to reduce the number of variables and multicollinearity. The rotated factor pattern is given for water- and ammonium acetate-extracted elements (see text for interpretation of factors). Individual factor scores were subjected to ANOVA with site and zone (nested within site) as grouping factors. F-ratios for main effects and 1 DF contrasts are given below the factor patterns; significance is indicated by $*(\mathrm{p} \leq 0.05), * *(\mathrm{p} \leq 0.01), * * *(\mathrm{p} \leq 0.001), * * * *(\mathrm{p} \leq 0.0001)$, or ns (not significant).

\begin{tabular}{|c|c|c|c|c|}
\hline \multirow[t]{2}{*}{ Extraction: } & \multicolumn{2}{|c|}{ Water } & \multicolumn{2}{|c|}{ Ammonium Acetate } \\
\hline & Factor 1 & Factor 2 & Factor 1 & Factor 2 \\
\hline $\mathrm{Al}$ & 0.41 & 0.70 & 0.70 & 0.46 \\
\hline $\mathrm{Ca}$ & 0.96 & 0.07 & 0.84 & -0.17 \\
\hline $\mathrm{Cu}$ & 0.18 & 0.51 & 0.50 & -0.16 \\
\hline $\mathrm{Fe}$ & -0.10 & 0.68 & 0.02 & 0.78 \\
\hline $\mathrm{K}$ & 0.97 & 0.00 & 0.87 & -0.20 \\
\hline $\mathrm{Mg}$ & 0.98 & 0.09 & 0.93 & -0.16 \\
\hline $\mathrm{Mn}$ & 0.63 & 0.07 & -0.27 & 0.79 \\
\hline $\mathrm{Na}$ & 0.96 & 0.05 & 0.91 & -0.20 \\
\hline $\mathrm{P}$ & -0.05 & 0.57 & 0.56 & 0.13 \\
\hline S & 0.98 & 0.06 & 0.73 & 0.18 \\
\hline $\mathrm{Zn}$ & 0.68 & 0.34 & 0.65 & -0.15 \\
\hline $\begin{array}{l}\text { Cumulative percent } \\
\text { of variance explained } \\
\text { ANOVA Source: }\end{array}$ & 53 & 68 & 48 & 63 \\
\hline Site & $22.31 * * * *$ & $3.10 * * * *$ & $38.18 * * * *$ & $6.05 * * * *$ \\
\hline Zone (site) & $1.01 \mathrm{~ns}$ & $1.84 * *$ & $2.27 * * *$ & $1.41 \mathrm{~ns}$ \\
\hline \multicolumn{5}{|l|}{ Contrasts: } \\
\hline$\overline{\text { HS vs. DI }}$ & - & $1.82 \mathrm{~ns}$ & $10.23 * *$ & - \\
\hline HS vs. T & - & $4.71^{*}$ & $0.11 \mathrm{~ns}$ & - \\
\hline DI vs. CI & - & $5.38 *$ & $76.22 * * * *$ & - \\
\hline Dieback vs. Control2S & $* * * *$ & $103.8 * * * *$ & $0.18 \mathrm{~ns}$ & \\
\hline
\end{tabular}


Water and acetate-extractable factor patterns for soil elements measured in April 2001 (tables 11-13) were similar to those found in August 2000. Acid-extractable elements were additionally measured in April 2001, and two factors were extracted from the data: the first factor with high loadings of $\mathrm{Ca}, \mathrm{K}, \mathrm{Mg}, \mathrm{Na}$, and $\mathrm{S}$ accounted for 49 percent of total variation and a second factor (23 percent of total variation) with high loadings of $\mathrm{Al}, \mathrm{Cu}$, and $\mathrm{Fe}$ (table 14). When factor scores were subjected to ANOVA, significant differences were found between dieback and control marshes for the factor with high loadings of metals (acid-extractable $\mathrm{Al}$ and $\mathrm{Fe}$ ) (table 14). When acidextractable concentrations of $\mathrm{Fe}$ and $\mathrm{Al}$ were individually assessed, values were higher at dieback marshes compared to control marshes but were not different between healthy shoreline and dieback interior zones within dieback marshes (fig. 16, table 15).

Similarly, pyrite concentrations were significantly higher at dieback compared to those at control marshes, but they were not different across zones within dieback marshes (fig. 17, table 15). These results demonstrate that the potential for soil acidification and release of potentially toxic metals such as Fe and Al was significantly higher at dieback marshes, but was similar within dieback marshes. The similarity of values within dieback marshes (i.e., shoreline, transition, and dieback interior) further suggests that if acidification and/or toxic metals caused plant mortality, spatial variation in hydrology or some other factor may have ameliorated effects along shorelines where plants were frequently inundated by tides.

\section{Soil Acidification Potential}

When soils from dieback marshes were subjected in the laboratory to oxidizing conditions, $\mathrm{pH}$ decreased significantly from near neutrality to 4.7 in $23 \mathrm{~d}$, whereas soils from control marshes did not change significantly (fig. 18). The $\mathrm{pH}$ of both dieback and control soils maintained under reducing conditions remained above 6.5. These results confirmed the potential for acidification of dieback soils.

\section{Plant Elemental Concentrations}

Elemental concentrations in leaf tissues were also examined to determine if plant uptake of potentially toxic metals or cations was higher in dieback marshes (tables 1619). As for soil concentrations, factor analysis was used to reduce the number of variables and problems of multicollinearity. For elements measured in S. alterniflora leaves in August-October 2000 and April 2001, three factors were extracted from the data, whereas four factors were extracted from the September 2001 data (table 20). Factor patterns of elements generally reflected processes controlling external soil concentrations and plant uptake. In August 2000, plant elemental composition was dominated by three factors: a factor dominated by divalent cations $\left(\mathrm{Ca}^{2+}, \mathrm{Mg}^{2+}\right)$, a second factor dominated by metals $\left(\mathrm{Fe}^{2+}, \mathrm{Al}^{3+}\right)$, and a third factor with a high loading of $\mathrm{Na}^{+}$. In April 2001, the same factor patterns were extracted from the data, except that $\mathrm{Al}, \mathrm{Fe}$, and $\mathrm{Zn}$ negatively loaded on factor 1 and that $\mathrm{K}$ loaded with $\mathrm{Na}$ on factor 3 . In September 2001, three factors were extracted that were similar to previous dates plus a fourth factor with high loading of $\mathrm{K}^{+}$. 
Table 11. Water-extractable soil elemental concentrations $(\mathrm{mg} / \mathrm{kg})$ measured in April 2001 at dieback and reference marshes dominated by Spartina spp. Values are given by site (1-21), zone (shoreline [S], transition [T], or interior [I]), and vegetative condition (healthy $[\mathrm{H}]$, dieback $[\mathrm{D}]$, regenerating $[\mathrm{R}]$ or control $[\mathrm{C}]$ ). Three plots were sampled at each site/zone/condition combination. Values are the mean and (1 SE). Note that some elements were below detection limits $(<\mathrm{DL})$.

\begin{tabular}{|c|c|c|c|c|c|c|c|c|c|c|c|c|c|c|}
\hline Site & Zone & Condition & $\mathrm{n}$ & $\underline{\mathrm{Al}}$ & $\mathrm{Ca}$ & $\mathrm{Cu}$ & $\mathrm{Fe}$ & $\mathrm{K}$ & $\mathrm{Mg}$ & $\mathrm{Mn}$ & $\mathrm{Na}$ & $\mathrm{P}$ & $\mathrm{S}$ & $\mathrm{Zn}$ \\
\hline $1-18$ & $\mathrm{~S}$ & $\mathrm{H}$ & 48 & $\begin{array}{c}1.01 \\
(0.20)\end{array}$ & $\begin{array}{l}492.9 \\
(62.7)\end{array}$ & $\begin{array}{c}0.07 \\
(0.01)\end{array}$ & $\begin{array}{c}0.37 \\
(0.14)\end{array}$ & $\begin{array}{l}521.2 \\
(61.9)\end{array}$ & $\begin{array}{l}1202 \\
(142)\end{array}$ & $\begin{array}{c}2.91 \\
(0.54)\end{array}$ & $\begin{array}{l}11358 \\
(1233)\end{array}$ & $\begin{array}{c}0.70 \\
(0.09)\end{array}$ & $\begin{array}{l}1794 \\
(222)\end{array}$ & $\begin{array}{c}0.76 \\
(0.11)\end{array}$ \\
\hline $1-18$ & $\mathrm{~T}$ & $\mathrm{D}$ & 48 & $\begin{array}{c}0.49 \\
(0.09)\end{array}$ & $\begin{array}{l}421.1 \\
(65.6)\end{array}$ & $\begin{array}{c}0.06 \\
(0.01)\end{array}$ & $\begin{array}{c}0.17 \\
(0.06)\end{array}$ & $\begin{array}{c}485.7 \\
(66.4)\end{array}$ & $\begin{array}{l}1074 \\
(145)\end{array}$ & $\begin{array}{c}2.55 \\
(0.67)\end{array}$ & $\begin{array}{l}10419 \\
(1329)\end{array}$ & $\begin{array}{c}0.74 \\
(0.07)\end{array}$ & $\begin{array}{l}1500 \\
(209)\end{array}$ & $\begin{array}{c}0.72 \\
(0.12)\end{array}$ \\
\hline $1-18$ & I & $\mathrm{D}$ & 54 & $\begin{array}{c}0.82 \\
(0.14)\end{array}$ & $\begin{array}{l}524.1 \\
(73.8)\end{array}$ & $\begin{array}{c}0.07 \\
(0.01)\end{array}$ & $\begin{array}{c}0.20 \\
(0.09)\end{array}$ & $\begin{array}{l}563.8 \\
(69.9)\end{array}$ & $\begin{array}{l}1326 \\
(177)\end{array}$ & $\begin{array}{c}5.38 \\
(1.69)\end{array}$ & $\begin{array}{l}12546 \\
(1568)\end{array}$ & $\begin{array}{c}0.79 \\
(0.10)\end{array}$ & $\begin{array}{l}1801 \\
(233)\end{array}$ & $\begin{array}{c}0.95 \\
(0.17)\end{array}$ \\
\hline $15-16$ & $S$ & $\mathrm{D}$ & 6 & $\begin{array}{c}0.65 \\
(0.14)\end{array}$ & $\begin{array}{l}527.7 \\
(53.6)\end{array}$ & $\begin{array}{c}0.09 \\
(0.02)\end{array}$ & $<\mathrm{DL}$ & $\begin{array}{l}611.5 \\
(47.4)\end{array}$ & $\begin{array}{l}1221 \\
(130)\end{array}$ & $\begin{array}{c}6.66 \\
(1.36)\end{array}$ & $\begin{array}{l}11945 \\
(1125)\end{array}$ & $\begin{array}{c}0.26 \\
(0.06)\end{array}$ & $\begin{array}{l}2227 \\
(320)\end{array}$ & $\begin{array}{c}1.27 \\
(0.60)\end{array}$ \\
\hline $19-21$ & $S$ & $\mathrm{C}$ & 9 & $\begin{array}{c}1.73 \\
(0.46)\end{array}$ & $\begin{array}{c}767.4 \\
(119.4)\end{array}$ & $\begin{array}{c}0.02 \\
(0.00)\end{array}$ & $\begin{array}{c}0.48 \\
(0.35)\end{array}$ & $\begin{array}{l}720.9 \\
(69.4)\end{array}$ & $\begin{array}{l}1532 \\
(185)\end{array}$ & $\begin{array}{c}6.47 \\
(1.67)\end{array}$ & $\begin{array}{l}15509 \\
(1497)\end{array}$ & $\begin{array}{c}1.50 \\
(0.44)\end{array}$ & $\begin{array}{l}2502 \\
(292)\end{array}$ & $\begin{array}{c}0.87 \\
(0.34)\end{array}$ \\
\hline $19-21$ & I & $\mathrm{C}$ & 9 & $\begin{array}{c}2.33 \\
(0.71)\end{array}$ & $\begin{array}{l}1088.9 \\
(171.2)\end{array}$ & $\begin{array}{c}0.08 \\
(0.01)\end{array}$ & $<\mathrm{DL}$ & $\begin{array}{c}958.0 \\
(152.4)\end{array}$ & $\begin{array}{l}2351 \\
(439)\end{array}$ & $\begin{array}{c}3.12 \\
(1.00)\end{array}$ & $\begin{array}{l}23289 \\
(3689)\end{array}$ & $\begin{array}{c}1.93 \\
(0.40)\end{array}$ & $\begin{array}{l}2964 \\
(591)\end{array}$ & $\begin{array}{c}1.77 \\
(0.46)\end{array}$ \\
\hline 4-6 & I & $\mathrm{R}$ & 9 & $\begin{array}{c}0.37 \\
(0.19)\end{array}$ & $\begin{array}{l}181.87 \\
(28.5)\end{array}$ & $\begin{array}{c}0.09 \\
(0.02)\end{array}$ & 0.27 & $\begin{array}{l}240.9 \\
(20.2)\end{array}$ & $\begin{array}{l}583 \\
(52)\end{array}$ & $\begin{array}{c}0.82 \\
(0.43)\end{array}$ & $\begin{array}{l}5856 \\
(348)\end{array}$ & $\begin{array}{c}1.20 \\
(0.15)\end{array}$ & $\begin{array}{c}732 \\
(106)\end{array}$ & $\begin{array}{c}0.32 \\
(0.10)\end{array}$ \\
\hline
\end{tabular}


Table 12. Ammonium acetate-extractable soil elemental concentrations ( $\mathrm{mg} / \mathrm{kg})$ measured in April 2001 at dieback and reference marshes dominated by Spartina spp. Values are given by site (1-21), zone (shoreline [S], transition [T], or interior [I]), and vegetative condition (healthy $[\mathrm{H}]$, dieback $[\mathrm{D}]$, regenerating $[\mathrm{R}]$ or control $[\mathrm{C}]$ ). Three plots were sampled at each site/zone/condition combination. Values are the mean and $(1 \mathrm{SE})$. Note that some elements were below detection limits $(<\mathrm{DL})$.

\begin{tabular}{|c|c|c|c|c|c|c|c|c|c|c|c|c|c|c|}
\hline$\underline{\text { Site }}$ & Zone & Condition & $n$ & $\underline{\mathrm{Al}}$ & $\mathrm{Ca}$ & $\mathrm{Cu}$ & $\mathrm{Fe}$ & $\mathrm{K}$ & $\mathrm{Mg}$ & $\mathrm{Mn}$ & $\mathrm{Na}$ & $\mathrm{P}$ & $\mathrm{S}$ & $\mathrm{Zn}$ \\
\hline $1-18$ & S & $\mathrm{H}$ & 48 & $\begin{array}{c}0.33 \\
(0.04)\end{array}$ & $\begin{array}{l}892.6 \\
(63.8)\end{array}$ & $<\mathrm{DL}$ & $\begin{array}{c}0.22 \\
(0.07)\end{array}$ & $\begin{array}{l}702.0 \\
(52.6)\end{array}$ & $\begin{array}{l}1314 \\
(100)\end{array}$ & $\begin{array}{c}3.53 \\
(0.54)\end{array}$ & $\begin{array}{l}3963 \\
(394)\end{array}$ & $\begin{array}{c}3.98 \\
(0.49)\end{array}$ & $\begin{array}{l}533.1 \\
(72.6)\end{array}$ & $\begin{array}{c}3.98 \\
(0.47)\end{array}$ \\
\hline $1-18$ & $\mathrm{~T}$ & $\mathrm{D}$ & 48 & $\begin{array}{c}0.30 \\
(0.04)\end{array}$ & $\begin{array}{l}899.2 \\
(65.9)\end{array}$ & $<\mathrm{DL}$ & $\begin{array}{c}0.11 \\
(0.05)\end{array}$ & $\begin{array}{l}719.4 \\
(47.9)\end{array}$ & $\begin{array}{l}1293 \\
(103)\end{array}$ & $\begin{array}{c}4.56 \\
(0.92)\end{array}$ & $\begin{array}{l}3722 \\
(358)\end{array}$ & $\begin{array}{c}3.68 \\
(0.56)\end{array}$ & $\begin{array}{l}512.9 \\
(66.4)\end{array}$ & $\begin{array}{c}3.80 \\
(0.68)\end{array}$ \\
\hline $1-18$ & I & $\mathrm{D}$ & 54 & $\begin{array}{c}0.44 \\
(0.07)\end{array}$ & $\begin{array}{l}1083.1 \\
(127.1)\end{array}$ & $<\mathrm{DL}$ & $\begin{array}{c}0.33 \\
(0.14)\end{array}$ & $\begin{array}{l}717.6 \\
(52.5)\end{array}$ & $\begin{array}{l}1433 \\
(131)\end{array}$ & $\begin{array}{c}5.43 \\
(0.91)\end{array}$ & $\begin{array}{c}4449 \\
(509)\end{array}$ & $\begin{array}{c}4.27 \\
(0.63)\end{array}$ & $\begin{array}{c}637.1 \\
(103.1)\end{array}$ & $\begin{array}{c}3.62 \\
(0.36)\end{array}$ \\
\hline $15-16$ & $S$ & $\mathrm{D}$ & 6 & $\begin{array}{c}0.54 \\
(0.24)\end{array}$ & $\begin{array}{l}719.0 \\
(92.5)\end{array}$ & $<\mathrm{DL}$ & $\begin{array}{c}0.15 \\
(0.09)\end{array}$ & $\begin{array}{l}835.9 \\
(98.4)\end{array}$ & $\begin{array}{l}1434 \\
(162)\end{array}$ & $\begin{array}{c}5.70 \\
(1.50)\end{array}$ & $\begin{array}{l}4706 \\
(984)\end{array}$ & $\begin{array}{c}4.26 \\
(0.47)\end{array}$ & $\begin{array}{c}912.8 \\
(274.8)\end{array}$ & $\begin{array}{c}3.45 \\
(0.92)\end{array}$ \\
\hline $19-21$ & $S$ & $\mathrm{C}$ & 9 & $\begin{array}{c}0.70 \\
(0.17)\end{array}$ & $\begin{array}{c}2035.8 \\
(336.5)\end{array}$ & $<\mathrm{DL}$ & $\begin{array}{c}0.46 \\
(0.04)\end{array}$ & $\begin{array}{r}1245.6 \\
(53.0)\end{array}$ & $\begin{array}{l}2614 \\
(122)\end{array}$ & $\begin{array}{c}6.97 \\
(1.12)\end{array}$ & $\begin{array}{l}9485 \\
(633)\end{array}$ & $\begin{array}{c}6.92 \\
(0.77)\end{array}$ & $\begin{array}{c}1623.2 \\
(127.6)\end{array}$ & $\begin{array}{c}6.53 \\
(1.33)\end{array}$ \\
\hline $19-21$ & I & $\mathrm{C}$ & 9 & $\begin{array}{c}1.01 \\
(0.36)\end{array}$ & $\begin{array}{c}2239.4 \\
(489.5)\end{array}$ & $<\mathrm{DL}$ & $<\mathrm{DL}$ & $\begin{array}{l}1594.0 \\
(136.8)\end{array}$ & $\begin{array}{l}3019 \\
(483)\end{array}$ & $\begin{array}{c}4.82 \\
(0.91)\end{array}$ & $\begin{array}{l}10267 \\
(2265)\end{array}$ & $\begin{array}{c}9.28 \\
(1.50)\end{array}$ & $\begin{array}{l}1536.5 \\
(258.5)\end{array}$ & $\begin{array}{c}8.31 \\
(1.62)\end{array}$ \\
\hline $4-6$ & I & $\mathrm{R}$ & 9 & $\begin{array}{c}0.21 \\
(0.04)\end{array}$ & $\begin{array}{l}624.2 \\
(94.1)\end{array}$ & $<\mathrm{DL}$ & $<\mathrm{DL}$ & $\begin{array}{l}502.2 \\
(30.8)\end{array}$ & $\begin{array}{l}851 \\
(59)\end{array}$ & $\begin{array}{c}2.25 \\
(0.91)\end{array}$ & $\begin{array}{l}2334 \\
(217)\end{array}$ & $\begin{array}{c}1.50 \\
(0.20)\end{array}$ & $\begin{array}{l}387.5 \\
(55.2)\end{array}$ & $\begin{array}{c}2.87 \\
(0.47)\end{array}$ \\
\hline
\end{tabular}


Table 13. Acid-extractable soil elemental concentrations ( $\mathrm{mg} / \mathrm{kg}$ ) measured in April 2001 at dieback and reference marshes dominated by Spartina spp. Values are given by site (1-21), zone (shoreline [S], transition [T], or interior [I]), and vegetative condition (healthy $[\mathrm{H}]$, dieback $[\mathrm{D}]$, regenerating $[\mathrm{R}]$ or control $[\mathrm{C}])$. Three plots were sampled at each site/zone/condition combination. Values are the mean and (1 SE).

\begin{tabular}{|c|c|c|c|c|c|c|c|c|c|c|c|c|c|c|}
\hline Site & Zone & Condition & $\mathrm{n}$ & $\mathrm{Al}$ & $\mathrm{Ca}$ & $\mathrm{Cu}$ & $\mathrm{Fe}$ & $\mathrm{K}$ & $\mathrm{Mg}$ & $\mathrm{Mn}$ & $\mathrm{Na}$ & $\mathrm{P}$ & $S$ & $\mathrm{Zn}$ \\
\hline $1-18$ & $S$ & $\mathrm{H}$ & 48 & $\begin{array}{l}19.70 \\
(4.82)\end{array}$ & $\begin{array}{r}1205 \\
(99)\end{array}$ & $\begin{array}{c}0.25 \\
(0.03)\end{array}$ & $\begin{array}{c}8.06 \\
(3.13)\end{array}$ & $\begin{array}{r}1328 \\
(91)\end{array}$ & $\begin{array}{c}2577 \\
(197)\end{array}$ & $\begin{array}{c}10.28 \\
(1.43)\end{array}$ & $\begin{array}{c}23219 \\
(1573)\end{array}$ & $\begin{array}{c}1.17 \\
(0.18)\end{array}$ & $\begin{array}{l}6558 \\
(475)\end{array}$ & $\begin{array}{c}7.24 \\
(0.81)\end{array}$ \\
\hline $1-18$ & $\mathrm{~T}$ & $\mathrm{D}$ & 48 & $\begin{array}{l}12.33 \\
(4.33)\end{array}$ & $\begin{array}{l}1184 \\
(114)\end{array}$ & $\begin{array}{c}0.22 \\
(0.03)\end{array}$ & $\begin{array}{l}7.24 \\
(3.23)\end{array}$ & $\begin{array}{c}1394 \\
(99)\end{array}$ & $\begin{array}{l}2625 \\
(227)\end{array}$ & $\begin{array}{l}11.62 \\
(2.00)\end{array}$ & $\begin{array}{l}23921 \\
(1849)\end{array}$ & $\begin{array}{c}2.27 \\
(0.91)\end{array}$ & $\begin{array}{l}6265 \\
(484)\end{array}$ & $\begin{array}{c}6.95 \\
(0.95)\end{array}$ \\
\hline $1-18$ & I & $\mathrm{D}$ & 54 & $\begin{array}{l}22.82 \\
(6.63)\end{array}$ & $\begin{array}{l}1417 \\
(172)\end{array}$ & $\begin{array}{c}0.33 \\
(0.07)\end{array}$ & $\begin{array}{l}12.23 \\
(4.32)\end{array}$ & $\begin{array}{l}1525 \\
(139)\end{array}$ & $\begin{array}{l}3165 \\
(371)\end{array}$ & $\begin{array}{l}14.29 \\
(2.75)\end{array}$ & $\begin{array}{l}27849 \\
(2783)\end{array}$ & $\begin{array}{c}1.17 \\
(0.20)\end{array}$ & $\begin{array}{l}7265 \\
(784)\end{array}$ & $\begin{array}{c}9.12 \\
(1.18)\end{array}$ \\
\hline $15-16$ & S & $\mathrm{D}$ & 6 & $\begin{array}{c}79.82 \\
(39.64)\end{array}$ & $\begin{array}{l}996 \\
(69)\end{array}$ & $\begin{array}{c}0.45 \\
(0.20)\end{array}$ & $\begin{array}{c}30.23 \\
(17.60)\end{array}$ & $\begin{array}{c}1313 \\
(67)\end{array}$ & $\begin{array}{l}2325 \\
(153)\end{array}$ & $\begin{array}{l}14.53 \\
(3.83)\end{array}$ & $\begin{array}{l}21556 \\
(906)\end{array}$ & $\begin{array}{c}0.17 \\
(0.13)\end{array}$ & $\begin{array}{l}6310 \\
(597)\end{array}$ & $\begin{array}{c}8.07 \\
(2.31)\end{array}$ \\
\hline $19-21$ & S & $\mathrm{C}$ & 9 & $\begin{array}{c}4.50 \\
(1.29)\end{array}$ & $\begin{array}{l}1779 \\
(221)\end{array}$ & $\begin{array}{c}0.28 \\
(0.05)\end{array}$ & $\begin{array}{c}0.03 \\
(0.03)\end{array}$ & $\begin{array}{l}1859 \\
(147)\end{array}$ & $\begin{array}{l}3681 \\
(362)\end{array}$ & $\begin{array}{l}21.18 \\
(4.03)\end{array}$ & $\begin{array}{c}33149 \\
(2771)\end{array}$ & $\begin{array}{c}3.19 \\
(0.48)\end{array}$ & $\begin{array}{c}9902 \\
(659)\end{array}$ & $\begin{array}{c}9.24 \\
(2.14)\end{array}$ \\
\hline $19-21$ & I & $\mathrm{C}$ & 9 & $\begin{array}{c}4.34 \\
(0.62)\end{array}$ & $\begin{array}{l}3267 \\
(889)\end{array}$ & $\begin{array}{c}0.58 \\
(0.20)\end{array}$ & $\begin{array}{c}0.02 \\
(0.02)\end{array}$ & $\begin{array}{l}2605 \\
(269)\end{array}$ & $\begin{array}{l}5812 \\
(773)\end{array}$ & $\begin{array}{l}17.68 \\
(6.04)\end{array}$ & $\begin{array}{l}51633 \\
(6579)\end{array}$ & $\begin{array}{c}6.56 \\
(2.36)\end{array}$ & $\begin{array}{l}12455 \\
(1597)\end{array}$ & $\begin{array}{l}14.98 \\
(2.84)\end{array}$ \\
\hline $4-6$ & I & $\mathrm{R}$ & 9 & $\begin{array}{c}2.23 \\
(0.82)\end{array}$ & $\begin{array}{l}765 \\
(88)\end{array}$ & $\begin{array}{c}0.23 \\
(0.04)\end{array}$ & $\begin{array}{c}0.45 \\
(0.21)\end{array}$ & $\begin{array}{c}1077 \\
(93)\end{array}$ & $\begin{array}{l}1823 \\
(158)\end{array}$ & $\begin{array}{c}6.66 \\
(2.16)\end{array}$ & $\begin{array}{l}18056 \\
(1241)\end{array}$ & $\begin{array}{c}0.78 \\
(0.22)\end{array}$ & $\begin{array}{c}4492 \\
(460)\end{array}$ & $\begin{array}{c}5.04 \\
(1.29)\end{array}$ \\
\hline
\end{tabular}


Table 14. Factor analysis of soil elemental concentrations measured at all sites (1-21) and zones (healthy shoreline [HS], transition [T], dieback interior [DI], dieback shoreline [DS], regenerating [R], control shoreline [CS], control interior [CI]) in April 2001.

Principal component analysis was used to reduce the number of variables and multicollinearity. The rotated factor pattern is given for water-, ammonium acetate-, and acid-extracted elements. Individual factor scores were subjected to ANOVA with site and zone (nested within site) as grouping factors. F-ratios for main effects and $1 \mathrm{DF}$ contrasts are given below the factor patterns; significance indicated by $*(\mathrm{p} \leq 0.05), * *(\mathrm{p} \leq 0.01), * * *(\mathrm{p} \leq 0.001), * * * *(\mathrm{p} \leq 0.0001)$, or ns (not significant).

\begin{tabular}{|c|c|c|c|c|c|c|}
\hline \multirow[t]{2}{*}{ Extraction: } & \multicolumn{2}{|c|}{ Water } & \multicolumn{2}{|c|}{ Ammonium Acetate } & \multicolumn{2}{|c|}{ Acid } \\
\hline & Factor 1 & Factor 2 & Factor 1 & $\overline{\text { Factor } 2}$ & Factor 1 & Factor 2 \\
\hline $\mathrm{Al}$ & 0.41 & 0.70 & 0.38 & 0.57 & -0.12 & 0.87 \\
\hline $\mathrm{Ca}$ & 0.96 & 0.07 & 0.87 & 0.10 & 0.94 & 0.06 \\
\hline $\mathrm{Cu}$ & 0.18 & 0.51 & - & - & 0.20 & 0.80 \\
\hline $\mathrm{Fe}$ & -0.10 & 0.68 & - & - & -0.13 & 0.82 \\
\hline $\mathrm{K}$ & 0.97 & 0.00 & 0.81 & 0.37 & 0.98 & 0.00 \\
\hline $\mathrm{Mg}$ & 0.98 & 0.09 & 0.91 & 0.27 & 0.98 & 0.06 \\
\hline $\mathrm{Mn}$ & 0.63 & 0.07 & 0.10 & 0.84 & 0.52 & 0.49 \\
\hline $\mathrm{Na}$ & 0.96 & 0.05 & 0.86 & 0.38 & 0.96 & 0.00 \\
\hline $\mathrm{P}$ & -0.05 & 0.57 & 0.82 & 0.17 & 0.15 & 0.34 \\
\hline $\mathrm{S}$ & 0.98 & 0.06 & 0.61 & 0.62 & 0.98 & 0.11 \\
\hline $\mathrm{Zn}$ & 0.68 & 0.34 & 0.15 & 0.65 & 0.56 & 0.38 \\
\hline Cumulative percent & d 53 & 68 & 46 & 71 & 49 & 72 \\
\hline \multicolumn{7}{|l|}{ ANOVA Source: } \\
\hline Site & $22.31 * * * *$ & $3.10 * * * *$ & $27.04 * * * *$ & $9.55 * * * *$ & $30.77 * * * *$ & $6.65 * * * *$ \\
\hline Zone (site) & $1.01 \mathrm{~ns}$ & $1.84 * *$ & $1.89 * *$ & $2.05 * *$ & $1.94 * *$ & $3.06 * * * *$ \\
\hline \multicolumn{7}{|l|}{ Contrasts: } \\
\hline$\overline{\text { HS vs. DI }}$ & - & $1.82 \mathrm{~ns}$ & $0.39 \mathrm{~ns}$ & $2.29 \mathrm{~ns}$ & $5.23 * *$ & $1.50 \mathrm{~ns}$ \\
\hline HS vs. T & - & $4.71 *$ & $0.56 \mathrm{~ns}$ & $0.38 \mathrm{~ns}$ & $0.09 \mathrm{~ns}$ & $4.61 *$ \\
\hline DI vs. CI & - & $5.38 *$ & $104.5 * * * *$ & $5.03 *$ & $74.73 * * * *$ & $4.16^{*}$ \\
\hline Dieback vs. Control & $29.84 * * * *$ & $4.95 *$ & $165.4 * * * *$ & $16.14 * * * *$ & $113.4 * * * *$ & $2.83 *$ \\
\hline
\end{tabular}




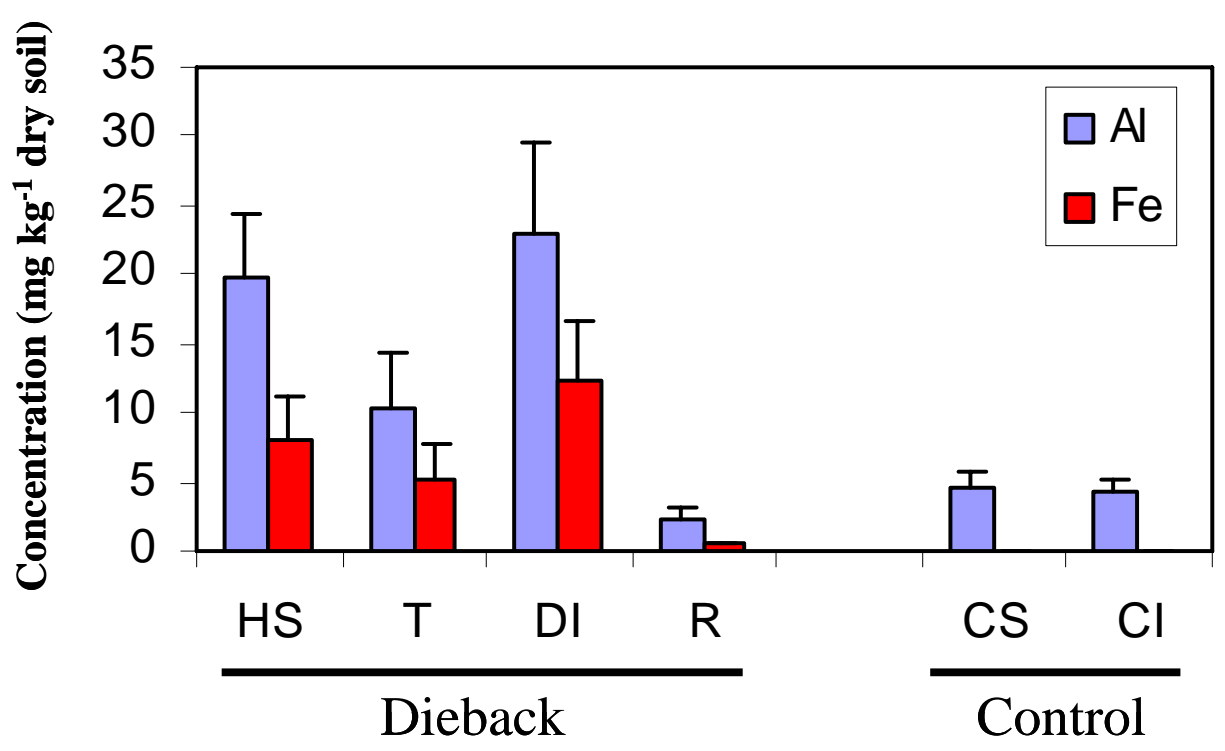

Figure 16. Acid-extractable $\mathrm{Al}$ and Fe concentrations in different vegetation zones in April 2001. Marsh zones dominated by Spartina spp. are healthy shoreline (HS), transition (T), dieback interior (DI), regenerating (R), control shoreline (CS), and control interior (CI). Values are the mean $\pm 1 \mathrm{SE}(\mathrm{n}=47-54, \mathrm{HS}, \mathrm{T}, \mathrm{DI} ; \mathrm{n}=8-9$, R, CS, CI). 
Table 15. Results of ANOVA for soil pyrite (August 2000), and acid extractable Al and Fe concentrations (April 2001) in zones (healthy shoreline [HS], transition [T], dieback interior [DI], dieback shoreline [DS], control shoreline [CS], control interior [CI], regenerating [R], and Juncus roemerianus [needlegrass rush]) where site and zone (nested within site) were the grouping factors. Values are the F-ratio, and significance is indicated by $*(\mathrm{p} \leq 0.05), * *(\mathrm{p} \leq 0.01), * * *(\mathrm{p} \leq 0.001), * * * *(\mathrm{p} \leq 0.0001)$, or ns (not significant).

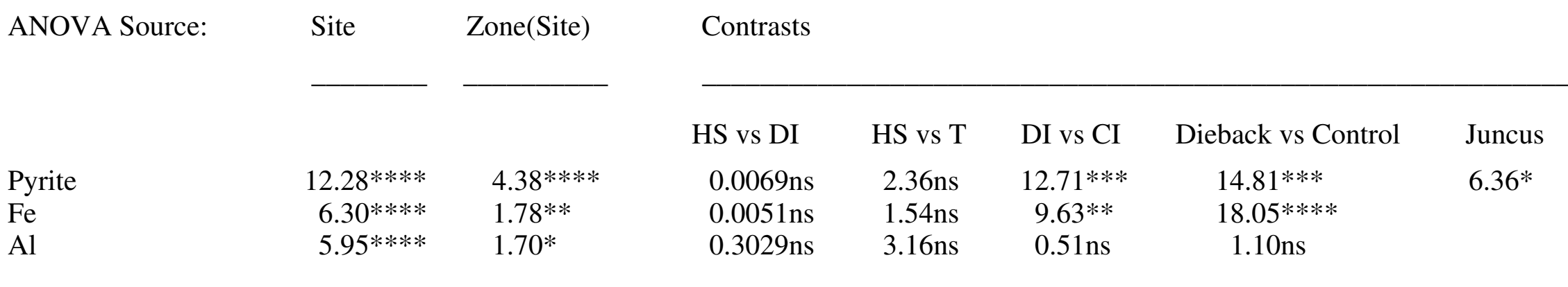




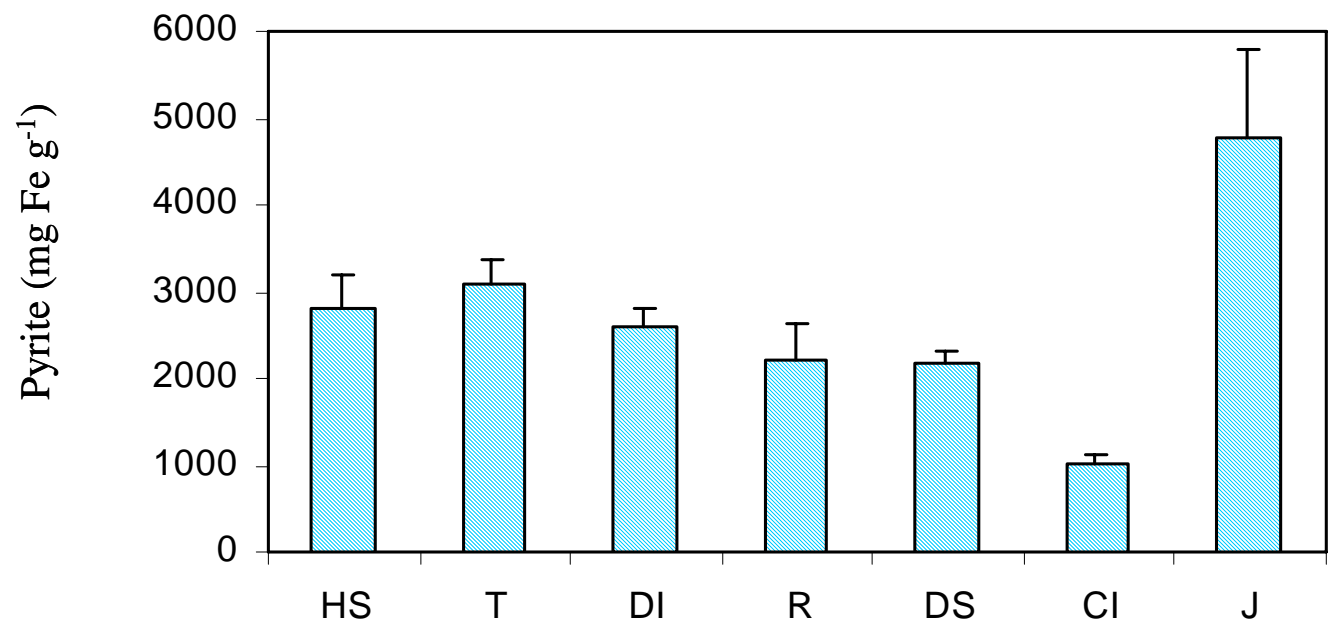

Figure 17. Soil pyrite concentrations in different vegetation zones in August 2000. Marsh zones dominated by Spartina spp. are healthy shoreline (HS), transition (T), dieback interior (DI), regenerating (R), dieback shoreline (DS), and control interior (CI). Two stands of healthy Juncus roemerianus (J) were sampled in the dieback interior at site16. Values are the mean \pm 1 SE $(n=46-51$, HS, T, DI; $n=6, R, D S, C I ; n=2, J)$. 


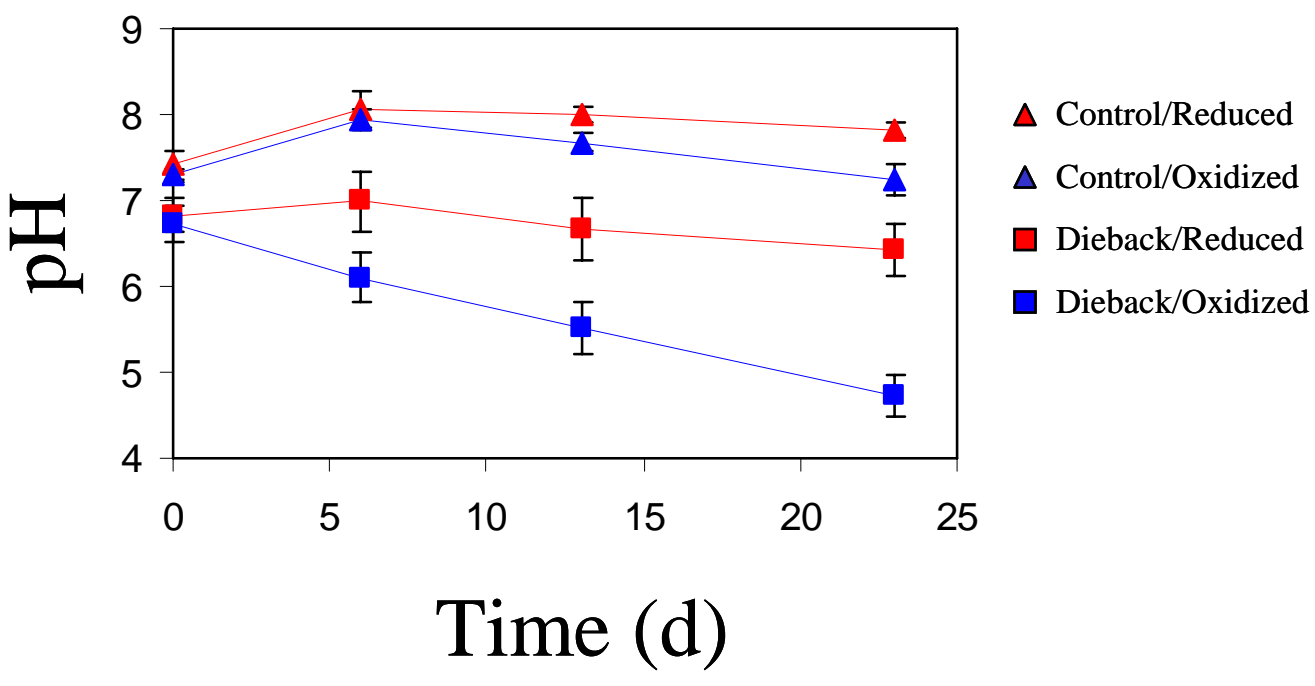

Figure 18. Acidification potential of soils from dieback and control marshes. Soil was collected in August 2000 and incubated under reduced (purged with $\mathrm{N}_{2}$ gas) or oxidized (purged with air) treatments. 
Table 16. Elemental concentrations ( $\mu \mathrm{g} / \mathrm{g}$ ) measured in Spartina alterniflora (smooth cordgrass) leaves in August 2000 at dieback and reference marshes. Values are given by site (2-21); zone (shoreline [S], transition [T], or interior [I]); and vegetative condition (healthy $[\mathrm{H}]$, dieback [D], regenerating [R], or control $[\mathrm{C}]$ ). Three plots were sampled at each site/zone/condition combination.

Values are the mean and (1 SE).

\begin{tabular}{|c|c|c|c|c|c|c|c|c|c|c|c|c|c|c|c|c|c|}
\hline \multicolumn{4}{|c|}{ Site Zone Condition $\mathrm{n}$} & $\underline{\mathrm{Al}}$ & $\mathrm{Ca}$ & $\mathrm{Cu}$ & $\mathrm{Fe}$ & $\mathrm{K}$ & $\mathrm{Mg}$ & $\mathrm{Mn}$ & Mo & $\mathrm{Na}$ & $\mathrm{Ni}$ & $\mathrm{P}$ & $\mathrm{Pb}$ & $S$ & $\mathrm{Zn}$ \\
\hline $2-18$ & S & $\mathrm{H}$ & 51 & $\begin{array}{c}91.71 \\
(13.45)\end{array}$ & $\begin{array}{l}3007 \\
(257)\end{array}$ & $\begin{array}{c}4.32 \\
(0.97)\end{array}$ & $\begin{array}{c}204.86 \\
(27.34)\end{array}$ & $\begin{array}{r}10534 \\
(449)\end{array}$ & $\begin{array}{l}2893 \\
(212)\end{array}$ & $\begin{array}{c}55.95 \\
(10.21)\end{array}$ & $\begin{array}{c}1.49 \\
(0.24)\end{array}$ & $\begin{array}{r}18492 \\
(416)\end{array}$ & $\begin{array}{r}41.39 \\
(21.25\end{array}$ & $\begin{array}{r}1164 \\
(58)\end{array}$ & $\begin{array}{c}1.44 \\
(0.13)\end{array}$ & $\begin{array}{l}4634 \\
(527)\end{array}$ & $\begin{array}{l}17.77 \\
(1.57)\end{array}$ \\
\hline $2-18$ & $\mathrm{~T}$ & $\mathrm{D}$ & 48 & $\begin{array}{l}71.11 \\
(5.71)\end{array}$ & $\begin{array}{l}2871 \\
(189)\end{array}$ & $\begin{array}{c}3.80 \\
(0.79)\end{array}$ & $\begin{array}{l}179.61 \\
(25.44)\end{array}$ & $\begin{array}{r}11285 \\
(641)\end{array}$ & $\begin{array}{l}2809 \\
(223)\end{array}$ & $\begin{array}{l}35.16 \\
(2.96)\end{array}$ & $\begin{array}{c}1.22 \\
(0.26)\end{array}$ & $\begin{array}{r}20257 \\
(734)\end{array}$ & $\begin{array}{r}54.91 \\
(34.88\end{array}$ & $\begin{array}{r}1057 \\
(58)\end{array}$ & $\begin{array}{c}1.21 \\
(0.04)\end{array}$ & $\begin{array}{l}6454 \\
(798)\end{array}$ & $\begin{array}{l}18.62 \\
(2.17)\end{array}$ \\
\hline $2-18$ & I & $\mathrm{D}$ & 48 & $\begin{array}{l}164.63 \\
(20.19)\end{array}$ & $\begin{array}{l}2862 \\
(175)\end{array}$ & $\begin{array}{c}3.32 \\
(0.67)\end{array}$ & $\begin{array}{c}276.75 \\
(29.19)\end{array}$ & $\begin{array}{l}9957 \\
(774)\end{array}$ & $\begin{array}{l}2912 \\
(203)\end{array}$ & $\begin{array}{l}43.48 \\
(4.83)\end{array}$ & $\begin{array}{c}1.02 \\
(0.17)\end{array}$ & $\begin{array}{r}19890 \\
(960)\end{array}$ & $\begin{array}{r}15.39 \\
(9.91\end{array}$ & $\begin{array}{l}942 \\
(47)\end{array}$ & $\begin{array}{c}1.72 \\
(0.23)\end{array}$ & $\begin{array}{l}5045 \\
(580)\end{array}$ & $\begin{array}{l}17.78 \\
(1.66)\end{array}$ \\
\hline $15-16$ & $\mathrm{~S}$ & $\mathrm{D}$ & 6 & $\begin{array}{l}185.34 \\
(26.74)\end{array}$ & $\begin{array}{l}2505 \\
(114)\end{array}$ & $\begin{array}{c}2.04 \\
(0.33)\end{array}$ & $\begin{array}{l}314.71 \\
(98.19)\end{array}$ & $\begin{array}{r}12055 \\
(139)\end{array}$ & $\begin{array}{l}2584 \\
(452)\end{array}$ & $\begin{array}{l}14.53 \\
(2.18)\end{array}$ & $\begin{array}{c}0.82 \\
(0.14)\end{array}$ & $\begin{array}{c}9728 \\
(1677)\end{array}$ & $\begin{array}{r}2.35 \\
(1.16\end{array}$ & $\begin{array}{r}1230 \\
(38)\end{array}$ & $\begin{array}{c}3.96 \\
(1.31)\end{array}$ & & $\begin{array}{l}10.95 \\
(1.11)\end{array}$ \\
\hline $19-21$ & I & $\mathrm{C}$ & 9 & $\begin{array}{c}146.25 \\
(44.77)\end{array}$ & $\begin{array}{l}2137 \\
(367)\end{array}$ & $\begin{array}{c}1.17 \\
(0.27)\end{array}$ & $\begin{array}{c}127.93 \\
(30.22)\end{array}$ & $\begin{array}{l}9485 \\
(753)\end{array}$ & $\begin{array}{l}3034 \\
(608)\end{array}$ & $\begin{array}{c}35.42 \\
(14.82)\end{array}$ & $\begin{array}{c}0.55 \\
(0.05)\end{array}$ & $\begin{array}{c}16493 \\
(480)\end{array}$ & $\begin{array}{r}0.55 \\
(0.13\end{array}$ & $\begin{array}{l}805 \\
(35)\end{array}$ & $\begin{array}{c}1.28 \\
(0.12)\end{array}$ & 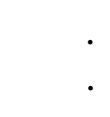 & $\begin{array}{c}9.05 \\
(1.57)\end{array}$ \\
\hline 6 & I & $\mathrm{R}$ & 3 & $\begin{array}{r}111.60 \\
\quad(5.90) \\
\end{array}$ & $\begin{array}{l}2715 \\
(293) \\
\end{array}$ & $\begin{array}{r}4.33 \\
(0.78) \\
\end{array}$ & $\begin{array}{r}155.79 \\
(2.56) \\
\end{array}$ & $\begin{array}{r}13411 \\
(269) \\
\end{array}$ & $\begin{array}{l}1705 \\
(256) \\
\end{array}$ & $\begin{array}{l}68.03 \\
(4.16) \\
\end{array}$ & $\begin{array}{r}1.24 \\
(0.09) \\
\end{array}$ & $\begin{array}{l}16855 \\
(1228) \\
\end{array}$ & . & $\begin{array}{r}1649 \\
(54) \\
\end{array}$ & $\begin{array}{r}1.52 \\
(0.31) \\
\end{array}$ & $\begin{array}{l}2815 \\
(216) \\
\end{array}$ & $\begin{array}{l}24.34 \\
(5.99) \\
\end{array}$ \\
\hline
\end{tabular}


Table 17. Elemental concentrations ( $\mu \mathrm{g} / \mathrm{g}$ ) measured in Spartina alterniflora (smooth cordgrass) leaves in April 2001 at dieback and reference marshes. Values are given by site (2-21); zone (shoreline [S], transition [T], or interior [I]); and vegetative condition (healthy $[\mathrm{H}]$, dieback $[\mathrm{D}]$, regenerating $[\mathrm{R}]$, or control $[\mathrm{C}]$ ). Three plots were sampled at each site/zone/condition combination. Values are the mean and (1 SE).

\begin{tabular}{|c|c|c|c|c|c|c|c|c|c|c|c|c|c|c|c|c|c|}
\hline$\underline{\text { Site }}$ & Zone & Condit & $\mathrm{n}$ & $\underline{\mathrm{Al}}$ & $\mathrm{Ca}$ & $\mathrm{Cu}$ & $\mathrm{Fe}$ & $\mathrm{K}$ & $\mathrm{Mg}$ & $\mathrm{Mn}$ & Mo & $\mathrm{Na}$ & $\mathrm{Ni}$ & $\mathrm{P}$ & $\mathrm{Pb}$ & $S$ & $\underline{\mathrm{Zn}}$ \\
\hline $2-18$ & $\mathrm{~S}$ & $\mathrm{H}$ & 51 & $\begin{array}{l}97.27 \\
(4.58)\end{array}$ & $\begin{array}{l}2505 \\
(98)\end{array}$ & $\begin{array}{c}3.39 \\
(0.12)\end{array}$ & $\begin{array}{r}127.50 \\
(7.96)\end{array}$ & $\begin{array}{r}12665 \\
(310)\end{array}$ & $\begin{array}{c}3029 \\
(95)\end{array}$ & $\begin{array}{l}60.50 \\
(4.37)\end{array}$ & $\begin{array}{c}0.63 \\
(0.05)\end{array}$ & $\begin{array}{r}17822 \\
(586)\end{array}$ & $\begin{array}{c}2.15 \\
(0.21)\end{array}$ & $\begin{array}{r}1450 \\
(43)\end{array}$ & $\begin{array}{c}0.32 \\
(0.04)\end{array}$ & $\begin{array}{r}2067 \\
(82)\end{array}$ & $\begin{array}{l}12.74 \\
(0.68)\end{array}$ \\
\hline $2-18$ & $\mathrm{~T}$ & D & 48 & $\begin{array}{r}119.48 \\
(7.63)\end{array}$ & $\begin{array}{l}2529 \\
(85)\end{array}$ & $\begin{array}{c}3.35 \\
(0.17)\end{array}$ & $\begin{array}{c}194.53 \\
(19.10)\end{array}$ & $\begin{array}{c}12151 \\
(236)\end{array}$ & $\begin{array}{l}3080 \\
(114)\end{array}$ & $\begin{array}{l}73.87 \\
(5.89)\end{array}$ & $\begin{array}{c}0.45 \\
(0.05)\end{array}$ & $\begin{array}{r}16712 \\
(596)\end{array}$ & $\begin{array}{c}2.49 \\
(0.22)\end{array}$ & $\begin{array}{l}1299 \\
(34)\end{array}$ & $\begin{array}{c}0.44 \\
(0.06)\end{array}$ & $\begin{array}{l}2287 \\
(104)\end{array}$ & $\begin{array}{l}15.56 \\
(1.22)\end{array}$ \\
\hline $2-18$ & I & D & 52 & $\begin{array}{r}148.27 \\
(8.47)\end{array}$ & $\begin{array}{r}3317 \\
(91)\end{array}$ & $\begin{array}{c}4.12 \\
(0.23)\end{array}$ & $\begin{array}{l}217.88 \\
(15.84)\end{array}$ & $\begin{array}{r}12955 \\
(232)\end{array}$ & $\begin{array}{c}3655 \\
(108)\end{array}$ & $\begin{array}{l}84.17 \\
(6.67)\end{array}$ & $\begin{array}{c}0.52 \\
(0.06)\end{array}$ & $\begin{array}{c}18218 \\
(600)\end{array}$ & $\begin{array}{c}2.10 \\
(0.21)\end{array}$ & $\begin{array}{r}1502 \\
(56)\end{array}$ & $\begin{array}{c}0.38 \\
(0.04)\end{array}$ & $\begin{array}{c}2909 \\
(137)\end{array}$ & $\begin{array}{l}17.48 \\
(0.82)\end{array}$ \\
\hline $15-16$ & $\mathrm{~S}$ & D & 6 & $\begin{array}{l}143.30 \\
(21.04)\end{array}$ & $\begin{array}{l}2725 \\
(237)\end{array}$ & $\begin{array}{c}5.81 \\
(0.35)\end{array}$ & $\begin{array}{l}225.93 \\
(26.24)\end{array}$ & $\begin{array}{r}13684 \\
(837)\end{array}$ & $\begin{array}{c}2772 \\
(159)\end{array}$ & $\begin{array}{c}98.48 \\
(19.18)\end{array}$ & $\begin{array}{c}0.23 \\
(0.10)\end{array}$ & $\begin{array}{r}17381 \\
(951)\end{array}$ & $\begin{array}{c}1.87 \\
(0.59)\end{array}$ & $\begin{array}{r}1655 \\
(74)\end{array}$ & $\begin{array}{c}0.34 \\
(0.07)\end{array}$ & $\begin{array}{l}2056 \\
(156)\end{array}$ & $\begin{array}{l}12.06 \\
(0.57)\end{array}$ \\
\hline $19-21$ & $\mathrm{~S}$ & $\mathrm{C}$ & 9 & $\begin{array}{l}46.36 \\
(2.46)\end{array}$ & $\begin{array}{l}2769 \\
(389)\end{array}$ & $\begin{array}{c}3.94 \\
(0.42)\end{array}$ & $\begin{array}{c}98.84 \\
(10.47)\end{array}$ & $\begin{array}{c}13883 \\
(720)\end{array}$ & $\begin{array}{c}3082 \\
(390)\end{array}$ & $\begin{array}{c}86.79 \\
(18.07)\end{array}$ & $\begin{array}{c}0.46 \\
(0.06)\end{array}$ & $\begin{array}{l}17166 \\
(1210)\end{array}$ & $\begin{array}{c}2.51 \\
(0.35)\end{array}$ & $\begin{array}{l}1232 \\
(118)\end{array}$ & $\begin{array}{c}0.21 \\
(0.02)\end{array}$ & $\begin{array}{l}1774 \\
(131)\end{array}$ & $\begin{array}{l}14.29 \\
(0.72)\end{array}$ \\
\hline $19-21$ & I & $\mathrm{C}$ & 9 & $\begin{array}{l}38.90 \\
(1.58)\end{array}$ & $\begin{array}{l}2289 \\
(183)\end{array}$ & $\begin{array}{c}4.38 \\
(0.56)\end{array}$ & $\begin{array}{c}98.48 \\
(30.61)\end{array}$ & $\begin{array}{r}15951 \\
(622)\end{array}$ & $\begin{array}{c}2734 \\
(186)\end{array}$ & $\begin{array}{l}43.28 \\
(6.26)\end{array}$ & $\begin{array}{c}0.72 \\
(0.07)\end{array}$ & $\begin{array}{l}20368 \\
(1754)\end{array}$ & $\begin{array}{c}2.36 \\
(0.17)\end{array}$ & $\begin{array}{r}1121 \\
(52)\end{array}$ & $\begin{array}{c}0.19 \\
(0.01)\end{array}$ & $\begin{array}{l}2580 \\
(487)\end{array}$ & $\begin{array}{l}16.54 \\
(1.05)\end{array}$ \\
\hline 6 & I & $\mathrm{R}$ & 3 & $\begin{array}{r}137.42 \\
(4.07)\end{array}$ & $\begin{array}{l}2763 \\
(162)\end{array}$ & $\begin{array}{c}3.71 \\
(0.09)\end{array}$ & $\begin{array}{l}196.42 \\
(40.03)\end{array}$ & $\begin{array}{r}11339 \\
(125)\end{array}$ & $\begin{array}{c}3682 \\
(100)\end{array}$ & $\begin{array}{r}133.76 \\
(3.98)\end{array}$ & $\begin{array}{c}0.65 \\
(0.11)\end{array}$ & $\begin{array}{l}14698 \\
(1057)\end{array}$ & $\begin{array}{c}1.42 \\
(0.41)\end{array}$ & $\begin{array}{r}1416 \\
(9)\end{array}$ & $\begin{array}{c}0.65 \\
(0.00)\end{array}$ & $\begin{array}{l}2116 \\
(123)\end{array}$ & $\begin{array}{l}15.55 \\
(0.40)\end{array}$ \\
\hline
\end{tabular}


Table 18. Elemental concentrations ( $\mu \mathrm{g} / \mathrm{g}$ ) measured in Spartina alterniflora (smooth cordgrass) (sites 2-21) and $S$. patens (marshhay cordgrass) (site 1) leaves in September 2001 at dieback and reference marshes. Values are given by site (1-21); zone (shoreline [S], transition [T], or interior [I]); and vegetative condition (healthy [H], dieback [D], regenerating [R], or control [C]). Three plots were sampled at each site/zone/condition combination. Values are the mean and (1 SE).

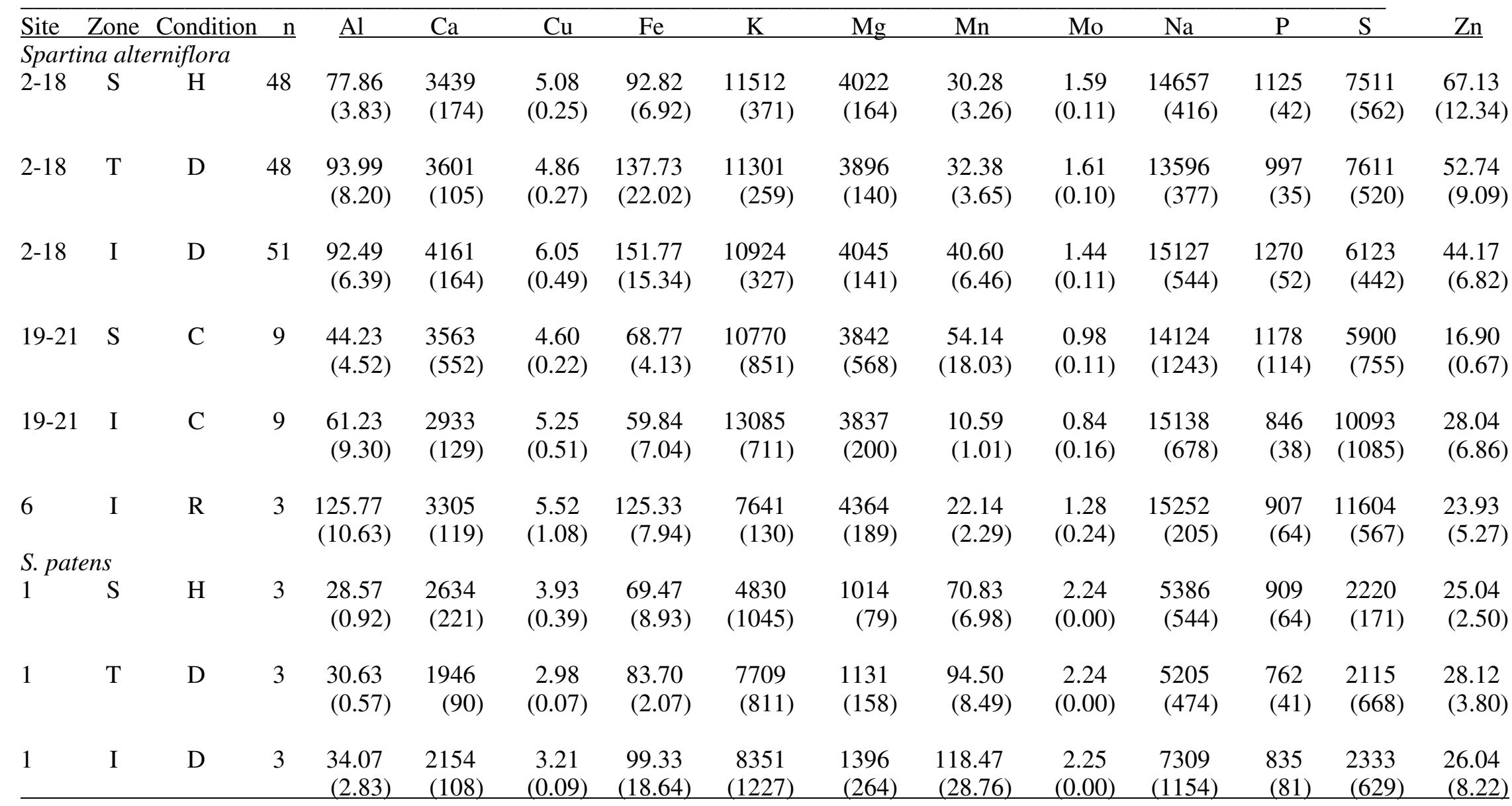


Table 19. Elemental concentrations ( $\mu \mathrm{g} / \mathrm{g}$ ) measured in Spartina patens (marshhay cordgrass) (site 1) and Juncus roemerianus (needlgrass rush) (site 16) leaves in August 2000 (A) and April 2001 (B). Values are the mean and (1 SE).

\begin{tabular}{|c|c|c|c|c|c|c|c|c|c|c|c|c|c|c|c|c|c|}
\hline \multirow{2}{*}{\multicolumn{3}{|c|}{$\begin{array}{l}\text { Site Zone Condition } \\
\text { A. August } 2000 \\
\text { Juncus roemerianus }\end{array}$}} & $\mathrm{n}$ & $\underline{\mathrm{Al}}$ & $\mathrm{Ca}$ & $\mathrm{Cu}$ & $\mathrm{Fe}$ & $\mathrm{K}$ & $\mathrm{Mg}$ & Mn & Mo & $\mathrm{Na}$ & $\mathrm{Ni}$ & $\mathrm{P}$ & $\mathrm{Pb}$ & $\mathrm{S}$ & $\mathrm{Zn}$ \\
\hline & & & & & & & & & & & & & & & & & \\
\hline 16 & I & $\mathrm{H}$ & 3 & $\begin{array}{c}517.14 \\
(81.21)\end{array}$ & $\begin{array}{l}2089 \\
(181)\end{array}$ & $\begin{array}{c}1.91 \\
(0.07)\end{array}$ & $\begin{array}{c}449.40 \\
(66.32)\end{array}$ & $\begin{array}{r}10374 \\
(565)\end{array}$ & $\begin{array}{l}3746 \\
(323)\end{array}$ & $\begin{array}{l}18.51 \\
(0.86)\end{array}$ & $\begin{array}{c}0.18 \\
(0.02)\end{array}$ & $\begin{array}{l}12918 \\
(1333)\end{array}$ & $\begin{array}{c}1.67 \\
(0.40)\end{array}$ & $\begin{array}{r}1363 \\
(36)\end{array}$ & $\begin{array}{c}1.59 \\
(0.06)\end{array}$ & & $\begin{array}{c}14.06 \\
(0.46)\end{array}$ \\
\hline \multicolumn{18}{|c|}{ Spartina patens } \\
\hline 1 & S & $\mathrm{H}$ & 3 & $\begin{array}{l}34.48 \\
(3.06)\end{array}$ & $\begin{array}{l}3292 \\
(167)\end{array}$ & $\begin{array}{c}3.11 \\
(0.22)\end{array}$ & $\begin{array}{r}109.62 \\
(5.45)\end{array}$ & $\begin{array}{l}13428 \\
(385)\end{array}$ & $\begin{array}{l}2815 \\
(140)\end{array}$ & $\begin{array}{c}517.36 \\
(37.77)\end{array}$ & $\begin{array}{c}0.74 \\
(0.11)\end{array}$ & $\begin{array}{l}5433 \\
(349)\end{array}$ & . & $\begin{array}{r}1206 \\
(73)\end{array}$ & $\begin{array}{c}1.71 \\
(0.29)\end{array}$ & $\begin{array}{l}3378 \\
(113\end{array}$ & $\begin{array}{l}11.25 \\
(0.77)\end{array}$ \\
\hline 1 & $\mathrm{~T}$ & $\mathrm{D}$ & 3 & $\begin{array}{c}41.91 \\
(4.54)\end{array}$ & $\begin{array}{l}2702 \\
(134)\end{array}$ & $\begin{array}{c}2.48 \\
(0.04)\end{array}$ & $\begin{array}{l}89.75 \\
(4.35)\end{array}$ & $\begin{array}{l}13213 \\
(280)\end{array}$ & $\begin{array}{l}2042 \\
(138)\end{array}$ & $\begin{array}{r}356.48 \\
(9.97)\end{array}$ & $\begin{array}{c}1.44 \\
(0.21)\end{array}$ & $\begin{array}{r}5384 \\
(83)\end{array}$ & . & $\begin{array}{r}1061 \\
(17)\end{array}$ & $\begin{array}{c}1.84 \\
(0.22)\end{array}$ & $\begin{array}{l}3665 \\
(206\end{array}$ & $\begin{array}{l}14.86 \\
(1.65)\end{array}$ \\
\hline 1 & I & $\mathrm{D}$ & 3 & $\begin{array}{c}34.32 \\
(5.64)\end{array}$ & $\begin{array}{r}2333 \\
(15)\end{array}$ & $\begin{array}{c}2.80 \\
(0.12)\end{array}$ & $\begin{array}{l}182.98 \\
(83.79)\end{array}$ & $\begin{array}{c}12941 \\
(893)\end{array}$ & $\begin{array}{r}2353 \\
(60)\end{array}$ & $\begin{array}{c}454.09 \\
(36.02)\end{array}$ & $\begin{array}{c}2.97 \\
(0.26)\end{array}$ & $\begin{array}{c}5649 \\
(529)\end{array}$ & . & $\begin{array}{l}1097 \\
(146)\end{array}$ & $\begin{array}{c}1.04 \\
(0.05)\end{array}$ & $\begin{array}{l}3504 \\
(217\end{array}$ & $\begin{array}{l}14.97 \\
(0.56)\end{array}$ \\
\hline \multicolumn{18}{|c|}{ B. April 2001} \\
\hline 16 & I & $\mathrm{H}$ & 3 & $\begin{array}{c}117.05 \\
(17.43)\end{array}$ & $\begin{array}{l}918 \\
(88)\end{array}$ & $\begin{array}{c}3.17 \\
(0.10)\end{array}$ & $\begin{array}{c}130.83 \\
(18.81)\end{array}$ & $\begin{array}{l}7937 \\
(118)\end{array}$ & $\begin{array}{l}1682 \\
(190)\end{array}$ & $\begin{array}{l}90.05 \\
(9.71)\end{array}$ & $\begin{array}{c}0.34 \\
(0.08)\end{array}$ & $\begin{array}{l}8010 \\
(932)\end{array}$ & $\begin{array}{c}1.17 \\
(0.13)\end{array}$ & $\begin{array}{l}735 \\
(14)\end{array}$ & $\begin{array}{c}0.21 \\
(0.03)\end{array}$ & $\begin{array}{r}1043 \\
(70)\end{array}$ & $\begin{array}{c}17.35 \\
(0.81)\end{array}$ \\
\hline $\begin{array}{l}\text { S. } p c \\
1\end{array}$ & $\begin{array}{r}\text { ens } \\
\text { S }\end{array}$ & $\mathrm{H}$ & 3 & $\begin{array}{l}65.82 \\
(2.37)\end{array}$ & $\begin{array}{l}1766 \\
(170)\end{array}$ & $\begin{array}{c}2.16 \\
(0.20)\end{array}$ & $\begin{array}{l}109.96 \\
(13.56)\end{array}$ & $\begin{array}{l}9014 \\
(545)\end{array}$ & $\begin{array}{r}1341 \\
(25)\end{array}$ & $\begin{array}{l}71.17 \\
(5.07)\end{array}$ & $\begin{array}{c}0.27 \\
(0.05)\end{array}$ & $\begin{array}{l}8258 \\
(336)\end{array}$ & $\begin{array}{c}1.93 \\
(0.09)\end{array}$ & $\begin{array}{l}1009 \\
(161)\end{array}$ & $\begin{array}{c}0.67 \\
(0.02)\end{array}$ & $\begin{array}{r}1438 \\
(89)\end{array}$ & $\begin{array}{c}15.02 \\
(5.00)\end{array}$ \\
\hline 1 & I & $\mathrm{D}$ & 3 & $\begin{array}{c}751.08 \\
(39.92) \\
\end{array}$ & $\begin{array}{l}1667 \\
(215)\end{array}$ & $\begin{array}{c}2.69 \\
(0.10) \\
\end{array}$ & $\begin{array}{l}3237.04 \\
(259.65)\end{array}$ & $\begin{array}{r}1081 \\
(52) \\
\end{array}$ & $\begin{array}{l}2107 \\
(333)\end{array}$ & $\begin{array}{l}198.98 \\
(28.88)\end{array}$ & $\begin{array}{c}0.02 \\
(0.00)\end{array}$ & $\begin{array}{c}3663 \\
(940) \\
\end{array}$ & $\begin{array}{c}4.55 \\
(1.57)\end{array}$ & $\begin{array}{c}458 \\
(14)\end{array}$ & $\begin{array}{c}1.92 \\
(0.11)\end{array}$ & $\begin{array}{l}1814 \\
(283) \\
\end{array}$ & $\begin{array}{r}33.75 \\
(12.19) \\
\end{array}$ \\
\hline
\end{tabular}


When factor scores were subjected to ANOVA, significant differences among sites and across zones were found (table 20). This analysis indicated that there were spatial differences in tissue concentrations of correlated cations and metals. In particular, the factor patterns indicated differences in tissue elemental composition that might reflect spatial variation in uptake of potentially toxic elements that might be released upon acidification of soils (Fe, Al, Mn) or associated with elevated salinity (Na). Leaf concentrations of these elements were thus examined individually (as ratios of $\mathrm{K}$ ) to compare relative uptake in dieback and control marshes on different sampling dates. Leaf ratios of $\mathrm{Na}, \mathrm{Fe}, \mathrm{Mn}$, and $\mathrm{Al}$ in dieback interior marshes were significantly elevated compared to adjacent shorelines and to control marshes in August-October 2000 (fig. 19, table 3). On subsequent sampling of dieback areas, leaf ratios in recovering plants had decreased to control levels. These data indicate that plants growing in interior dieback marshes took up relatively more potentially toxic metals and cations during the dieback event in 2000 but not during recovery in 2001.

\section{Vegetative Recovery}

Surveys conducted in April and September 2001 showed substantial recovery in the transition zone and no evidence of dieback expansion at any of the original sites (fig. 8). The rapid recovery of the transition zone may be due to the high survival of rhizomes (fig. 10). Recovery of interior dieback zones was highly variable, however, and ranged from 0 to 73 percent live cover in experimental plots by September 2001 (fig. 9). At least half of the dieback sites remained almost completely unvegetated in September 2001 (fig. 20), indicating that S. alterniflora rhizomes had not survived and that revegetation would have to occur via seeding or vegetative expansion from edges. Seedlings of S. alterniflora were observed in several dieback sites (fig. 20C) and may ultimately lead to revegetation. Those sites that had substantially recovered by September 2001 may have done so through vegetative expansion from surviving rhizomes (fig. 21), although a distinction could not always be made between seedling and rhizome regeneration after 1 year's growth. Where there was recovery of dieback areas by $S$. alterniflora, the regenerating plants were robust (culm heights $\geq 1.5 \mathrm{~m}$ ), and reproductive output was high (fig. 22). Vigorous growth in former dieback sites may be attributable to a greater availability of nutrients and/or light in the dieback areas and indicates that post-dieback soil conditions will not limit recovery of $S$. alterniflora. Stands of J. roemerianus, D. spicata, and A. germinans within or near some dieback sites remained largely unchanged or expanded into the dead $S$. alterniflora marsh during the observation interval.

\section{Causation}

The cause of the acute dieback of $S$. alterniflora is currently unknown. However, our data either eliminate or are inconsistent with some proposed causes. Based on the pattern of dieback and the large spatial extent, natural sources of plant stress or disturbance that could have a regionwide effect were the main focus of investigation. 
Table 20. Factor analysis of plant elemental concentrations measured at all sites (1-21) and zones (healthy shoreline [HS], transition [T], dieback interior [DI], dieback shoreline [DS], regenerating [R], control shoreline [CS], control interior [CI]) in August 2000, April 2001, and September 2001. Principal component analysis was used to reduce the number of variables and multicollinearity. Elements with values below detection limits $(\mathrm{Mo}, \mathrm{Ni}, \mathrm{Pb})$ or missing values $(\mathrm{S})$ were excluded from the analysis. The rotated factor pattern is given for each date. Individual factor scores were subjected to repeated measures ANOVA with site, zone (nested within site), and time as grouping factors. F-ratios for main effects and $1 \mathrm{DF}$ contrasts are given below the factor patterns; significance is indicated by $*(\mathrm{p} \leq 0.05), * *(\mathrm{p} \leq 0.01), * * *(\mathrm{p} \leq 0.001), * * * *(\mathrm{p} \leq 0.0001)$, or ns (not significant).

\begin{tabular}{|c|c|c|c|c|c|c|c|c|c|c|}
\hline \multirow[b]{2}{*}{ Element: } & \multicolumn{3}{|c|}{ August 2000} & \multicolumn{3}{|c|}{ April 2001} & \multicolumn{4}{|c|}{ September 2001} \\
\hline & Factor 1 & Factor 2 & Factor 3 & Factor 1 & Factor 2 & Factor 3 & Factor 1 & Factor 2 & Factor 3 & Factor 4 \\
\hline $\mathrm{Al}$ & 0.33 & -0.73 & -0.08 & -0.85 & 0.06 & -0.21 & -0.03 & 0.04 & 0.79 & -0.10 \\
\hline $\mathrm{Ca}$ & 0.71 & 0.12 & -0.06 & -0.04 & 0.92 & 0.23 & -0.92 & -0.18 & 0.07 & 0.19 \\
\hline $\mathrm{Cu}$ & -0.81 & -0.30 & 0.06 & -0.27 & 0.04 & 0.75 & -0.02 & 0.54 & -0.09 & 0.11 \\
\hline $\mathrm{Fe}$ & -0.38 & -0.68 & 0.03 & -0.87 & -0.14 & -0.3 & -0.04 & -0.03 & 0.79 & 0.20 \\
\hline $\mathrm{K}$ & 0.28 & 0.75 & 0.02 & 0.50 & -0.03 & 0.74 & 0.13 & 0.81 & -0.12 & 0.12 \\
\hline $\mathrm{Mg}$ & 0.85 & -0.07 & 0.16 & 0.01 & 0.89 & 0.13 & -0.88 & 0.17 & 0.08 & -0.11 \\
\hline Mn & 0.03 & 0.09 & -0.84 & -0.55 & 0.39 & -0.08 & -0.45 & -0.51 & -0.15 & 0.11 \\
\hline $\mathrm{Na}$ & 0.01 & 0.02 & 0.87 & 0.31 & 0.24 & 0.69 & -0.14 & -0.04 & 0.34 & 0.76 \\
\hline $\mathrm{P}$ & 0.15 & 0.67 & -0.04 & 0.07 & 0.35 & 0.61 & -0.12 & 0.69 & 0.22 & -0.11 \\
\hline $\mathrm{Zn}$ & -0.78 & -0.16 & 0.06 & -0.68 & -0.04 & 0.32 & 0.03 & 0.12 & -0.14 & 0.74 \\
\hline $\begin{array}{l}\text { Cumulative percen } \\
\text { of variance explain }\end{array}$ & ned 28 & 50 & 65 & 27 & 46 & 69 & 19 & 36 & 51 & 64 \\
\hline \multicolumn{11}{|l|}{ ANOVA Source: } \\
\hline Site & \multicolumn{3}{|c|}{$40.78 * * * * 16.82 * * * * 104.6 * * * *$} & \multicolumn{3}{|c|}{$22.74 * * * * 13.05 * * * * 14.93 * * * *$} & \multicolumn{4}{|c|}{$12.84 * * * * 34.68 * * * * 14.06 * * * * 6.9 * * * *$} \\
\hline Zone (site) & \multirow{2}{*}{\multicolumn{3}{|c|}{$6.55 * * * * 11.22 * * * * 11.12 * * * *$}} & \multirow{2}{*}{\multicolumn{3}{|c|}{$15.18 * * * * \quad 7.17 * * * * 4.09 * * *$}} & \multicolumn{4}{|c|}{$7.12 * * * * \quad 4.96 * * * * 5.06 * * * * 3.12 * * * *$} \\
\hline \multicolumn{5}{|l|}{ Contrasts: } & & & & & & \\
\hline HS vs. DI & $4.50 *$ & \multicolumn{2}{|c|}{$60.18 * * * * 4.82 * *$} & \multicolumn{3}{|c|}{$155.0 * * * * 57.30 * * * * 6.60 *$} & \multicolumn{4}{|c|}{$14.59 * * * * 0.20 \mathrm{~ns} 24.42 * * * * 0.51 \mathrm{~ns}$} \\
\hline HS vs. T & $0.30 \mathrm{~ns}$ & $0.94 \mathrm{~ns}$ & $22.44^{*}$ & $17.51 *$ & $* * * 1.03 \mathrm{n}$ & $\mathrm{s} \quad 0.01 \mathrm{~ns}$ & $0.15 \mathrm{~ns}$ & s $6.61 *$ & $9.52 * *$ & $* 5.54 *$ \\
\hline DI vs. CI & $2.10 \mathrm{~ns}$ & $0.22 \mathrm{~ns}$ & $0.43 \mathrm{~ns}$ & \multicolumn{3}{|c|}{$57.79 * * * * 61.85 * * * * 12.36 * * *$} & $10.68 * *$ & \multicolumn{3}{|c|}{$22.51 * * * * 19.3 * * * * 14.4 * * * *$} \\
\hline Dieback vs. Contrc & ol $4.73 *$ & $3.54 *$ & $0.69 \mathrm{~ns}$ & \multicolumn{3}{|c|}{$31.40 * * * * 15.21 * * * 15.70 * * *$} & $0.68 \mathrm{~ns}$ & \multicolumn{3}{|c|}{$4.66 * * 23.16 * * * * 6.96 * *$} \\
\hline
\end{tabular}



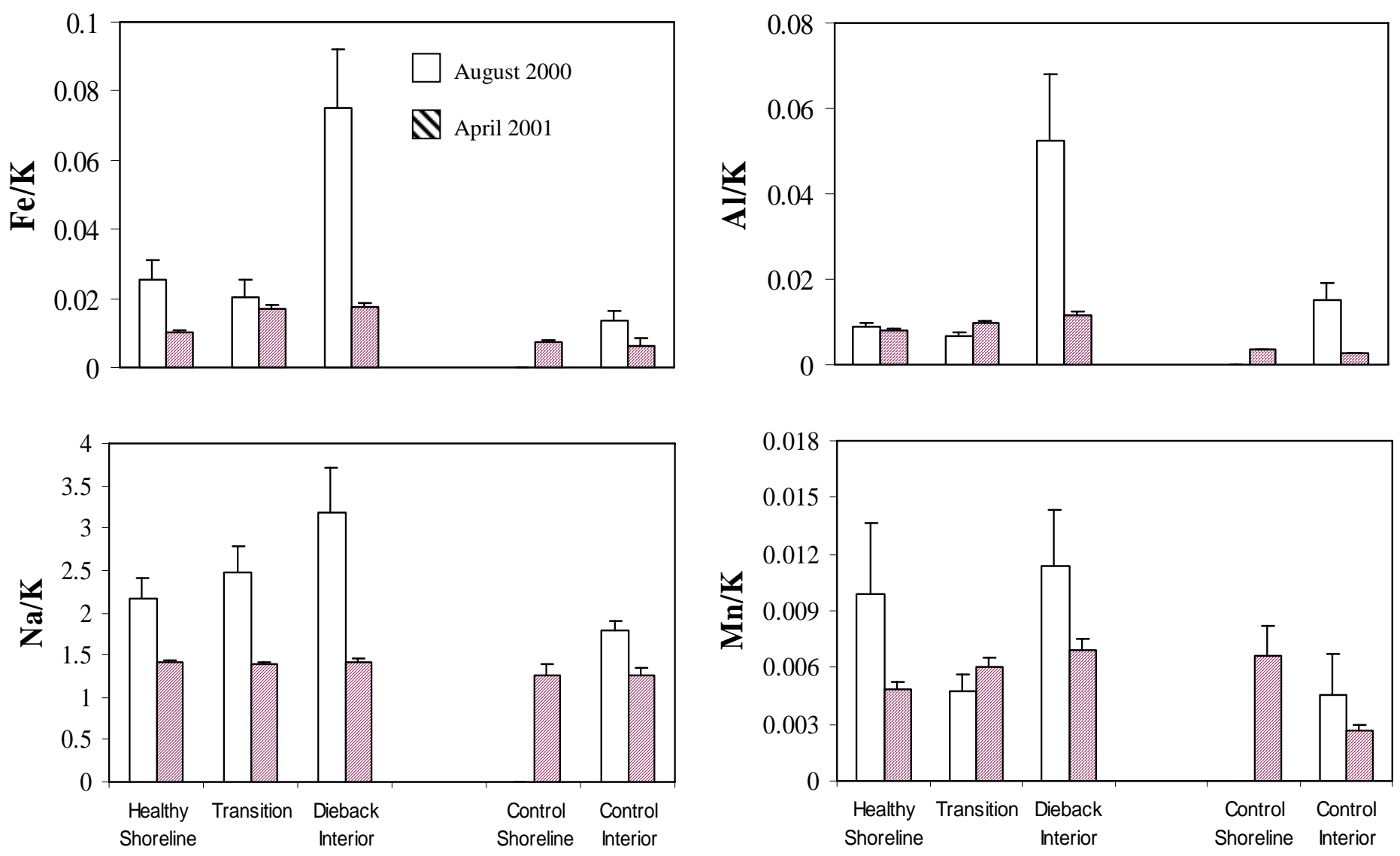

Figure 19. Elemental concentration ratios measured in Spartina alterniflora (smooth cordgrass) leaves in August 2000 and April 2001 at dieback and reference marshes. Three zones were sampled at dieback areas and two zones at control (no visible dieback) areas. Values are the mean \pm 1 SE $(n=48-51$ dieback, $n=9$ control). 


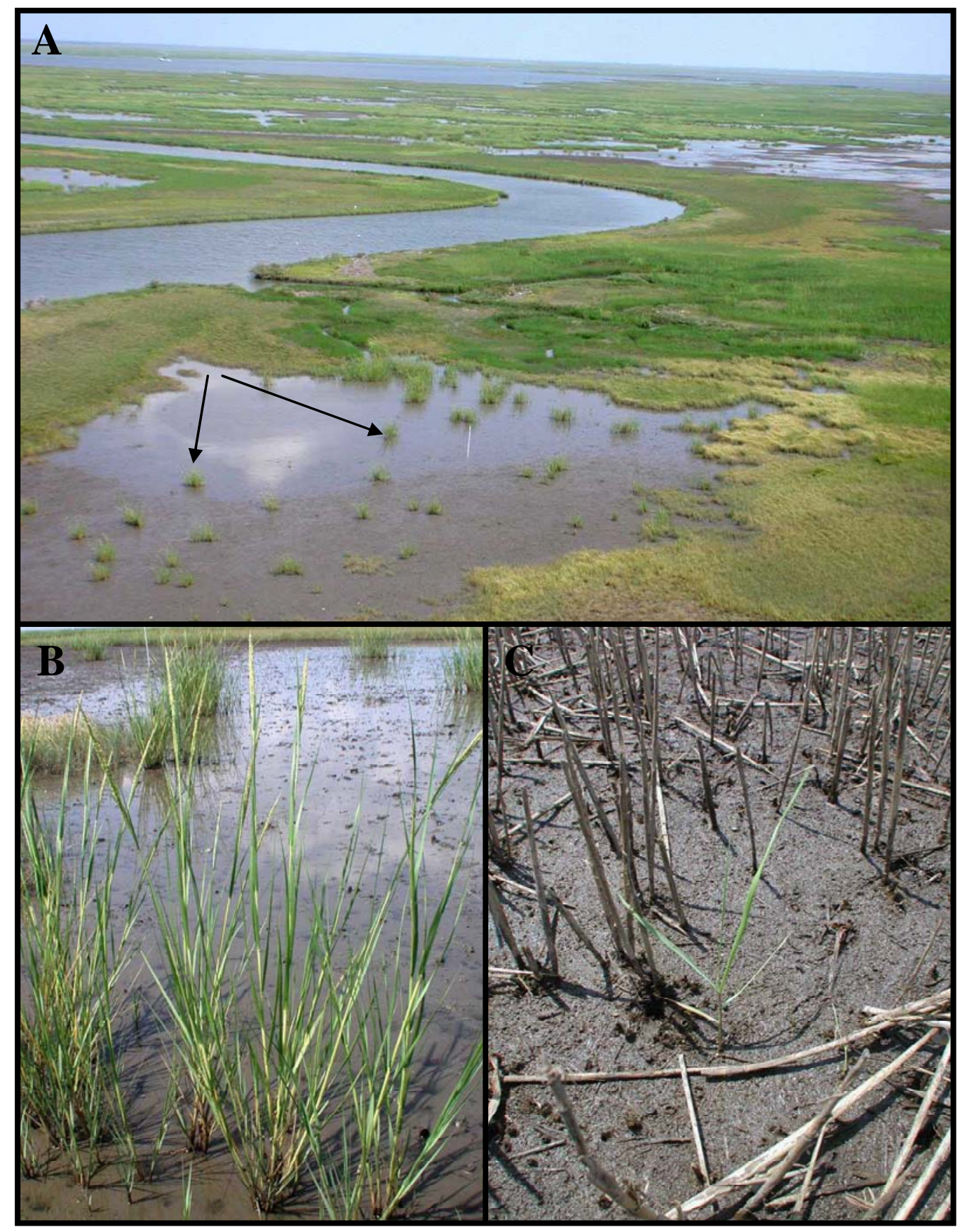

Figure 20. Aerial and ground views of a dieback area (site 6) that showed little vegetative recovery in September 2001; however, small clumps (arrows) of Spartina alterniflora (smooth cordgrass) (A) have initiated from surviving rhizomes (B) or seedlings (C). 


\section{A. October 2000}

\section{$0 \%$ live cover}
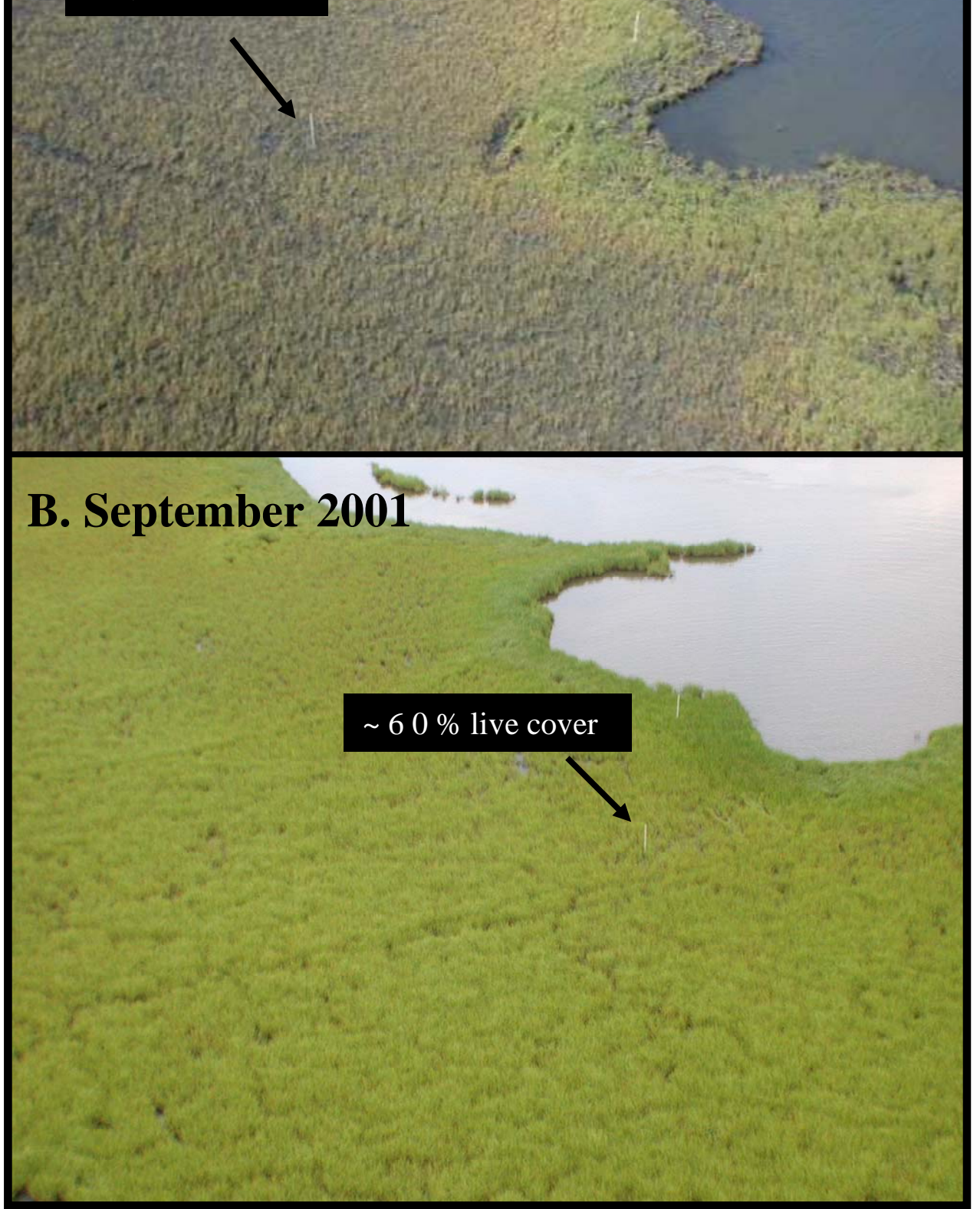

Figure 21. Example of a Spartina alterniflora (smooth cordgrass) marsh (site 17) that recovered from dieback. Arrows indicate the same position in both panels. 


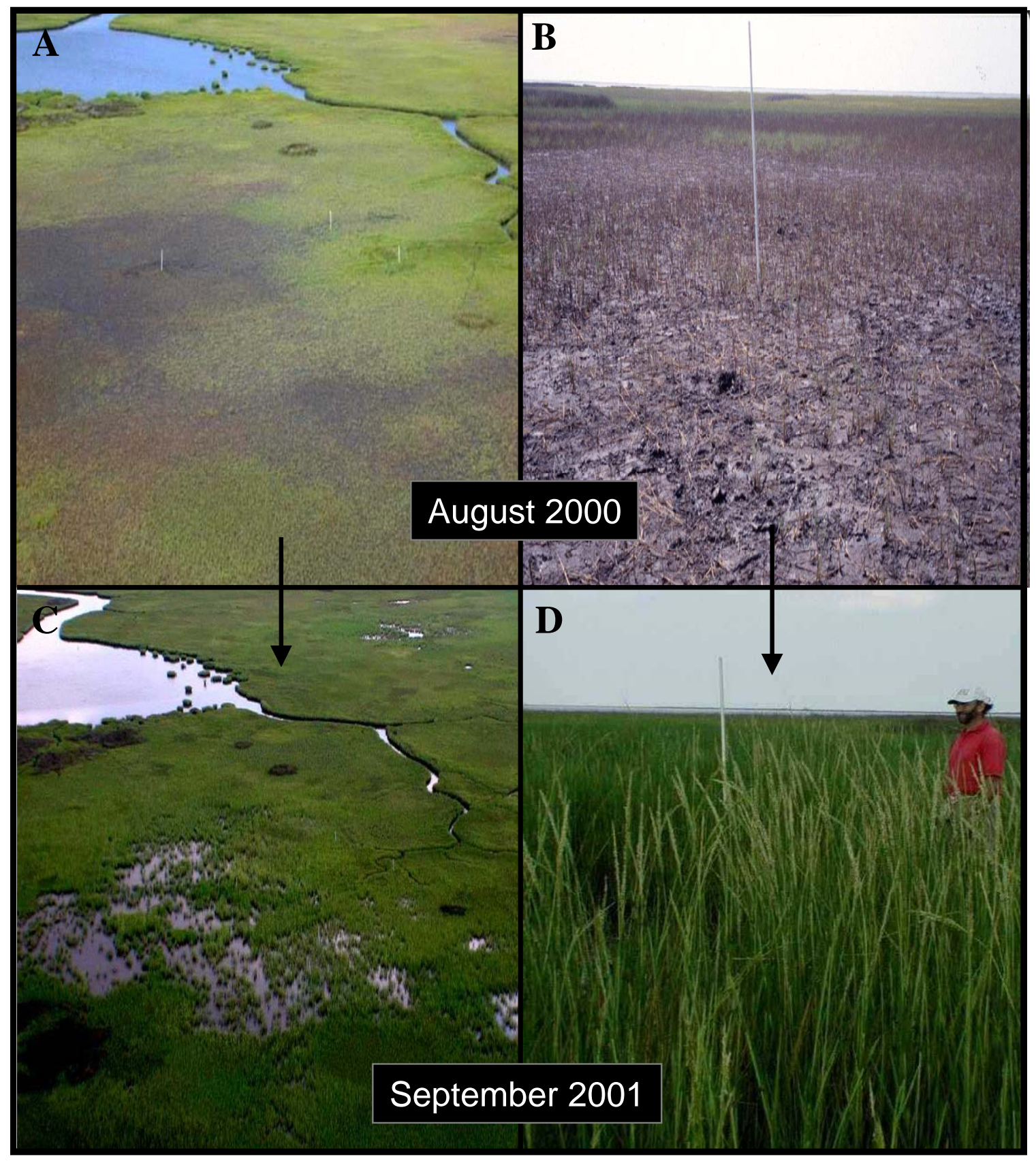

Figure 22. Aerial and ground views of a Spartina alterniflora (smooth cordgrass) marsh (site 2) recovering from dieback. Note height and flowering of the plant shoots in panel D. Arrows connect aerial and ground views between two dates (August 2000 during the dieback and September 2001 during recovery). 
Each of the three hypotheses posed in the introduction was tested by using the data collected during preliminary and intensive surveys. Our approach was to consider potential factors in terms of consistency with the spatial pattern of dieback (primarily salt marsh; interior vs. shoreline vegetation), the relative vulnerability of marsh species (Spartina spp. vs. other marsh species), and the temporal sequence of dieback and recovery.

Hypothesis 1: Biotic Agents

Bacterial, fungal, or viral pathogens or insect outbreaks may cause widespread mortality of plants. In Florida, a fungal pathogen was identified in connection with Spartina dieback, but the direct demonstration of pathogenicity has not been made (Carlson and others, 2001). Examination of plant shoots and roots collected from dieback marshes in Louisiana revealed a variety of fungal species (e.g., Fusarium sp. and Macrophomina sp.; R. Schneider, Louisiana State University, personal communication). Although potential fungal pathogens were isolated from S. alterniflora, infection by these organisms usually occurs on previously stressed vegetation and is therefore unlikely to be an explanation by itself. Fungal or other pathogens also cannot explain the consistent local pattern of dieback with living vegetation along shorelines and creeks and abrupt transition to dead vegetation in the marsh interior. However, fungal pathogens may have played a secondary role in plant mortality through interaction with an abiotic stress factor, and experiments are needed to test the pathogenicity of isolates from plant material collected in this survey.

Outbreaks of insects or other herbivores were also quickly ruled out as potential causes, primarily because of the spatial pattern and extent of dieback as well as the condition of dead and dying vegetation. No evidence of insect damage sufficient to cause dieback was observed at any of the dieback sites examined in June 2000 (Bay Junop) or August 2000 (intensive survey). In particular, plant shoots collected from Bay Junop early in the dieback sequence were completely dead (i.e., no green tissue) but were largely intact with unfrayed leaves and no consistent signs of necrotic lesions, abrasions, holes, or other damage indicative of excessive herbivory.

The marsh periwinkle, Littoraria irrorata, has been specifically suggested as a cause of marsh dieback in Louisiana (Bertness and Silliman, 2002); however, our observations do not support this explanation. Although snails had heavily grazed the dead vegetation in some sites by August 2000, the mortality of the vegetation clearly preceded the grazing, as observed at Bay Junop in June 2000. The temporal sequence suggests instead that snails responded to dieback of vegetation (fig. 23). In June 2000, dieback sites had standing dead vegetation with no evidence of heavy grazing (figs. 3). By August 2000, seven of nine dieback marshes had been reduced to stubble or bare ground, but two sites still had standing dead shoots with leaves (fig. 9A). Site 1, which was dominated by $S$. patens, retained standing dead shoots much longer than did sites dominated by $S$. alterniflora (fig. 9). Qualitative observations indicated high variability among sites in snail densities and no obvious patterns relative to dieback. 


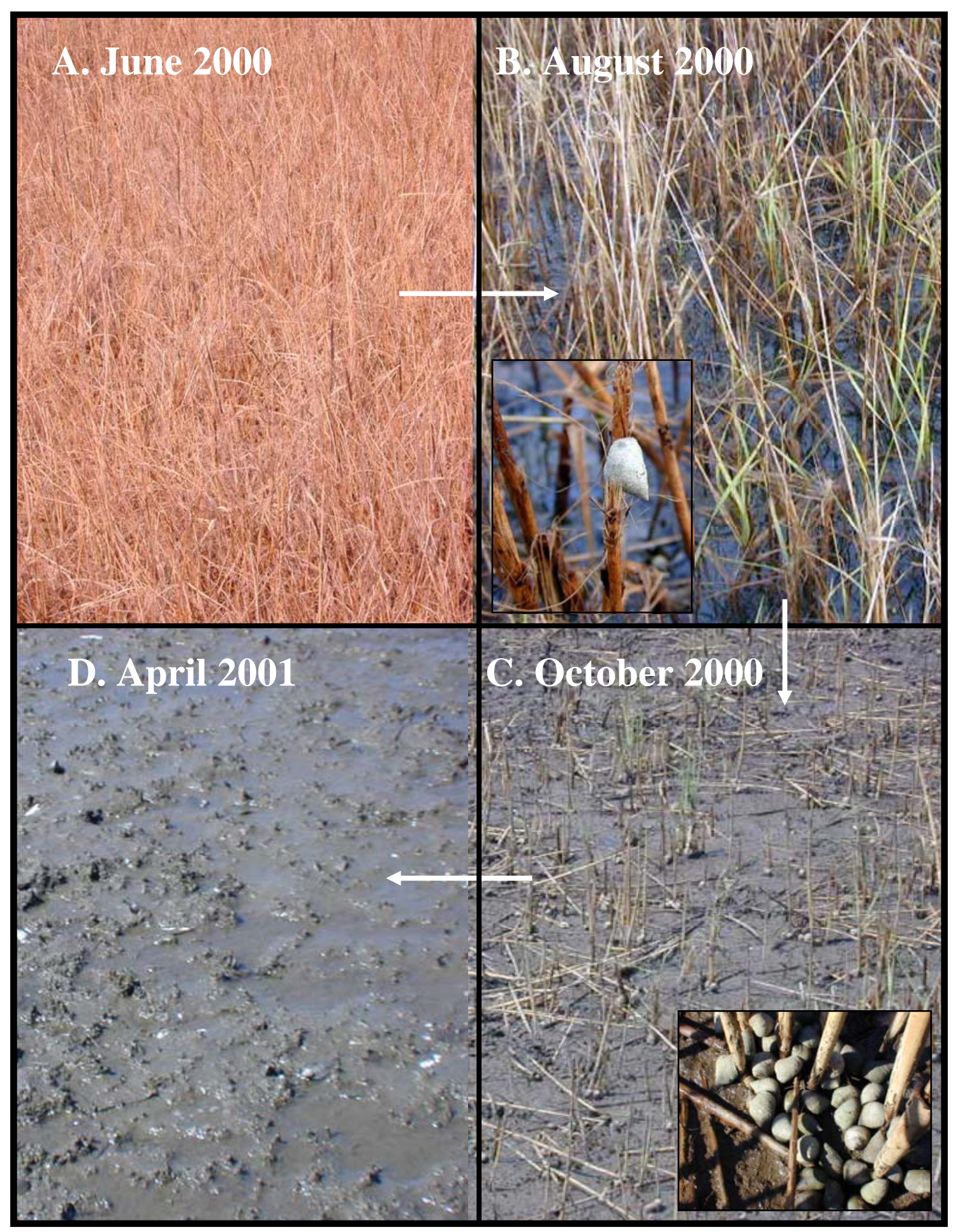

Figure 23. Littoraria irrorata (marsh periwinkle) responded to rather than caused marsh dieback. Spartina alterniflora (smooth cordgrass) shoots died in spring of 2000 and showed no signs of grazing by snails or other herbivores (A). By August 2000, snails had begun grazing on dead shoots (B), which were reduced to stubble by October 2000 (C) and to mudflats by April 2001 (D). Arrows indicate the sequence of stages in degradation of dead marsh plants. Inset photos in (B) and (C) show close-ups of L. irrorata. 
By October 2000, very little standing vegetation was left in interior dieback sites, but snails remained bunched around the stem remnants in some of these developing mudflats (fig. 23C) and had not moved into the nearby healthy stands along the shoreline. If overgrazing by snails were the cause of the dieback, then some expansion of plant mortality should have occurred as their food source dwindled. Dieback expansion not only did not occur, but by April 2001, the transition zone at all dieback sites had completely recovered (fig. 8). Snails were undoubtedly instrumental in the rapid degradation of dead shoots in dieback marshes and likely contributed to the variation among sites in dead shoot condition (figs. 7-9), but they were not the cause of the dieback. Thus, our data are inconsistent with Hypothesis 1 that marsh dieback was primarily caused by a biotic process. However, we cannot exclude the possibility that fungal pathogens interacted with an environmental stress factor to cause plant mortality.

\section{Hypothesis 2: Excessive Waterlogging and Sulfide Toxicity}

The pattern of interior dieback with surviving vegetation along the shoreline suggests that a hydroedaphic factor may have caused the dieback or, conversely, may have ameliorated the causative agent. Shoreline vegetation experiences more frequent and deeper soil flushing during a tidal cycle than does the marsh interior where sulfide and other toxins may accumulate and affect root metabolism (Mendelssohn and others, 1981). Although above-normal flooding depths were not indicated by water level records for the affected region (E. Swenson, public communication, http://www.brownmarsh .net), historical conditions of soil waterlogging could have increased overall plant stress in interior marshes and decreased ability to cope with additional stressors (Mendelssohn and others, 1981). Previous work has clearly demonstrated the role of excessive soil waterlogging and sulfide in reduced growth and historical dieback of $S$. alterniflora in interior marshes (see Mendelssohn and Morris, 2000 for a review).

Although soil reduction-oxidation status $\left(E_{\mathrm{h}}\right)$ was not substantially different in the interior dead zones from that in healthy or transition zones (fig. 14, tables 4-6), sulfide concentrations were significantly elevated in the dead and transition zones at most sites (fig. 15, tables 4-6). Sulfide concentration in some dieback areas exceeded that known to cause growth reductions in $S$. alterniflora ( 1 mM; Koch and others, 1990), but it is unknown if sulfide exceeded a lethal concentration prior to sampling. Observations at Bay Junop in June 2000, however, suggest that sulfide concentrations were not more elevated in dieback areas earlier in the year. At this site, sulfide concentrations were highest within the dead marsh zone and lowest in the healthy mangrove stand and along the shoreline where $S$. alterniflora shoots were still alive. However, this pattern cannot be interpreted as a cause and effect relationship between sulfide and marsh dieback for several reasons. First, there was a gradual increase in sulfide with distance from the shoreline, which is typical of salt marshes in Louisiana (Mendelssohn and others, 1981). This pattern does not match the spatial dieback pattern in which there was an abrupt transition from living plants to completely dead vegetation across a narrow transition zone. Second, the sulfide concentrations across much of the dead marsh in June 2000 were lower than that known to reduce growth of $S$. alterniflora (Koch and others, 1990). Third, because living vegetation influences soil aeration via oxygen leakage from roots, sulfide may have accumulated in the dead marsh simply because root aeration was not occurring. Similarly, the lower sulfide concentrations within the healthy mangrove stand can be attributed to the root aeration effect of healthy A. germinans, which has been demonstrated in tropical mangrove systems (McKee and others, 1988). Fourth, death of the 
vegetation may stimulate sulfate reduction, so that sulfide concentrations become elevated wherever the marsh plants have died. Fifth, sulfide concentrations remained elevated or even increased over time at dieback sites that ultimately recovered (e.g., sites 2, 7, and 17; fig. 15). If reducing conditions and elevated sulfide were responsible for the acute dieback of salt marshes, then it is unlikely that vegetative recovery would occur under those same soil conditions. Finally, although sulfide concentrations were elevated in dieback marshes dominated by S. alterniflora, they were extremely low in the dead $S$. patens marsh (site 1), and redox potentials indicated oxidizing, rather than reducing, conditions. For the reasons stated above, we reject Hypothesis 2, particularly with respect to sulfide as a primary cause of acute salt marsh dieback, but cannot eliminate excessive soil waterlogging as a factor that may have predisposed interior marshes to the causative agent.

\section{Hypothesis 3: Low Water Levels and Drought}

Marsh dieback coincided with extreme drought conditions and unusually low freshwater discharge from the Mississippi and Atchafalaya Rivers that prevailed during the previous year (E. Swenson, public communication, http://www.brownmarsh.net). These local events are related to La Niña, a phenomenon that is characterized by drier and warmer than normal conditions across the southern United States (Philander, 1990). Mean high tide levels in coastal Louisiana were also below normal during early spring 2000 (E. Swenson, public communication, http://www.brownmarsh.net), and this factor could have limited over-bank flooding of interior marshes. Drought, combined with less tidal flooding, may have decreased water availability directly and/or increased salinity by concentrating salts in the pore water. Salinity of surface water prior to and during dieback (E. Swenson, public communication-http://www.brownmarsh.net) and measured in pore water during our survey (figs. 13 and 15) did not exceed the tolerance limits of S. alterniflora (Hester and others, 1996). Leaf $\mathrm{Na} / \mathrm{K}$ ratios in dieback sites were significantly higher than those in healthy shoreline plants (fig. 19) and higher than those of plants grown at 30 $\% o$ in greenhouse experiments (Hester, 1995). These results indicate that salinity was elevated in the interior marshes sufficiently to alter cation balance but do not demonstrate that hypersalinity caused mortality. Furthermore, although survival of more salt tolerant species (e.g., D. spicata and A. germinans) is consistent with the salinity hypothesis, survival of J. roemerianus, which is less salt tolerant than $S$. alterniflora, is not. Variation in species vulnerability to dieback could reflect differences in rooting depth and exposure to high salinity in surface soils. Decreased rooting depth of $S$. alterniflora from shoreline $(37 \pm 2 \mathrm{~cm})$ to transition $(28 \pm 1 \mathrm{~cm})$ to marsh interior $(25 \pm 1 \mathrm{~cm})$ paralleled shoot mortality (fig. 24). However, species unaffected by the dieback, such as $A$. germinans and $J$. roemerianus, growing within Spartina dieback zones also had shallow root systems (14 \pm 1 and $9 \pm 1 \mathrm{~cm}$, respectively) (fig. 25). 


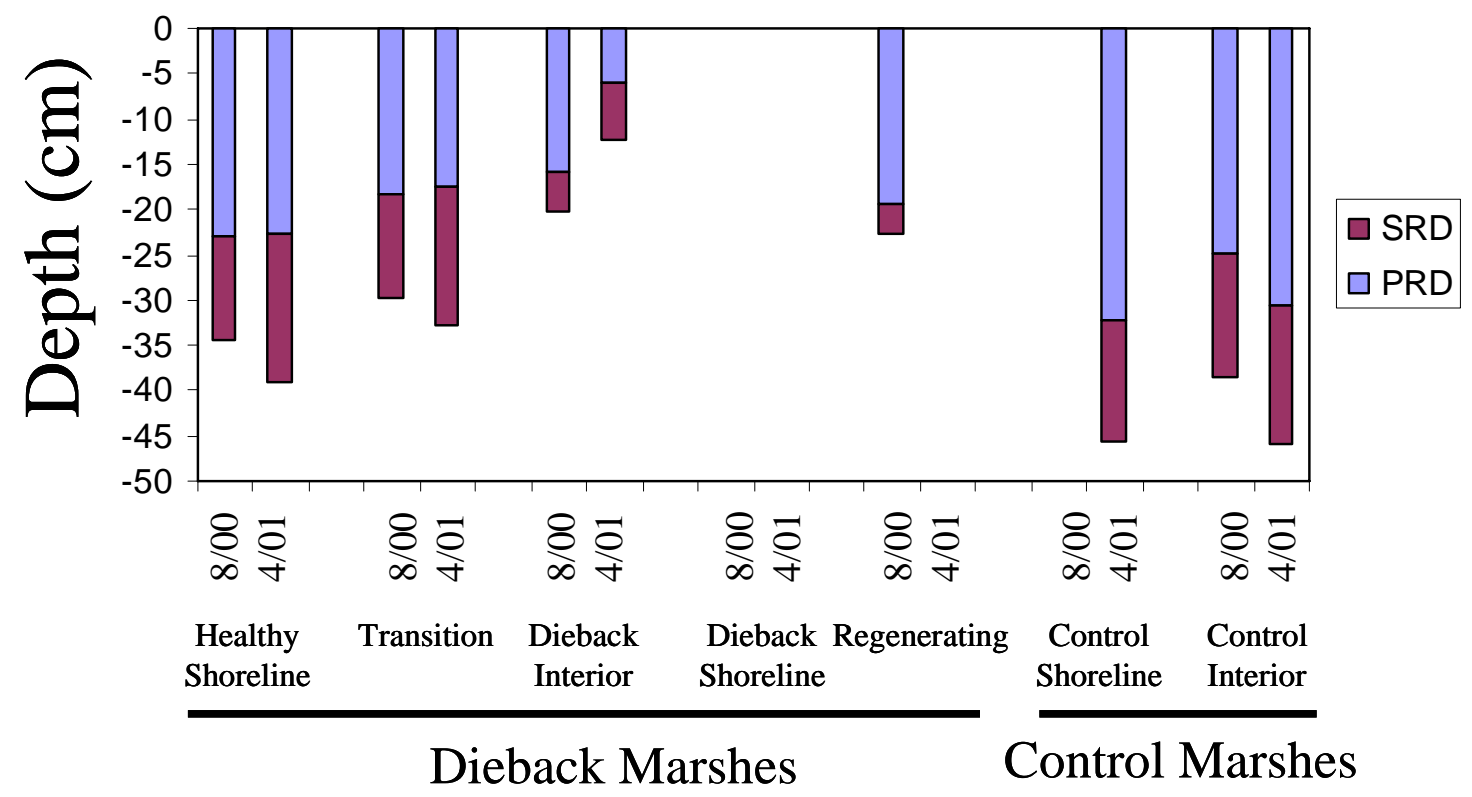

Figure 24. Primary rooting depth (PRD) and secondary rooting depth (SRD) in various zones at dieback and control marshes in August 2000. Values are the mean \pm 1 SE $(n=48-54$ at healthy shoreline, transition, and dieback interior marshes, $n=3-9$ at other dieback zones and control marshes). 


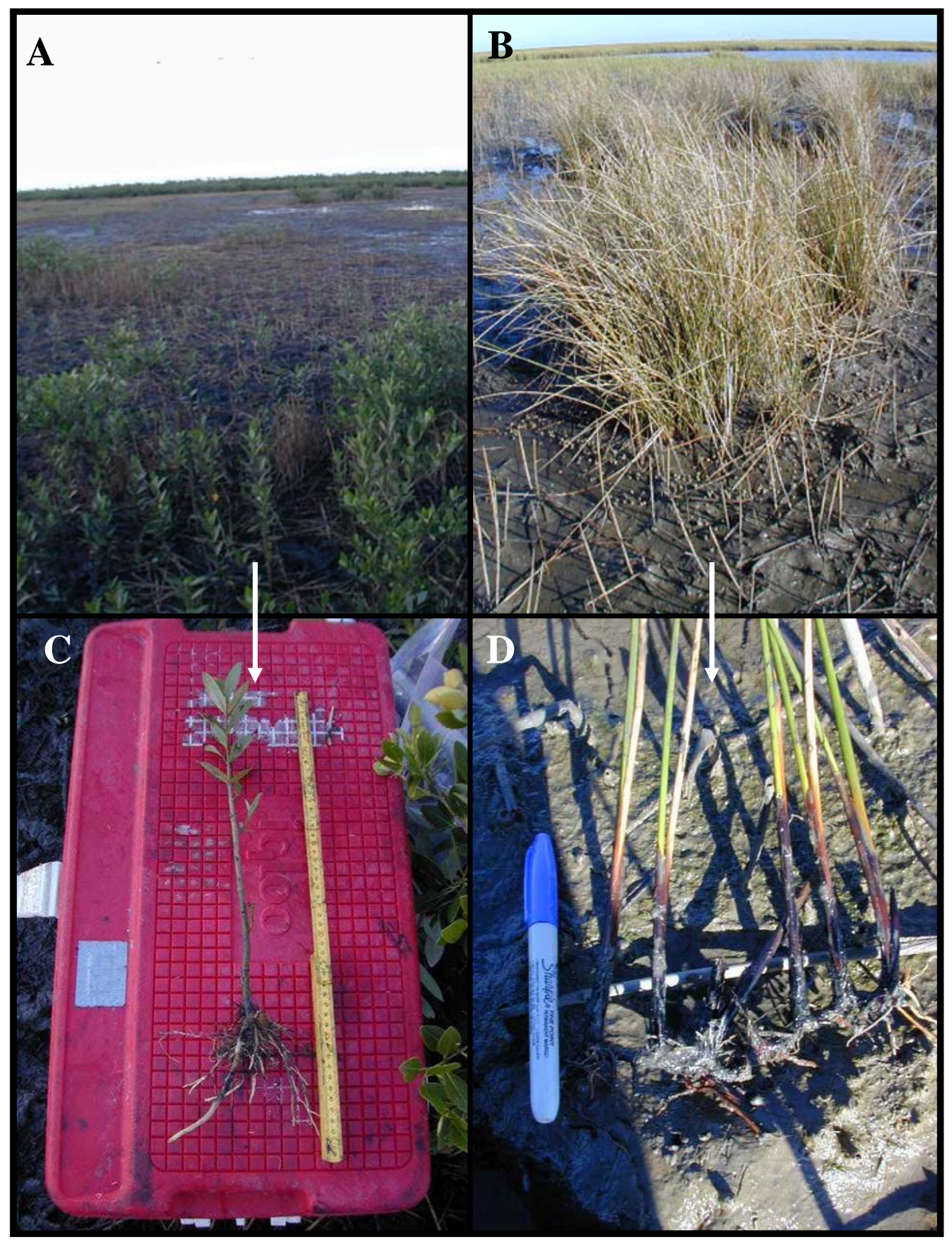

Figure 25. Views of Avicennia germinans (black mangrove) (A) and Juncus roemerianus (needlegrass rush) (B) growing within Spartina alterniflora (smooth cordgrass) dieback areas and their respective root systems $(C$ and $D)$. The ruler in $C$ is $0.5 \mathrm{~m}$. 
Thus, a shallow root system cannot explain the greater vulnerability of S. alterniflora in interior marshes to acute dieback but may indicate a preexisting stress condition in interior marshes such as elevated sulfide or salinity that predisposed plants to dieback. Thus, although salinity may have been elevated in interior marshes prior to or during the dieback event and increased plant stress, the species pattern of response does not support hypersalinity as the primary causative agent.

Besides salinity, other chemical changes may occur upon soil drying. Sediments that develop under an estuarine influence may contain pyrite or other readily oxidizable metal-sulfide compounds (Howarth, 1979). When saline sediments are aerated, e.g., during drainage or dredging, microbial oxidation of pyrite and metal sulfides generates sulfuric acid, which leads to soil acidification (Nordstrom, 1982). Aeration and acidification of sediments (to $\mathrm{pH} 3-4$ ) may also occur naturally through oxygen advection by falling water, a process observed during early spring in Louisiana coastal marshes (Feijtel and others, 1988a). By the time of our initial surveys, all but one site was flooded and showed no evidence of drying or cracking. However, this one site (dominated by $S$. patens) showed evidence in August 2000 of soil desiccation in dead and transition zones with low soil $\mathrm{pH}(\sim 4)$, high soil $E_{\mathrm{h}}(>600 \mathrm{mV})$ and root coatings of ferric iron, indicating oxidation (fig. 26). Another site (dominated by S. alterniflora) also showed dry, cracked soil in the dead, interior marsh zone as well as along a creekbank in April 2001 (fig. 27). These observations indicate that soil drying can occur in these marshes under certain conditions. Subsequent reflooding and mixing with alkaline seawater as well as reduction reactions would cause $\mathrm{pH}$ to rise (Gambrell and Patrick, 1978), which could explain why flooded sites had near-neutral pH at the time of our surveys.

Dieback soils consistently had higher concentrations of pyrite and acid-extractable Fe and $\mathrm{Al}$ and lower organic matter contents compared to control marshes (figs. 16-17, Tables 8-10). Solubility of $\mathrm{Fe}, \mathrm{Mn}$, and $\mathrm{Al}$ increases several fold with decreases in $\mathrm{pH}$ and may reach toxic levels (Gambrell and Patrick, 1978). Similar concentrations of pyrite and acid-extractable Fe and $\mathrm{Al}$ in healthy shoreline and interior dieback zones indicate that the potential for soil acidification and metal release was the same but that differences in hydrology may have prevented the streamside soils from becoming acidified and/or metals reaching toxic concentrations.

Lower concentrations of pyrite in control marshes would decrease the potential for soil acidification upon drying and oxidation, and higher organic matter would promote formation of insoluble complexes with metals (Adriano, 1986). The significantly higher leaf ratios of Fe:K and $\mathrm{Al}: \mathrm{K}$ measured in interior dieback marshes in August 2000 and subsequent return to control levels in April and September 2001 is consistent with this scenario (fig. 19). The orange to reddish coloration of dying marsh vegetation (fig. 4) was also reminiscent of the leaf discoloration ("bronzing") described in rice (Oryza sativa) affected by Fe toxicity (Jugsujinda and Patrick, 1993). Salt marsh sediments accumulate more trace and heavy metals because of mineral input from rivers than do intermediate and freshwater marshes with more organic substrates (Feijtel and others, 1988b), and salt marsh sediments also show greater decreases in $\mathrm{pH}$ upon oxidation (Feijtel and others, 1988a). These factors could explain why acute dieback was more prevalent in saline marshes. 


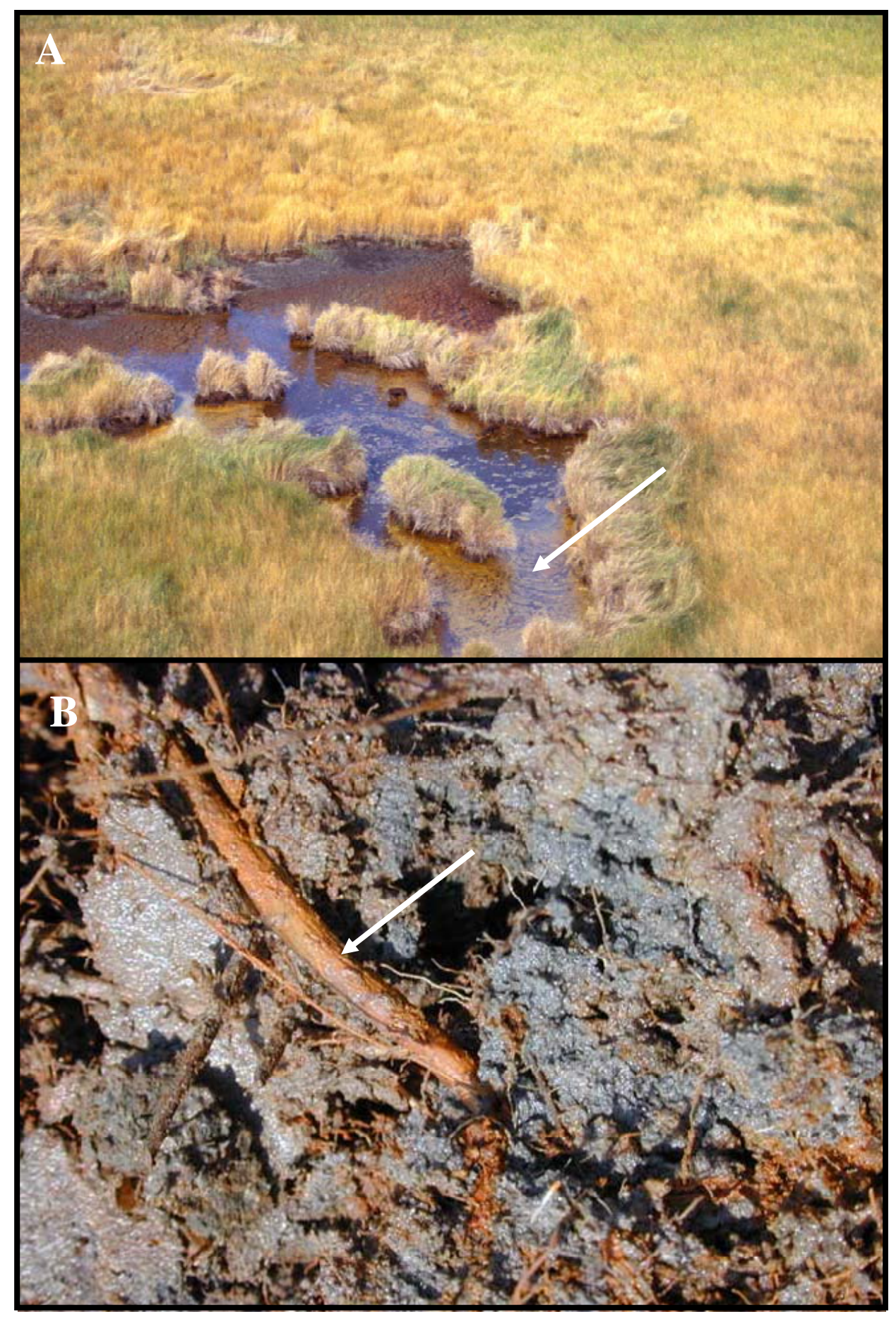

Figure 26. Reddish-orange coloration observed in the shoots (A) and soil (B) at some sites during early stages of dieback (August 2000). Arrows point to ferric iron deposits on the water surface and roots (upper and lower panels, respectively), indicative of oxidation. 


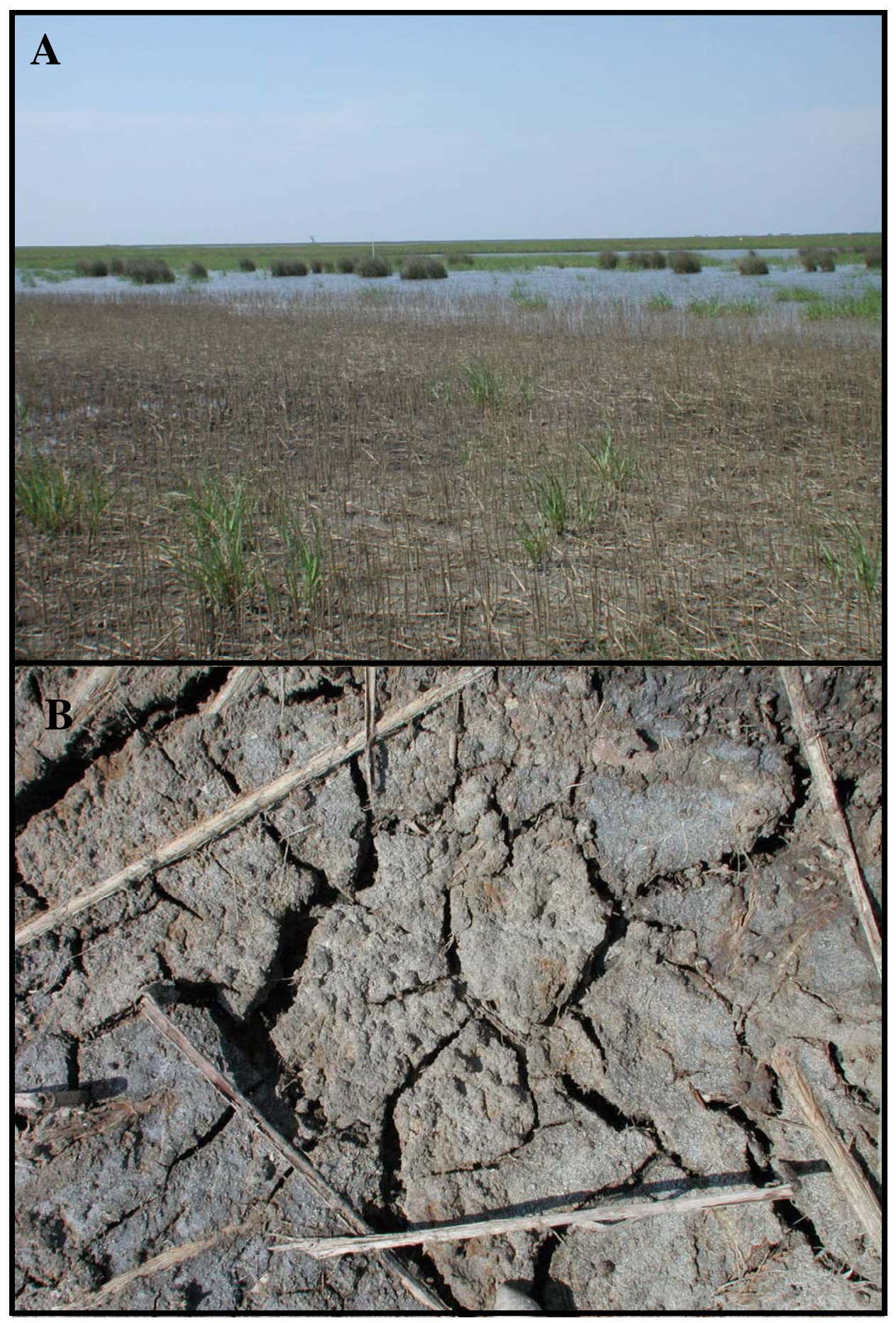

Figure 27. Distant (A) and close-up (B) views of dry, cracked soil at a Spartina alterniflora (smooth cordgrass) dieback area (site 16). 
The most compelling evidence for soil acidification and possible involvement in Spartina spp. mortality, however, is that soils from dieback areas acidified upon oxidation, whereas those from control sites did not (fig. 18). The acidification phase in early spring could have been prolonged or exaggerated by drought conditions sufficiently to affect plants, either by acidity per se or by toxic metals released at low $\mathrm{pH}$.

Our findings are thus most consistent with Hypothesis 3 that soil acidification as a consequence of drought and low tide levels and release of toxic metals caused dieback of saline marshes. However, a direct lack of water and/or hypersalinity could have contributed to the overall stress on plants and their potential vulnerability to low $\mathrm{pH}$ and metal toxicity. These hypotheses still require further testing to evaluate the relative tolerance limits of $S$. alterniflora and other salt marsh species to low $\mathrm{pH}$ and metals.

\section{Conclusions}

Intensive examination of plant and soil characteristics at multiple dieback sites provided some important insights into the dieback process, vegetative recovery, and causation. Some areas of salt marsh were completely dead by June 2000, and plant shoots were substantially decomposed in most dieback sites by August 2000. This timeline of vegetative condition supports the hypothesis that the dieback event began in early spring of 2000. This study also confirmed that spatial patterns of dieback (interior vs. shoreline marsh) and differential species susceptibility (Spartina spp. vs. other salt marsh species) occurred repeatedly across the Barataria-Terrebonne estuarine system. The documentation of consistent patterns is important to concurrent research on causation and supports the hypothesis that the cause was a regional factor (e.g., drought) that interacted with local patterns of soil chemistry and/or hydrology.

Little or no expansion of dieback occurred subsequent to the initial event, and areas with moderate dieback ( $~ 50$ percent mortality) had completely recovered by April 2001. These data demonstrate the ephemeral nature of the dieback agent, which apparently had no residual effects to limit plant recovery. Rapid recovery of moderately impacted marsh was due to survival of $S$. alterniflora rhizomes. Slow recovery of interior marshes that experienced greater than 90 percent shoot mortality was attributable to low survival of rhizomes and variable recolonization by seedlings and/or vegetative expansion from edges. However, regenerating plants in dieback areas were robust (culm heights $\geq 1.5 \mathrm{~m}$ ), and reproductive output was high; these factors indicate that post-dieback conditions were actually promoting growth of $S$. alterniflora. Vigorous growth in dieback areas was likely due to a greater availability of nutrients and/or light. Stands of $J$. roemerianus, $D$. spicata, and A. germinans within or near some dieback sites remained largely unchanged or expanded into the dead S. alterniflora marsh during the observation interval. Although further monitoring is needed to confirm the extent of recovery, our observations indicate a high potential for natural recovery from the dieback event. However, some areas that showed no recovery by September 2001 (one full growing season after dieback) may convert to open water.

The cause of the dieback is currently unknown, primarily because the causative agent left no conclusive signature in plant or soil variables. Soil conditions were generally within normal ranges for salt marshes during the dieback event (June to October 2000) and during vegetative 
recovery (April to September 2001). However, our data either eliminate or are inconsistent with some proposed causes. We specifically examined three potential causes of marsh dieback in terms of consistency with the spatial pattern of dieback, the differential susceptibility of marsh species and their known stress tolerances, and the temporal sequence of dieback and recovery.

\section{Biotic Agents}

We found no evidence in support of a biotic agent as the primary cause of marsh dieback. Although potential fungal pathogens were isolated from $S$. alterniflora, infection usually occurs on previously stressed vegetation and is therefore unlikely to be an explanation by itself. Fungal or other pathogens also cannot explain the consistent local pattern of dieback. Fungal pathogens may have played a secondary role in plant mortality through interaction with an abiotic stress factor, but further experiments are required to test this possibility.

Outbreaks of insects or other herbivores were also ruled out as potential causes. This conclusion was based primarily on the spatial pattern and extent of dieback as well as the condition of dead and dying vegetation. Our observations specifically do not support the contention that dieback was caused by excessive grazing by the Littoraria irrorata (marsh periwinkle) (Bertness and Silliman, 2002). The data instead indicate that snails responded to the dieback and played an important role in rapid degradation of standing dead plants in some areas.

\section{Excessive Soil Waterlogging and Sulfide}

Although soil waterlogging and sulfide toxicity have been implicated in historical dieback of $S$. alterniflora, our data do not support this explanation with respect to acute marsh dieback. Historical records do not indicate that water levels were abnormally high in interior marshes during spring 2000 but that this was a period of unusually low water levels. Elevated sulfide concentrations were found in dieback marshes but may have occurred because death of the vegetation would stimulate sulfate reduction. In addition, we found no evidence of sulfide concentrations that exceeded the tolerance limits of $S$. alterniflora during the study period (June 2000 to September 2001) and generally found conditions that were typical of interior marshes. Also, this explanation does not account for the dieback of Spartina spp. and survival of other species that are known to be sensitive to sulfide (e.g., A. germinans) (McKee, 1993). Finally, sulfide concentrations remained elevated or even increased over time in areas where revegetation occurred. However, waterlogging and elevated sulfide in interior marshes may have increased the susceptibility of Spartina spp. to another stress factor that precipitated the dieback event.

\section{Drought and Low Water Levels}

The dieback event was coincident with an extreme drought condition, low river discharge, and low sea level. Drought, combined with less tidal flooding, may have decreased water availability directly, increased salinity by concentrating salts in the pore water, and/or caused oxidation and acidification of soils.

\section{Direct Lack of Water}

We found evidence of dry, cracked soils at a few sites, indicating that these marshes can become desiccated under certain conditions. However, most sites were flooded at the time of our 
surveys. Our data thus cannot eliminate the possibility that a direct lack of water caused plant mortality. However, greenhouse experiments were unable to duplicate this hypothesized effect on S. alterniflora, even when water was withheld for $30 \mathrm{~d}$ (R.R. Twilley and others, unpublished data).

Hypersalinity

We also found no evidence in support of hypersalinity as a cause of marsh dieback. Soil salinities measured at dieback sites from June 2000 to September 2001 were within the ecological range of $S$. alterniflora and well below the lethal limit for this species. However, the most convincing evidence against this hypothesis is the fact that a species ( $J$. roemerianus) with lower salt tolerance growing within $S$. alterniflora dieback areas not only survived the event but also showed little or no signs of stress. The differential salt tolerance of these species has been confirmed in controlled laboratory experiments (Mendelssohn and others, 2005).

Soil Acidification and Metal Toxicity

When saline sediments are aerated during drying, microbial oxidation of pyrite and sulfide generates sulfuric acid, which leads to soil acidification and ultimately to release of potentially toxic metals such as aluminum and iron. Our data are consistent with this explanation. Dieback sites had higher concentrations of pyrite and acid-extractable aluminum and iron than did reference marshes that did not die. Plants from dieback marshes also contained significantly higher ratios of aluminum and iron, indicating increased uptake of potentially toxic metals, than did those growing along nearby shorelines and in reference marshes where plant mortality was low. The subsequent decline of tissue metal ratios to control levels during vegetative recovery further substantiates this explanation. In addition, laboratory trials demonstrated that soils from dieback marshes acidified upon oxidation, whereas those from reference sites did not. The fact that salt marsh sediments accumulate more trace and heavy metals because of mineral input from rivers compared to those of intermediate and freshwater marshes with more organic substrates and that those salt marsh sediments also show greater decreases in $\mathrm{pH}$ upon oxidation is also consistent with the regional pattern of dieback primarily in saline marshes.

A fuller understanding of this acute dieback event and its consequences relative to historical dieback in Barataria-Terrebonne salt marshes is needed to aid in conservation and restoration efforts. Just as important are the implications of this event for global change models that focus mainly on sea-level rise as the dominant variable controlling vegetation patterns in coastal ecosystems (Day and others, 1993). Numerous studies of sea-level rise and potential impacts on wetland areas have been conducted along the Atlantic and gulf coasts (Day and others, 1993). Sealevel rise gradually increases submergence and salinity in coastal areas, and these effects are most pronounced in deltas and lagoons that are undergoing regional subsidence and/or human alterations (Day and others, 1993). The sudden dieback of salt marshes in Louisiana suggests another scenario in which periodic climatic extremes cause rapid, widespread mortality of vulnerable species.

Ecologists now recognize the importance of large, infrequent disturbances in shaping landscapes and structuring plant communities (Romme and others, 1998; Turner and Dale, 1998). Foster and others (1998) argue, for example, that such disturbances produce long-lasting changes in the physical and biological structure of forests that influence ecosystem functioning for decades or centuries. Large-scale, infrequent disturbances may also be so qualitatively different from small, frequent disturbances that the rates and patterns of recovery may differ (Romme and others, 1998). 
However, the fundamental characteristics of an ecosystem are usually not altered even by extreme events, since organisms have evolved in the presence of disturbance. Permanent changes typically occur only with multiple disturbances that together exceed the rate of recovery by organisms (Paine and others, 1998; McKee and Baldwin, 1999). Some dieback marshes have recovered naturally and will require no restoration. In other areas, $S$. alterniflora may ultimately be supplanted by other species such as A. germinans or J. roemerianus. At a minimum, there will be expansion of other species into areas formerly dominated by S. alterniflora. Lack of rapid revegetation and loss of soil structure in some dieback marshes could accelerate land loss. Even so, further monitoring of these areas will be necessary to determine the extent of permanent change.

The implications of this event for other coastal systems are unclear partly because the precise causal mechanism for the acute dieback in the Mississippi River deltaic plain is not known. Also, preexisting stress conditions may play a role in acute dieback, but how and to what degree is not currently understood. The Mississippi delta is perhaps an extreme case since it has been undergoing high rates of apparent sea-level rise ( 8.5 to $9.5 \mathrm{~mm} / \mathrm{yr}$ ) and marsh deterioration (Day and others, 1993). Nonetheless, the sudden dieback of $S$. alterniflora marshes in Louisiana suggests that large-scale changes in coastal vegetation may occur much more rapidly than current models predict and as a consequence of weather extremes acting in concert with sea-level fluctuations and preexisting soil conditions. Management plans usually do not take disturbance into account because of unfamiliarity or a belief that the disturbance cannot be managed (Dale and others, 1998). However, even if a disturbance cannot be controlled, the resilience and recovery of the system may be altered by management (Dale and others, 1998). Such considerations will become increasingly important as global climate changes and human pressures in the coastal zone grow.

\section{Acknowledgments}

The Saltwater Marsh Dieback (aka Brown Marsh phenomenon) was declared an emergency by Louisiana Governor Mike Foster in the form of Executive Proclamation \#55-MJF-2000 issued on October 23, 2000. In response, Congress allocated approximately three million dollars in funds through the National Atmospheric and Oceanic Administration to Louisiana Department of Natural Resources (LDNR) to examine causes and effects of the Brown Marsh phenonmenon. This investigation was funded by a grant from LDNR. Additional funding was provided by the Louisiana Sea Grant Program, USGS National Wetlands Research Center, and the Louisiana Governor's Office of Coastal Activities.

Field and laboratory assistance was provided by Andrea Anteau, Tommy McGinnis, and Lee Stanton. Plant and soil elemental analyses were conducted by the laboratories of Dr. Wayne Hudnell and Kurt Hutchinson of the Department of Agronomy, Louisiana State University.

\section{Cited Literature}

Adriano, D.C., 1986, Trace elements in the terrestrial environment: New York, Springer-Verlag, $533 \mathrm{p}$.

Bertness, M.D., and Silliman, B.R., 2002, A trophic cascade regulates salt marsh primary production: Proceedings of the National Academy of Sciences, v. 99, p. 10500-10505. 
Carlson, P.R., Yarbro, L.A., Courtney, F.X., Arnold, H., Leslie, D., Hughes, J., and Craft, N., 2001, Panhandle salt marsh mortality: a prelude to Louisiana brown marsh? [abs.]: Coastal Marsh Dieback: Extent, Causes, Consequences, and Remedies Conference Proceedings: Baton Rouge, La., p. 8.

Dale, V.H., Lugo, A.E., MacMahon, J.A., and Pickett, S.T.A., 1998, Ecosystem management in the context of large, infrequent disturbances: Ecosystems, v.1, p. 546-557.

Day, J.W., Conner, W.H., Costanza, R., Kemp, G.P., and Mendelssohn, I.A., 1993, Impacts of sea level rise on coastal systems with special emphasis on the Mississippi River deltaic plain, in Warrick, R.A., Barrow, E.M., and Wigley T.M.L., eds., Climate and Sea Level Change: Cambridge, Cambridge University Press, p. 276-296.

Feijtel, T.C., DeLaune, R.D., and Patrick, W.H., Jr, 1988a, Seasonal pore water dynamics in marshes of Barataria Basin, Louisiana: Soil Science Society of America Journal, v. 52, p. 59-67.

Feijtel, T.C., DeLaune, R.D., and Patrick, W.H., Jr, 1988b, Biogeochemical control on metal distribution and accumulation in Louisiana sediments: Journal of Environmental Quality, v. 17, p. 88-94.

Foster, D.R., Knight, D.H., and Franklin, J.F., 1998, Landscape patterns and legacies resulting from large, infrequent forest disturbances: Ecosystems, v. 1, p. 497-510.

Hester, M.W., 1995, Intraspecific variation in salt tolerance in Panicum hemitomon, Spartina patens, and Spartina alterniflora: population differentiation and investigations of underlying factors: Baton Rouge, Louisiana State University, Ph.D. Dissertation, 179 p.

Hester, M.W., Mendelssohn, I.A., and McKee, K.L., 1996, Intraspecific variation in salt tolerance and morphology in the coastal grass Spartina patens (Poaceae): American Journal of Botany, v. 83, p. 1521-1527.

Howarth, R.W., 1979, Pyrite: its rapid formation in a salt marsh and its importance in ecosystem metabolism: Science, v. 203, p. 49-51.

Jugsujinda, A., and Patrick, W.H., Jr, 1993, Evaluation of toxic conditions associated with oranging symptoms of rice in a flooded Oxisol in Sumatra, Indonesia: Plant and Soil, v. 152, p. 237-243.

Koch, M., Mendelssohn, I.A., and McKee, K.L., 1990, Mechanism for the hydrogen sulfideinduced growth limitation in wetland macrophytes: Limnology and Oceanography, v. 35, p. $399-408$.

McKee, K.L., 1993, Soil physicochemical patterns and mangrove species distribution: reciprocal effects?: Journal of Ecology, v. 81, p. 477-487.

McKee, K.L., and Baldwin, A.H., 1999, Disturbance regimes in North American wetlands, in Walker, L.R., ed., Ecosystems of Disturbed Ground, Ecosystems of the World 16: Amsterdam, Elsevier, p. 331-363.

McKee, K.L., Mendelssohn, I.A., and Hester, M.W., 1988, Reexamination of pore water sulfide concentrations and redox potentials near the aerial roots of Rhizophora mangle and Avicennia germinans: American Journal of Botany, v. 75, p. 1352-1359.

Mendelssohn, I.A., and McKee, K.L., 1988, Spartina alterniflora die-back in Louisiana: Timecourse investigation of soil waterlogging effects: Journal of Ecology, v. 76, p. 509-521. 
Mendelssohn, I.A., and Morris, J.T. 2000, Eco-physiological controls on the productivity of Spartina alterniflora Loisel., in Weinstein, M.P., and Kreeger, D.A., eds. Concepts and Controversies in Tidal Marsh Ecology: Dordrecht, Kluwer, p. 59-80.

Mendelssohn, I.A., McKee, K.L., and Hester, M.W., 2005, Brown marsh task II.1: Integrative approach to understanding the causes of salt marsh dieback-determination of salt marsh species tolerance limits to potential environmental stressors, final report to the Louisiana Department of Natural Resources, $83 \mathrm{p}$.

Mendelssohn, I.A., McKee, K. L., and Patrick, W.H., Jr, 1981, Oxygen deficiency in Spartina alterniflora roots: metabolic adaptation to anoxia: v. Science, 214, p. 439-441.

Mendelssohn, I.A., Turner, R.E., and McKee, K.L., 1983, Louisiana's eroding coastal zone: management alternatives: Journal of the Limnological Society of Southern Africa, v. 9, p. 6375.

Nordstrom, D.R., 1982, Aqueous pyrite oxidation and subsequent formation of secondary iron minerals, in Kittrick, and others, eds., Acid Sulfate Weathering: Madison, Soil Science Society of America Special Publication 10, p. 37-56.

Nyman, J.A., Burcham, A.K., Foret, J.D., Melancon, G., Michot, T.C., and Schmidhauser, T.J., 2001, Preliminary studies of brown marsh in a Chenier Plain, Spartina patens marsh [abs.]: Abstract, Coastal Marsh Dieback: Extent, Causes, Consequences, and Remedies Conference Proceedings: Baton Rouge, La., p. 18.

Paine, R.T., Tegner, M.J., and Johnson, E.A., 1998, Compounded perturbations yield ecological surprises: Ecosystems, v. 1, p. 535-545.

Philander, S.G.H., 1990, El Niño, La Niña and the southern oscillation: San Diego, Cal.USA, Academic, 289 p..

Romme, W.H., Everham, E.H., Frelich, L.E., Moritz, M.A., and Sparks, R.E., 1998, Are large, infrequent disturbance qualitatively different from small, frequent disturbances?: Ecosystems, v. 1, p. 524-534.

SAS Institute Inc., 2003, JMP Statistics and Graphics Guide, Version 5.0.1. Statistical Analysis System, Cary, N.C., 249 p.

Scruton, F.P., 1960, Delta building and the deltaic sequence, in Shepard, F.P, Phlegar, F.B., and van Andel, T.H., eds., Recent Sediments, Northwest Gulf of Mexico: Tulsa, Okla., American Association of Petroleum Geologists Symposium, p. 82-102.

Smith, W.G., 1970, Spartina "die -back" in Louisiana marshlands: Coastal Studies Bulletin No. 5, Baton Rouge, Louisiana State University, p. 89-96.

Turner, M.G., and Dale, V.H., 1998, Comparing large, infreqent disturbances, what have we learned?: Ecosystems, v. 1, p. 493-496.

Webb, E.C., Mendelssohn, I.A., and Wilsey, B.J., 1995, Causes for vegetation dieback in a Louisiana salt marsh: A bioassay approach: Aquatic Botany, v. 51, p. 281-289.

Wilsey, B.J., McKee, K.L., and Mendelssohn, I.A., 1992, Effects of increased elevation and macro- and micronutrient additions on Spartina alterniflora transplant success in saltmarsh dieback areas in Louisiana: Environmental Management, v. 16, p. 505-511. 